\title{
A COMPAR ATIVE ANALYSIS OF SOME OF THE IMMEDIATE ENVIRONMENTAL EFFECTS AT HIROSHIMA AND NAGASAKI
}

By

Clayton S. White,

I. G. Bowen, and

Donald R. Richmond

Approved By: L. J. Deal

Chief

Civil Effects Branch

Lovelace Foundation For Medical Education and Research

and

Division of Biology and Medicine, USAEC

Presented before the Eighth Annual Meeting of the Health Physics Society

New York City, June 11, 1963. 


\section{DISCLAIMER}

This report was prepared as an account of work sponsored by an agency of the United States Government. Neither the United States Government nor any agency Thereof, nor any of their employees, makes any warranty, express or implied, or assumes any legal liability or responsibility for the accuracy, completeness, or usefulness of any information, apparatus, product, or process disclosed, or represents that its use would not infringe privately owned rights. Reference herein to any specific commercial product, process, or service by trade name, trademark, manufacturer, or otherwise does not necessarily constitute or imply its endorsement, recommendation, or favoring by the United States Government or any agency thereof. The views and opinions of authors expressed herein do not necessarily state or reflect those of the United States Government or any agency thereof. 


\section{DISCLAIMER}

Portions of this document may be illegible in electronic image products. Images are produced from the best available original document. 


\title{
ABSTRACT
}

\begin{abstract}
The problem a reas of concern to those who would establish a quantitative relation between biologic response and the more immediate environmental variations caused by nuclear explosions were defined. The scope of blast and shock biology was set forth and a selective summary of current knowledge regarding biological blast effects was presented. Tentative criteria useful in assessing the hazards of some of the major nuclear effects were noted. Following elucidation of the range-yield-effects relationship applicable to high-yield explosions generally, the criteria were applied specifically to a $20-\mathrm{kt}$ yield burst at heights assumed to apply to the Hiroshima and Nagasaki explosions. The procedure, establishing the range-effect relationships for the two Japanese cities, was carried out through use of the free-field scaling laws and a mathematical model allowing scaling of translational effects for both debris and man. Thus an attempt was made to predict the ranges inside which the potential existed for producing specified levels of biological damage. For each of the predicted ranges, values for overpressure, thermal and initial nuclear radiations along with translational velocities for man and glass fragments were computed to allow a more balanced appreciation of all the effects parameters that pose a hazard to $\mathrm{man}$.

The implications of the free-field range-effects data in interpreting some of the immediate effects at Hiroshima and Nagasaki were explored and discussed. Though the over-all analytical approach followed was thought to be useful and sound, the tentative nature of many of the numerical data presented was emphasized. Thus those numbers employed representing best current estimates as well as values arbitrarily assigned were all noted to be subject to future refinement as new information expands the understanding of nuclear phenomenology and the consequences of exposure thereto.

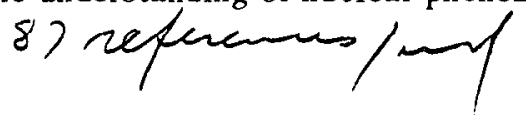





\section{CONTENTS}

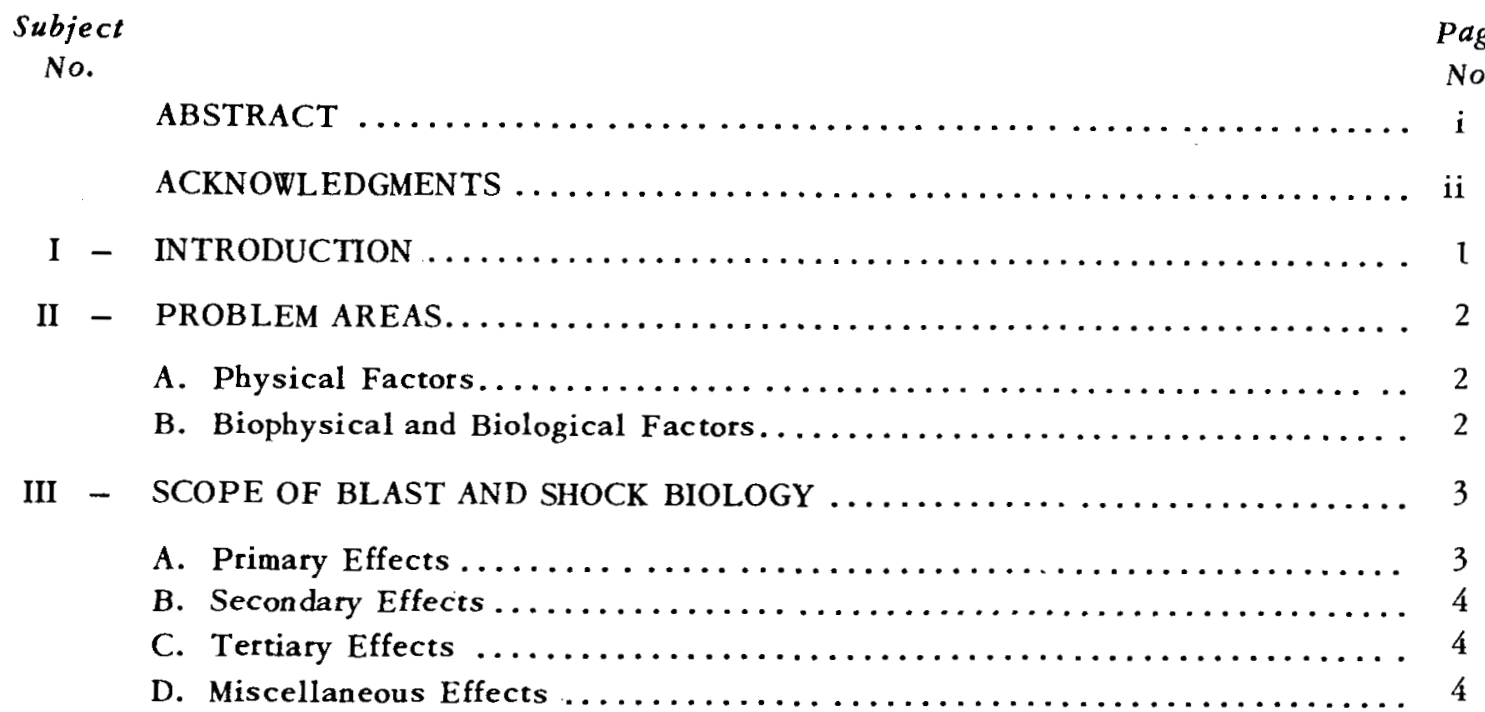

IV - SELECTED BLAST EFFECTS DATA AND SOME TENTATTVE

CRITERIA FOR HUMAN TOLERANCE ................. 4

A. Primary Blast Effects $\ldots \ldots \ldots \ldots \ldots \ldots \ldots \ldots \ldots \ldots \ldots \ldots \ldots \ldots \ldots \ldots$

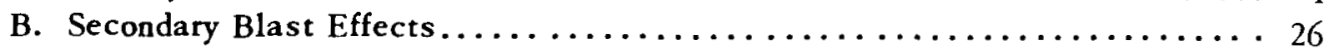

C. Tertiary Blast Effects $\ldots \ldots \ldots \ldots \ldots \ldots \ldots \ldots \ldots \ldots \ldots \ldots \ldots \ldots \ldots$

$\mathrm{V}$ - THE FREE-FIELD RANGE-YIELD-EFFECTS RELATIONSHIP .......... 31

VI - THE FREE-FIELD RANGE-EFFECTS DATA FOR HIROSHIMA

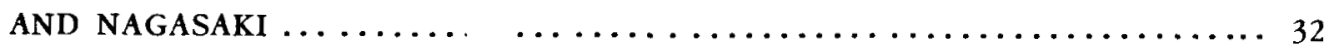

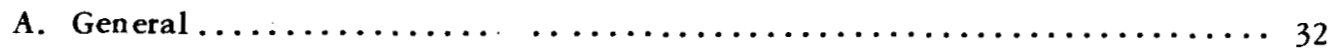

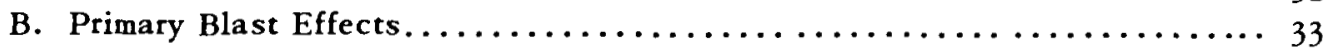

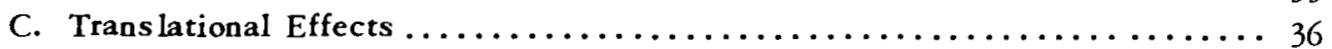

D. Summary of Comparative Free-Field Effects Data .............. 43

VII - IMPLICATIONS OF THE FREE-FIELD RANGE-EFFECTS DATA..........48

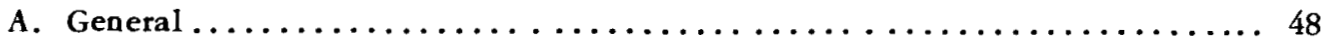

B. Specific................................. 50

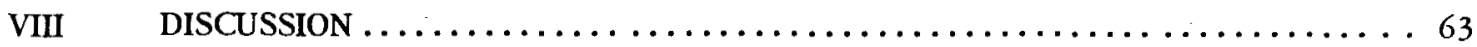

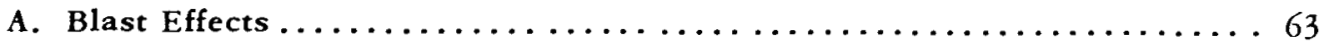

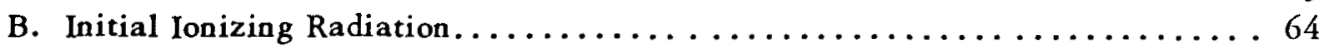

C. Comparative Effects Data Summary ..................... 66

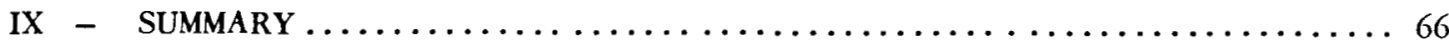




\section{TABLES}

No. 1 Relation Between "Sharp"-Rising Overpressure and Pulse Duration

Required for 50 -Per Cent Lethality .................... 6

No. 2 Tentative Estimate of Pressure-Duration Relationship for 50-Per

Cent Letha lity in Adult Humans $(70 \mathrm{~kg}) \ldots \ldots \ldots \ldots \ldots \ldots \ldots \ldots \ldots \ldots \ldots \ldots$

No. 3 Tentative Criteria for Primary Blast Etfects .................. 7

No. 4 Results of the Probit Analysis Relating Lethality to Overpressure ........ 8

No. 5 Mortality Data for Guinea Pigs for "Fast"-Rising, "Long"-Duration

Shock Tube-Produced Overpressures when the Incident and

Reflected Overpressures are Applied in Two Steps............... 12

No. 6 Effects on Dogs of Long Duration Overpressure Applied at Different Rates . . . 16

No. 7 The Occurrence of Orbital Fractures in Dogs as Related to the Peak Pressure and the Time to Peak Pressure....................... 19

No. 8 Tentative Criteria for Secondary Blast Effects $\ldots \ldots \ldots \ldots \ldots \ldots \ldots \ldots \ldots \ldots$

No. 9 Tentative Criteria for Secondary Blast Effects ................. 27

No. 10 Tentative Criteria for Tertiary Blast Effects.................. 30

No. 11 The Ranges of Impact Velocities Associated with Experimental Fracture of the Human Skull. ......................... 30

No. 12 Range for Specified Primary Blast Hazards and Associated Free-Field Effects Parameters Scaled for 20-kt Yield at Hiroshima Burst Height of $1988 \mathrm{ft}(606 \mathrm{~meters})$ above Sea-Level Terrain .................. 34

No. 13 Range for Specified Primary Blast Hazards and Associated Free-Field Effects Parameters Scaled for 20-kt Yield at Nagasaki Burst Height of $1575 \mathrm{ft}$ (480 meters) above Sea-Level Terra in ................... 35

No. 14 Range for Specified Secondary Blast Hazards and Associated Free-Field Effects Parameters Scaled for 20-kt Yield at Hiroshima Burst Height of $1988 \mathrm{ft}$ (606 meters) above Sea-Level Terrain ......................... 39

No. 15 Range for Specified Secondary Blast Hazards and Associated Free-Field Effects Parameters Scaled for 20-kt Yield at Nagasaki Burst Height of $1575 \mathrm{ft}$ ( 480 meters) above Sea-Level Terrain . . . . . . . . . . . . . . . 39 


\section{TABLES (Continued)}

No. 16 Range for Specified Secondary Blast Hazards and Associated Free-Field Effects Parameters - $20 \mathrm{kt}$ Yield at Hiroshima Burst Height of $1988 \mathrm{ft}(606$ meters) above Sea-Level Terrain . . . . . . . . . . . . . .

No. 17 Range for Specified Secondary Blast Hazards and Associated Free-Field Effects Parameters - $20 \mathrm{kt}$ Yield at Nagasaki Burst Height of $1575 \mathrm{ft}$ (480 meters) above Sea-Level Terrain

No. 18

Range for Specified Tertiary Blast Hazards and Associated Free-Field Effects Parameters - $20 \mathrm{kt}$ Yield at Hiroshima Burst Height of $1988 \mathrm{ft}(606$ meters) above Sea-Level Terrain . . . . . . . . . . . . . . . . . . .

No. 19 Range for Specified Tertiary Blast Hazards and Associated Free-Field Effects Parameters - $20 \mathrm{kt}$ Yield at Nagasaki Burst Height of

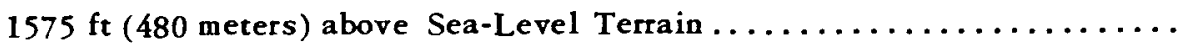

No. 20 Comparative Biological Effects as a Function of Range for a $20 \mathrm{kt}$ Yield Scaled for Hiroshima Burst Height of $1988 \mathrm{ft}$ (606 meters) above Sea-Level Terrain

No. 21 Comparative Biological Effects as a Function of Range for a 20-kt Yield Scaled for Nagasaki Burst Height of $1575 \mathrm{ft}$ (480 meters) above

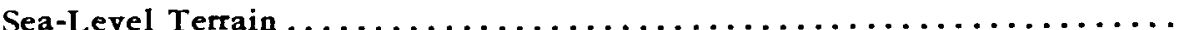

No. 22 Ranges Inside which Available Data Indicate the Potential for Serious Primary Blast Injury for the Japanese Explosions Along with

No. 23 Ranges Inside which Available Data Indicate the Potential for Producing Wounds from Secondary Glass Missiles Traveling $10 \mathrm{ft}$ Energized by the Japanese Explosions Along with Related Effects Data .....

No. 24

Ranges Inside which Available Data Indicate the Potential for Producing Tertiary Blast Injury from Impact after $10 \mathrm{ft}$ of Travel for the Japanese Explosions Along with Related Effects Data

No. 25

Early and Delayed Lethality for Bankers' Club 250 Meters (0.155 Mi)

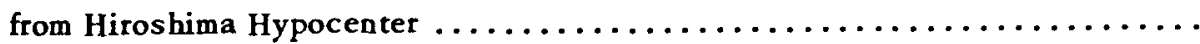

No. 26

Overall (Early Plus Delayed) and Delayed Lethality for Bankers' Club 250

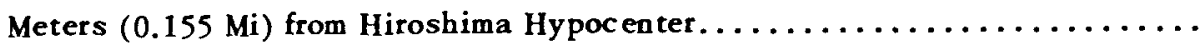

No. 27

Lethality-Time Data for Hijiyama School 750 Meters (0.466 Mi) from Hiroshima Hypocenter, Ref. NP-3037, Vol. II, Page 95

No. 28

Survival and Lethality Data for Chinzei School 500 Meters (0.31 Mi) from Nagasaki Hypocenter . . . . . . . . . . . . . . . . . . . 57

No. 29

Incidence of Single and Multiple Type Injuries

No. 30

Number of Single and Multiple Type Injuries by Source

No. 31

Totals for Multiple Injury Data taken from Tables 29 and 30 after Oughterson and Warren (Continued on following page) 


\section{TABLES (Continued)}

No. 31 (Con tinued)

Part I - Summary Number of Individuals among Twenty-Day-Survivors at Hiroshima and Nagasaki Exhibiting Single and

Multiple Injuries . . . . . . . . . . . . . . . . 61

Part II - Summary Number of Single and Multiple Type Injuries among Twenty-Day-Survivors

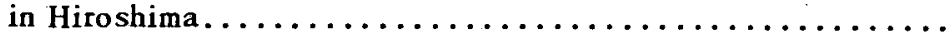




\section{ILLUSTR ATIONS}

Figure

No.

No. 1

Physically Oriented Problem Areas Relevant to Biological Effects of Nuclear Explosions . . . . . . . . . . . . . . . . . . . . . . .

No. 2 Biomedically Oriented Problem Areas Relevant to Biological Effects

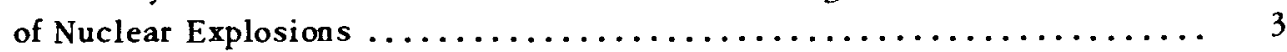

No. 3 Overpressure for 50 Per Cent Lethality as a Function of Duration ..........

No. 4 Relation between Body Weight and Fast-Rising Overpressures of 400 Milliseconds Duration Needed to Produce 50 Per Cent Mortality........

No. 5 The Overpressure Duration Relationship Calculated for 1, 50 and 99 Per Cent

Lethality for the $70 \mathrm{~kg}$ Mammal.........................

No. 6 Maximal Incident and Reflected Overpressures Associated with 50 Per Cent Lethality in Guinea Pigs as a Function of Exposure Geometry ......... 8

No. 7 Pressure-Time Records Associated with the Shallow Chamber............ 9

No. 8 Pressure-Time Records Associated with the Deep Chamber............ 9

No. 9 Pressure-Time Records Associated with the Deep-With-Offset Chamber...... 10

No. 10 Wave Forms Illustrating Almost Instantaneous and Stepwise Increases in Overpressure ................................ 12

No. 11 Tolerance of Animals to Overpressures Applied in Two Steps ............ 13

No. 12 Mortality Variations for Animals Exposed Against and At Indicated Distances from the End-Plate Closing the End of a Shock Tube. Incident and Reflected Overpressures Varied from 16.6 to 18.7 and 48 to 55 Psi, Respectively, and Endured for 6 to 8 Seconds...........

No. 13 Gross Biological Response Following Exposure of Dogs to "Slowly" Rising Overpressures of "Long" Duration ...................

No. 14 The Relation Between Orbital Fractures, Exposure Geometry and Pressure-Time Parameters.......................... 17

No. 15 Idealized Atypical Pressure-Time Curve......................... 19

No. 16 Cumulative Per Cent of Mortally Wounded Animals Dying Over a Two Hour Period from Exposure to "Sharp"'-Rising Overpressures of $3-4$ Milliseconds Duration ........................ 20 


\section{ILLUSTRATIONS (Continued)}

Figure

No.

No. 18 Lethality-Time Data for Guinea Pig for "Long"-Duration "Fast"'-Rising Overpressures of Indicated Values $\ldots \ldots \ldots \ldots \ldots \ldots \ldots \ldots \ldots \ldots \ldots \ldots \ldots \ldots$

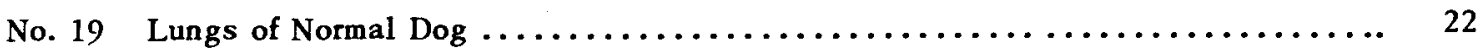

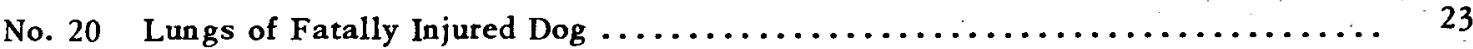

No. 21 Aveolar Venous Fistula ................................. 24

No. 22 Air Embolism of Coronary Arteries of a Dog Fatally Injured by Blast ........ 25

No. 23 Probability of Penetration of Glass Fragments into the Abdomen of a Dog as a Function of Missile Mass and Impact Velocity ................. 26

No. 24 Average Lethality vs Time Observed During $v_{50}$ Studies............... 28

No. 25 Impact Velocity Associated with 50 Per Cent Mortality as a Function of Average Body Weight $\ldots \ldots \ldots \ldots \ldots \ldots \ldots \ldots \ldots \ldots \ldots \ldots \ldots \ldots$

No. 26 Comparative-Effects Data Showing Ranges Inside which Indicated Biological Responses may occur for Sea-Level Surface Bursts...........

No. 27 Relationship Between Maximum Overpressure and Initial Nuclear Radiation for Surface Burst at Sea-Level Ambient Pressure . . . . . . . . . .

No. 28

Range-Effect Relationship for Indicated Primary Blast Damage

20-kt Yield at Hiroshima Burst Height of $1988 \mathrm{Ft}$ (606 Meters)

above Sea-Level Terrain

No. 29 Range-Effect Relationship for Indicated Primary Blast Damage - 20-kt Yield at Nagasaki Burst Height of $1575 \mathrm{ft}$ ( 480 meters) above Sea-Level

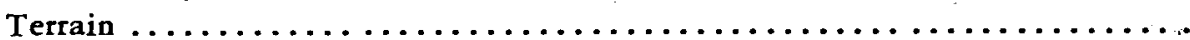

No. 30 Predicted Maximum Velocity as a Function of Acceleration Coefficient ( $a$ ) and Shock Overpressure computed for $W=20 \mathrm{kt}, \mathrm{P}_{0}=14.7 \mathrm{psi}$, and $c_{0}=1117$ $\mathrm{ft} / \mathrm{sec}$. For other conditions, use:

$a_{1}=a\left(\frac{1117}{\mathrm{c}_{0}}\right)^{2}\left(\frac{\mathrm{p}_{0}}{14.7}\right)^{2 / 3}\left(\frac{\mathrm{W}}{20}\right)^{1 / 3} \quad \nabla_{\mathrm{m}}=\left(\mathrm{v}_{\mathrm{m}}\right)_{1} \frac{\mathrm{c}_{0}}{1117}$

No. 31 Predicted Displacement at Maximum Velocity as a Function of Acceleration Coefficient $(\alpha)$ and Shock Overpressure computed for $\mathrm{W}=20 \mathrm{kt}, \mathrm{p}_{0}=14.7 \mathrm{psi}$, and $\mathrm{c}_{0}=1117 \mathrm{ft} / \mathrm{sec}$. For other conditions, use: $a_{1}=a\left(\frac{1117}{c_{0}}\right)^{2}\left(\frac{\mathrm{p}_{0}}{14.7}\right)^{2 / 3}\left(\frac{\mathrm{w}}{20}\right)^{1 / 3} \quad \mathrm{~d}_{\mathrm{m}}=\left(\mathrm{d}_{\mathrm{m}}\right)_{1}\left(\frac{14.7 \mathrm{~W}}{\mathrm{p}_{0}{ }^{20}}\right)^{1 / 3}$

No. 32 The Velocity-Distance-Pressure Relationship computed for Man - Yield 20 kt... 38

No. 33 The Velocity-Distance-Pressure Relationship computed for Window

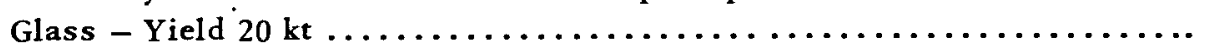

No. 34 The Velocity-Range Relationship for Translational Effects 20 -kt Yield at Hiroshima Burst Height of $1988 \mathrm{ft}(606$ meters) $\ldots \ldots \ldots \ldots \ldots \ldots \ldots \ldots \ldots$

No. 35 The Velocity-Range Relationship for Translational Effects 20-kt Yield at Nagasaki Burst Height of $1575 \mathrm{ft}$ ( 480 meters) $\ldots \ldots \ldots \ldots \ldots \ldots \ldots \ldots$ 


\section{ILLUSTR ATIONS (Continued)}

$\begin{array}{lll}\text { Figure Page } & \text { Page }\end{array}$

No.

No.

No. 36 Incidence of Burns by Distance and Shielding at Hiroshima

Figure 3.22 from Oughterson and Warren $\ldots \ldots \ldots \ldots \ldots \ldots \ldots \ldots \ldots \ldots \ldots$

No. 37 Incidence of Bums by Distance and Shielding at Nagasaki

Figure 3.23 from Oughterson and Warren $\ldots \ldots \ldots \ldots \ldots \ldots \ldots \ldots \ldots \ldots \ldots$

No. 38 Incidence of Blast Injuries and Burns by Distance at Hiroshima

probable incidence in the inner most zones, assuming that all those

killed were injured by blast and radiant heat. Figure 3.20

from Oughterson and Warren $\ldots \ldots \ldots \ldots \ldots \ldots \ldots \ldots \ldots \ldots \ldots \ldots \ldots$

No. 39 Incidence of Blast Injuries and Burns by Distance at Nagasaki

probable incidence in the inner most zones, assuming that all those

killed were injured by blast and radiant heat. Figure 3.21

from Oughterson and Warren $\ldots \ldots \ldots \ldots \ldots \ldots \ldots \ldots \ldots \ldots \ldots \ldots \ldots \ldots$

No. 40 Early and Delayed Lethality for Bankers' Club (250 meters) at Hiroshima ..... 54

No. 41 Overall (Early Plus Delayed) and Delayed Lethality for Bankers' Club

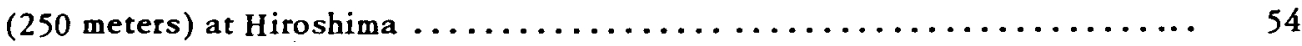

No. 42 Delayed Lethality for Bankers' Club (250 meters) at Hiroshima .......... 55

No. 43 Typical Lethality-Time Curves .......................... 55

No. 44 Temperature-Time Relationship producing Indicated Degree of Hot-Air

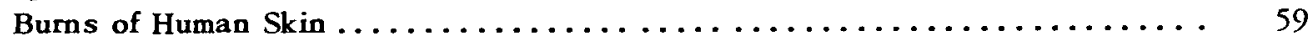

No. 45 Percentage of Survivors as a Function of Range from Ground Zero

(Hiroshima)................................. 62

No. 46 Dose-Range Relation for Initial Nuclear Radiation at Hiroshima .......... 65

No. 47 Dose-Range Relation for Initial Nuclear Radiation at Nagasaki........... 65

No. 48 Comparative Range-Effects Relationships for Hiroshima - 20-kt Burst at $1988 \mathrm{ft}(606 \mathrm{~meters})$ above Sea-Level Terrain . . . . . . . . . . . . . . . . 67

No. 49 Comparative Range-Effects Relationships for Nagasaki - 20-kt Burst at $1575 \mathrm{ft}$ (480 meters) above Sea-Level Terrain .................. 


\section{A COMPARATIVE ANALYSIS OF SOME OF THE IMMEDIATE ENVIRONMENTAL EFFECTS \\ AT HIROSHIMA AND NAGASAKI*}

by

CLAYTON S. WHITE, I. G. BOWEN

AND DONALD R. RICHMOND

\section{INTRODUCTION}

Under the sponsorship of the Division of Biology and Medicine of the Atomic Energy Commission and the Defense Atomic Support Agency of the Department of Defense, it has been possible for the Lovelace Foundation to pursue investigations of the biological effects of air blast and to carry out studies of selected aspects of weapons effects on a continuing basis since 1951. While much of the work has been concerned with the pathophysiology of blast damage, it has also dealt with relevant physical and biophysical factors in sufficient depth to allow the findings to be applicable generally to portions of environmental and industrial medicine on the one hand and specifically to aid the quantitative assessment of the more immediate effects of conventional and nuclear explosions on the other. It is of course the latter that is germane to a colloquium dealing with some of the biomedical consequences of the nuclear detonations in Japan. Since there is neither broad appreciation of the complex nature of the tasks involved nor wide understanding of the more recent findings in blast biology, an attempt will be made in this presentation to cover six topics to exemplify some of the past and current activities under way to arrive at a more balanced understanding of weapons effects; namely,

1. Attention will be directed to the problem areas which challenge those who desire an adequate grasp of the environmental variations that follow nuclear explosions and the biological consequences of exposure thereto.

2. The scope of blast biology will be defined.

3. Selected quantitative data will be presented to illustrate the current state of knowledge in blast biology and the tentative estimates of human tolerance that are forthcoming.

4. The free-field range-yield-effects relationship will be noted over a wide variation in explosive yields.

5. The free-field range-effects data for the Hiroshima and Nagasaki explosions will be set forth and the current, though tentative, biological effects criteria will be applied.

6. The implications of the range-effects data applicable to primary, secondary and tertiary blast injury will be explored with respect to interpreting the immediate effects in Hiroshima and Nagasaki and for nuclear explosions generally.

* This study, carried out at the Lovelace Foundation for Medical Education and Research, Albuquerque, New Mexico was supported by Contract No. AT(29-1)-1242 with the Division of Biology and Medicine of the U. S. Atomic Energy Commission. 


\section{PROBLEM AREAS}

In those special portions of environmental medicine that apply to the effects of high-yield explosions, it is desirable to establish a quantitative relationship between the magnitude of the environmental variations involved and the degree of damage produced, or likely to be produced, in man. To do this adequately, as has been pointed out elsewhere, 1.3 one must become concerned with at least three physically and three biologically oriented problem areas as noted in Figures 1 and 2 , respectively.

\section{A. PHYSICAL FACTORS}

On the physical side, these encompass first the energy source and the relevant fundamental principles underlying the range-yield relationship for each of the major effects that occur over reasonably flat terrain and in the absence of buildings and other sources of obstruction. Though the free-field scaling of effects is subject to variations due just to yield and range, there are other uncertainities of considerable importance; namely, weapon design, burst conditions, terrain and weather, to mention four. ${ }^{4-6}$

Figure 1

Physically oriented problem areas relevant to biological

effects of nuclear

explosions.

\section{ATTENUATION AND/OR AUGMENTATION}

(Modification of Free-Field Phenomena by Geometric Conditions of Exposure) "GEOMETRIC" SCALING

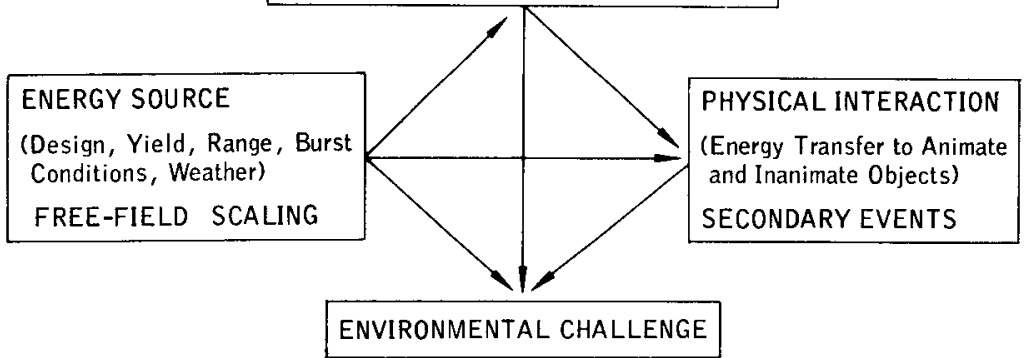

Secondly, all the free-field phenomena are potentially subject to modifications by the conditions or geometry of exposure; i.e., they may be augmented, attenuated or remain unchanged 4-18 and "geometric," in addition to free-field, scaling of effects parameters becomes necessary. Involved here are such things as pressure reflections, the scatter of thermal and ionizing radiations, neutron-induced activity, the behavior of various materials as radiation and thermal shields, and the increase or decrease of blast pressures and winds as they spill through various openings into structures of a variety of shapes and volumes. Thus what may happen inside and outside a structure exposed near a nuclear detonation may, depending upon a myriad of details, be nearly the same or very different indeed.

Third, physical interaction may occur whereby energy is transferred to animate as well as inanimate objects and translational effects ensue, whether the latter involve debris or man. These secondary events, along with "geometric" and free-field scaling, all, more often than not, must be combined to allow definition of the challenge to a biological target as indicated by the arrows in Figure 1; in toto, they spell out the "skin dose," if you will.

\section{B. BIOPHYSICAL AND BIOLOGICAL FACTORS}

Figure 2 notes in brief the more biologically oriented problem areas. First, biophysical interactions transpire. These encompass energy dissipation by and within biological targets and an 
adequate grasp of these events is fundamental in understanding the etiologic mechanisms of biologic response, the second matter of interest here. Involved are the major medical syndromes for isolated individual effects and for the little understood response to combined injury. However, the related quantitative data are basic to hazards assessment; namely, to saying what degree of a given environmental variation is safe, is associated with a decrement in performance, casualty production and with low, intermediate and high levels of lethality.

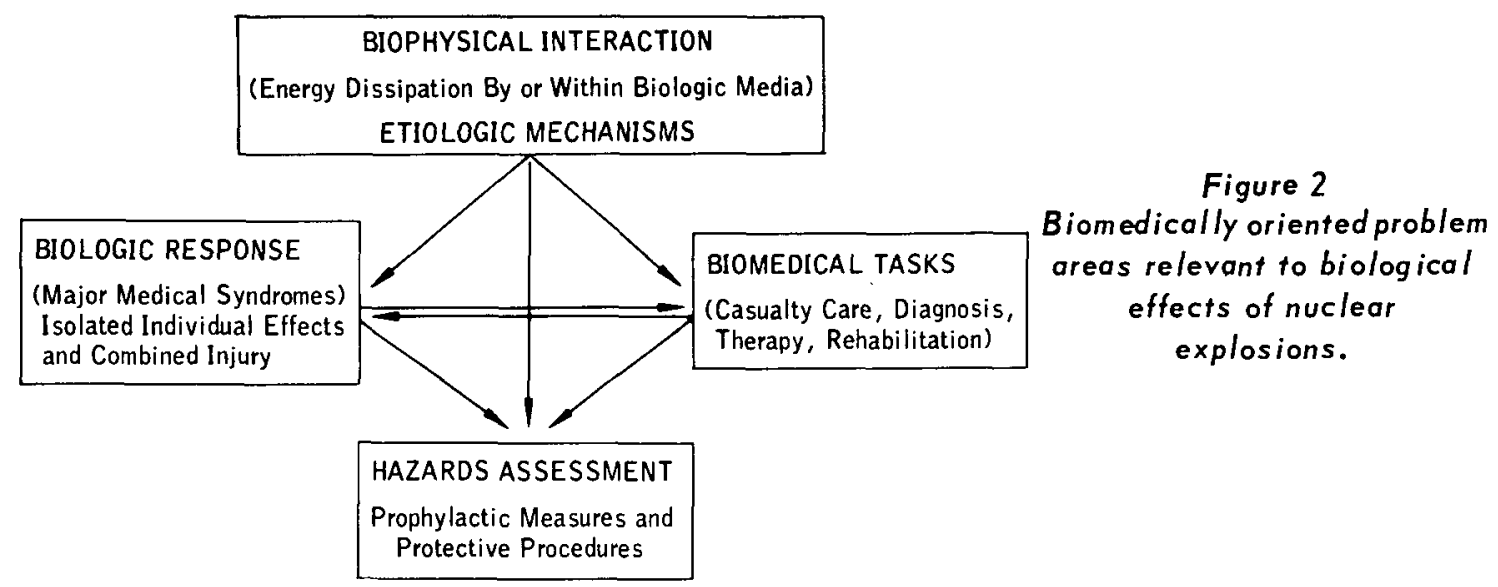

Third, and closely related, are the medical tasks of diagnosis, therapy, casualty care, recognition of early and long term sequelae, rehabilitation and the important matters of conceiving effective prophylactic measures and procedures.

In summary then, those who would understand the biologic challenge of nuclear detonations must work to complete the quantitative fabric needed to encompass and adequately interrelate all the problem areas in Figures 1 and 2. Admittedly, many complexities are involved and much needed information is simply not at hand. Through much more is now known than in the past, a continued effort both on the empirical front and the conceptual frontier is required if one is to properly relate hazards assessment with a conventional or a nuclear explosive source.

It will be well now to define the scope of blast and shock biology and to discuss the subject in a selective way to illustrate some of the progress that has been made in filling in the recognized problem areas for one of the major immediate effects of nuclear explosions.

\section{SCOPE OF BLAST AND SHOCK BIOLOGY}

Through Zuckerman ${ }^{19}$ in the early 1940's set forth a complete categorization of biological blast effects applicable to conventional explosives, a simplified, though arbitrary, definition of the scope of what has come to be called blast and shock biology has been employed as follows: $1,3,6-8,10,20.23$

A. PRIMARY EFFECTS include damage associated with exposure to variations in environmental pressure which emanate radially from an explosive source. 
B. SECONDARY EFFECTS are those resulting from the impact of debris energized by blast pressures, wind, ground shock and sometimes gravity. The wounds produced may be penetrating or nonpenetrating in character.

C. TERTIARY EFFECTS occur as a consequence of gross translation of the body mostly by blast pressures and winds, but ground shock and gravity may be contributing factors. Damage may be due to dynamic accelerative or decelerative loading or a combination of both.

D. MISCELLANEOUS EFFECTS encompass potential hazards from exposure to dust, ${ }^{24,25}$ to blast-induced fires ${ }^{4-6}, 26$ and to non-line-of-site thermal phenomena ${ }^{8-10,20-22,27-29}$ including hot gases, dust and other debris. Though these are important, they will not be dealt with in any detail here.

\section{SELECTED BLAST - EFFECTS DATA AND SOME TENTATIVE CRITERIA FOR HUMAN TOLERANCE}

Over the past decade, progress has been made in relating blast-induced environmental variations to biological response, and tentative - though incomplete - estima tes for assessing human hazards have been forthcoming. ${ }^{7}$ 20-23, 30-37 To illustrate the kind and character of data now available, a selective summary will be presented below.

\section{A. PRIMARY BLAST EFFECTS}

Regarding tolerance to environmental pressure variations produced by explosive events, it is now necessary to distinguish between exposure to typical and atypical wave forms and to grasp the highly hazardous nature of exposure to blast-induced overpressures.

\section{Typical or Classical Pulses of Overpressure}

For typical wave forms - those rising to a maximum almost instantaneously and decaying exponentially with time - tolerance of the mammal is governed by the magnitude and the duration of the pulse and varies generally with animal size.

\section{a. The Pressure-Duration Relationship}

For example, consider the data of Richmond, et al., ${ }^{30,34-37}$ graphically portrayed in Figure 3. The figure summarizes interspecies studies involving 2974 animals to date exposed to overpressures produced by specially designed shock tubes and small charges of high explosive to determine the maximal "sharp"-rising overpressure - the $\mathrm{P}_{50}$ - associated with 50-per cent lethality in 24 hours. The data, illustrating the pressure-duration relationship for "clean" wave forms, show that:

(1) There is a critical duration of the overpressure for each species shorter than which the lethal pressure rises significantly and longer than which only the maximal overpressure correlates with the specified level of damage.

(2) The critical duration is a function of animal size.

(3) Extrapolation of the data to mammals of various weights involves a spectrum of possibilities; i.e., for the $70-\mathrm{kg}$ mammal, the $\mathrm{P}_{50}$ will be relatively high, intermediate or low depending upon whether the pulse duration is short, intermediate or long, respectively. 


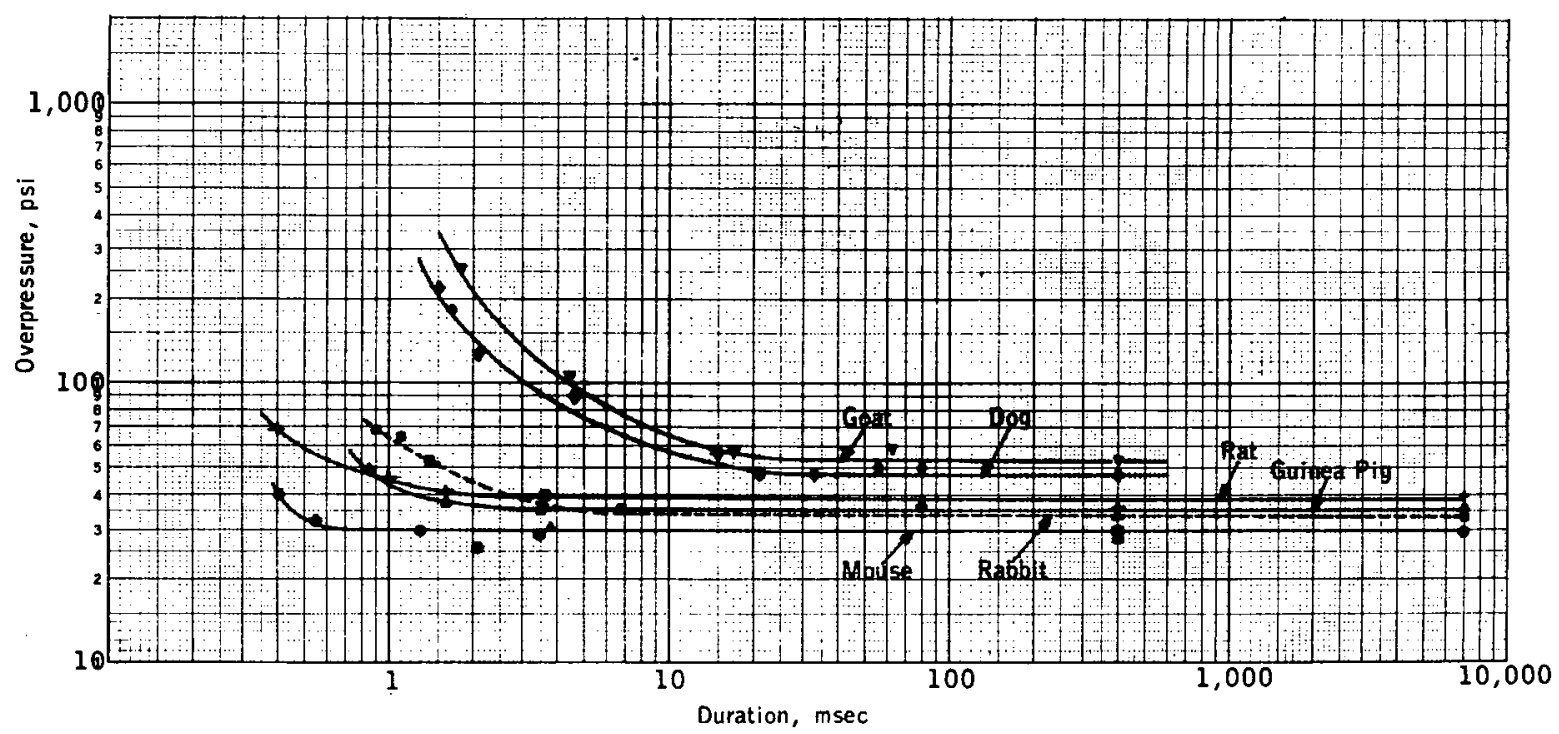

Figure 3 - Overpressure for $50 \%$ lethality as a function of duration.

b. The 400-Msec Study and Estimates for the 70-kg Mammal

The regression curve of Richmond et al. ${ }^{34}$ for the $\mathrm{P}_{50}$ figures applicable to six species of animals exposed to "fast"-rising overpressures of "long" duration (400 msec) is shown in Figure 4. Extrapolation of the data gives a value of $50.5 \mathrm{psi}$ for the $70-\mathrm{kg}$ mammal. In round figures, Table $\mathrm{I}$ shows the "smoothed" in terspecies estimates for the $\mathrm{P}_{50}$ applicable to ideal wave forms of durations less than $400 \mathrm{msec}$ with an extrapolation to the $70-\mathrm{kg}$ mammal. ${ }^{37}$ Figure 5 graphically presents the latter alcng with the calculated curves for pressure-duration relationship referable to lethality at the one and 99-per cent levels. ${ }^{97}$ It is interesting and important to note that the $P_{50}$ 's estimated for the $70-\mathrm{kg}$ mammal vary from 52 to $431 \mathrm{psi}$ and that the difference depends entirely upon variations in the duration of the pulse. It is of course more than a coincidence that the higher figures are consistent with findings and estimates of others based upon data obtained with conventional explosives. 3 8-4a

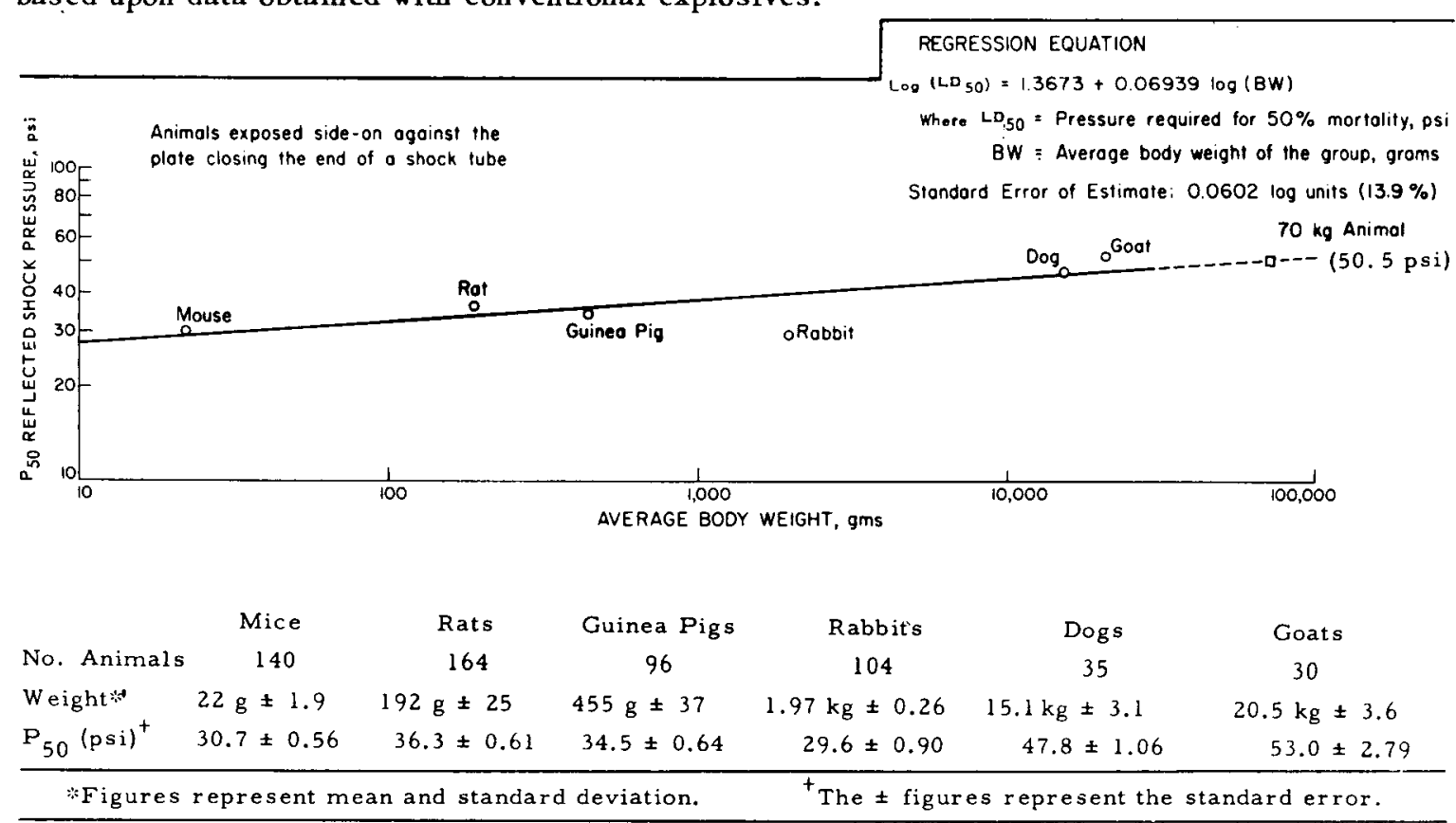

Figure 4-Relation between body weight and fast-rising overpressures of 400 -msec duration needed to produce $50 \%$ mortality. 
TABLE 1

RELATION BETWEEN "SHARP"-RISING OVER PRESSURE AND PULSE DURATION REQUIRED FOR 50\% LETHALITY

\begin{tabular}{|c|c|c|c|c|c|c|c|c|}
\hline \multirow{2}{*}{ SPECIES } & \multirow{2}{*}{$\begin{array}{l}\text { MEAN BODY } \\
\text { WEIGHT }\end{array}$} & \multicolumn{7}{|c|}{ LD $_{50}$ PRESSURES IN psi* } \\
\hline & & Duration, msec & 400 & 60 & 30 & 10 & 5 & 3 \\
\hline Mouse & $22.00 \mathrm{~g}$ & & 29 & 29 & 29 & 29 & 29 & 29 \\
\hline Rat & $192.00 \mathrm{~g}$ & & 36 & 36 & 36 & 36 & 36 & 36 \\
\hline Guinoo pig & $445.00 \mathrm{~g}$ & & 34 & 34 & 34 & 34 & 34 & 34 \\
\hline Rabbit & $1.97 \mathrm{~kg}$ & & 33 & 33 & 33 & 33 & 33 & 38 \\
\hline Dog & $16.50 \mathrm{~kg}$ & & 49 & 49 & 49 & 60 & 80 & 106 \\
\hline Goot & $22.20 \mathrm{~kg}$ & & 53 & 53 & 53 & 68 & 96 & 138 \\
\hline Mammal & $70.00 \mathrm{~kg}$ & & 52 & 58 & 64 & 98 & 185 & 431 \\
\hline
\end{tabular}

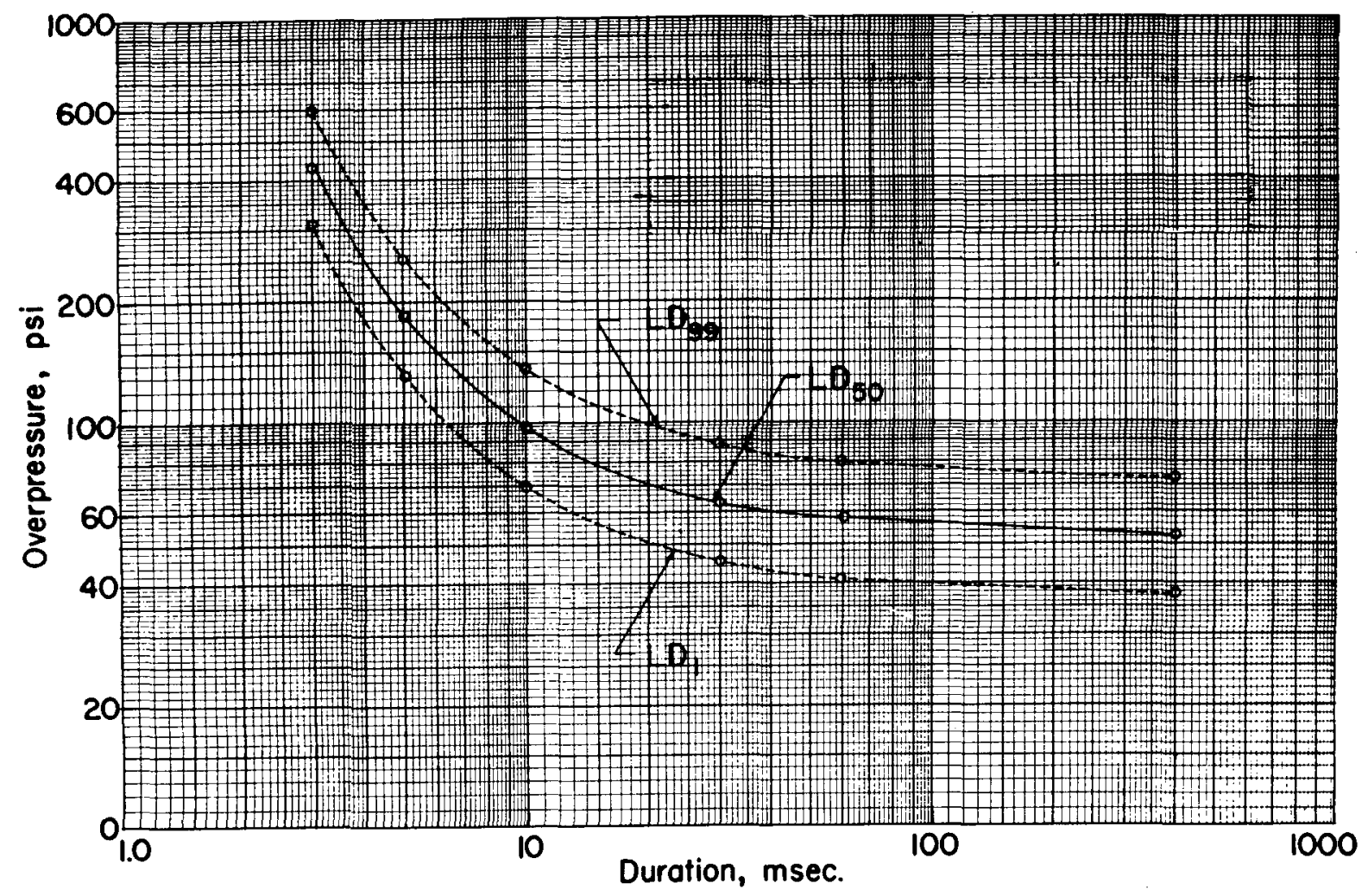

Figure 5-The overpressure-duration relationship calculated for 1,50 , and $99 \%$ lethality for the $70-\mathrm{kg}$ mammal. 
However at this point, it is well to note that the duration of the overpressures for a 100 and 50-psi pulse produced by a 1-kt nuclear burst is near 95 and $150 \mathrm{msec}$, respectively. Consequently, let it be clear that except for detonations much less than $1 \mathrm{kt}$, nuclear-produced overpressures are, for biological purposes, of "long" duration and therefore only the right-hand side of Figure 3 and the $400-\mathrm{msec}$ portion of Table 1 are applicable in assessing mammalian tolerance to nuclear blast. Too, as has been noted previously and as will be discussed below, such data cannot be employed in estimating the biological response to non-ideal wave forms.

\section{c. Estimates for Man}

The best current estimates of the $\mathrm{P}_{50}$ for man were recently set forth by Richmond et al.; 37 they are shown in Table 2 as a function of the duration of "fast"'-rising overpressures. The ranges of overpressures given - for example from 42 to 57 psi for the $400 \mathrm{msec}$ duration pulse - were arbitrarily assigned and they will remain "guestimates" until either reliable human data become available that allow one to establish whether man's tolerance is above or below the mammalian averages now available, or until more data on large animals are obtained.

Similarly, arbitrary ranges of overpressure were recently assigned for "fast"'rising overpressures of "long" duration to give criteria for near one (the threshold) and 100-per cent lethality. These, respectively, were $30-42 \mathrm{psi}$ and $58-80 \mathrm{psi}^{3}$ In the same study, tentative values for the threshold of lung damage and eardrum failure were set forth as shown in the left-hand column of figures in Table 3.7, 8, 10, 20-22, 44 The right-hand column of figures were calculated ${ }^{6}$ and represent the values of the overpressure which, if maximal reflection occurred, would become equal to the numbers in the column labeled "no reflection;" e.g., 6.4 psi will reflect to 15 psi and 2.3 psi will reflect to 5 psi if conditions are appropriate.

TABLE 2 - TENTATIVE ESTIMATE OF PRESSURE - DURATION RELATIONSHIP FOR 50\% LETHALITY IN ADULT HUMANS $(70 \mathrm{KG})^{*}$

\begin{tabular}{|c|c||c|c|}
\hline LD $_{50}$ psi & Pulse duration, msec & LD $_{50}$ psi & Pulse duration msec \\
\hline 42 to 57 & 400 & 78 to 108 & 10 \\
46 to 64 & 60 & 148 to 204 & 5 \\
51 to 70 & 30 & 345 to 474 & 3 \\
\hline \multicolumn{2}{|c|}{ "Applies to "sharp"-rising overpressures of ideal or near-ideal wave forms. } \\
\hline
\end{tabular}

TABLE 3

TENTATIVE CRITERIA FOR PRIMARY BLAST EFFECTS*

\begin{tabular}{|c|c|c|}
\hline \multirow[b]{2}{*}{ CRITICAL ORGAN OR EVENT } & \multicolumn{2}{|c|}{ RELATED MAXIMUM PRESSURE, psi } \\
\hline & $\begin{array}{l}\text { Incident with } \\
\text { no reflection }\end{array}$ & $\begin{array}{c}\text { Incident } \\
\text { with reflection }\end{array}$ \\
\hline $\begin{array}{l}\text { Lung-damage threshold! } \\
\text { Lethality }{ }^{+}\end{array}$ & 15 & 6.4 \\
\hline Threshold & 30 to. 42 & 12 to 15 \\
\hline $50 \%$ & 42 to 57 & 15 to 19 \\
\hline Near $100 \%$ & 581080 & 19 to 25 \\
\hline Eardrum-failure threshold ${ }^{+}$ & 5 & 2.3 \\
\hline \multicolumn{3}{|c|}{$\begin{array}{l}\text { Applies to "fast"-rising overpressures of "long" duration occurring at location of exposure. } \\
+ \text { Data from WT-1179, }{ }^{8} \text { TID-5764, }{ }^{23} \text { WT-1467, }{ }^{10} \text { WT-1470, }{ }^{32} \text { DASA 1242, }{ }^{35} 1245,{ }^{33} 1246,{ }^{34} 1271, \text {, } \\
\text { and Richmond, DASA Project - Unpublished. } 44\end{array}$} \\
\hline
\end{tabular}




\section{d. Free-Field Versus "Geometric" Scaling}

The significance of the potential for pressure reflections and the difference between free-field and "geometric" scaling is well illustrated by some simple shock-tube experiments of Richmond, et al. ${ }^{37,45}$ illustrated in Figure 6. Guinea pigs were exposed inside chambers of three designs; namely, shallow (one-body-diameter deep), deep (three-body-diameter deep) and deep-with-offset (three-body-diameter deep and one-body-diameter offset at the bottom). The $\mathrm{P}_{50}$ 's, in terms of the incident pressures passing down the shock tube and hence over the entrance to the test chambers, were $34.9,19.5$ and 26.8 psi for the shallow, deep and deep-withoffset "foxholes," respectively. However, this repres ented only an apparent al teration of biologic tolerance; for when the pressures were measured inside the deep foxholes close to the thoracic cages of the animals, the $P_{50}$ pressures, due to reflection, turned out to be es sentially similar to that applicable to the shallow chamber; viz., 34.6 and 35.9 psi for the deep and deep-with-offset design, respectively, as set forth in Table 4.45

A careful assessment of the wave forms involved, samples of which are shown in Figures 7, 8, and 9, showed that for the guinea pig, there was no apparent increase in the animal's tolerance providing the time to the reflected maximal pressure was no longer than $0.2 \mathrm{msec}$. However, if it is less than this for the mouse and significantly greater than this for the guinea pig and larger animals, tolerance does increase as will be noted more in detail subsequently.

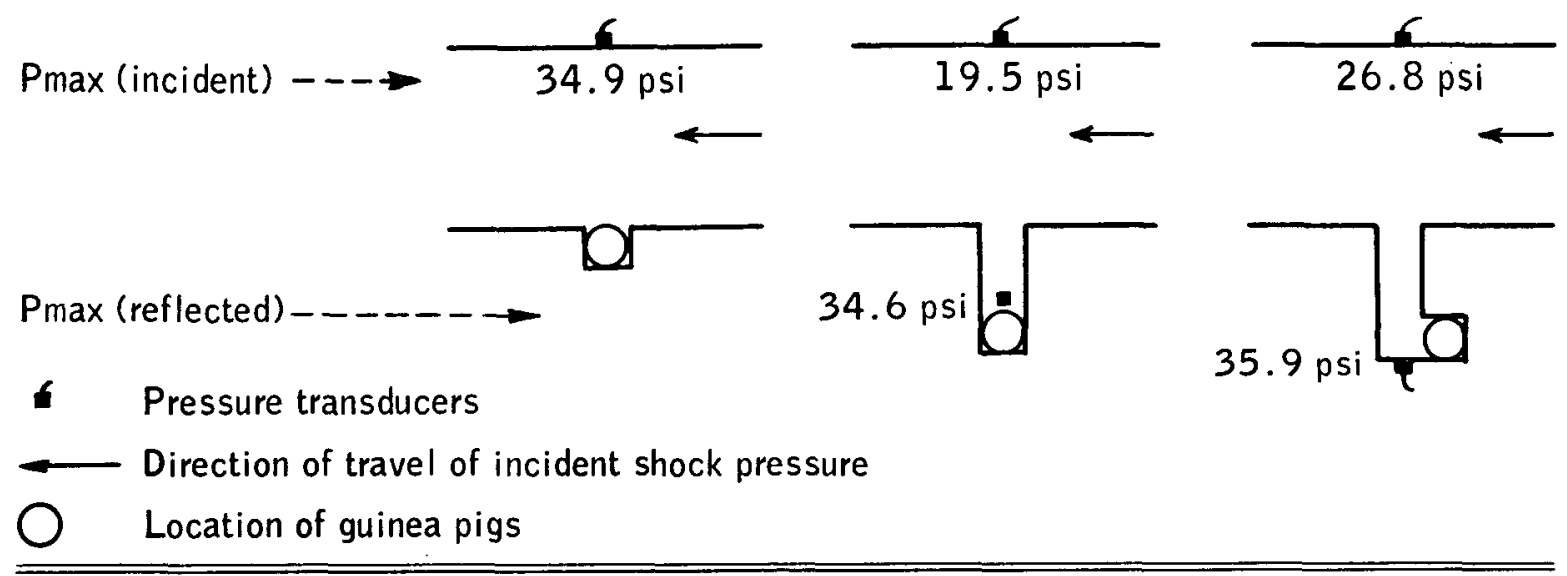

Figure 6 - Maximal incident and reflected overpressures associated with $50 \%$ lethality in guinea pigs as a function of exposure geometry

TABLE 4 RESULTS OF THE PROBIT ANALYSIS RELATING LETHALITY TO OVERPRESSURE*

\begin{tabular}{|c|c|c|}
\hline CHAMBER GEOMETRY & NO. OF GUINEA PIGS & LD 50 psi \\
\hline \multicolumn{3}{|l|}{ Incident shock } \\
\hline Shallow & 40 & $\begin{array}{c}34.9 \\
(33.4 \text { to } 47.8) \dagger\end{array}$ \\
\hline Deep & 38 & $\begin{array}{c}19.5 \\
(17.4 \text { to } 21.0)\end{array}$ \\
\hline Deep-with-offset & 40 & $\begin{array}{c}26.8 \\
(24.2 \text { to } 29.6) \\
\end{array}$ \\
\hline \multicolumn{3}{|l|}{ Reflected pressure } \\
\hline Deep & 38 & $\begin{array}{c}34.6 \\
(31.5 \text { to } 37.2)\end{array}$ \\
\hline Deep-with-offset & 40 & $\begin{array}{c}35.9 \\
(33.0 \text { to } 38.8)\end{array}$ \\
\hline
\end{tabular}




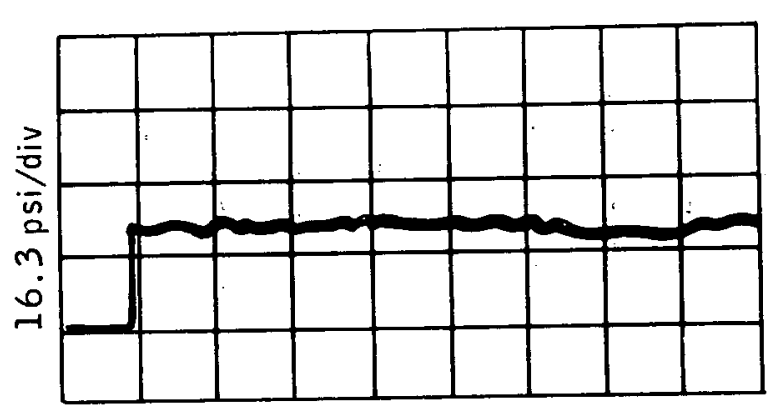

a

$0.5 \mathrm{msec} / \mathrm{div}$

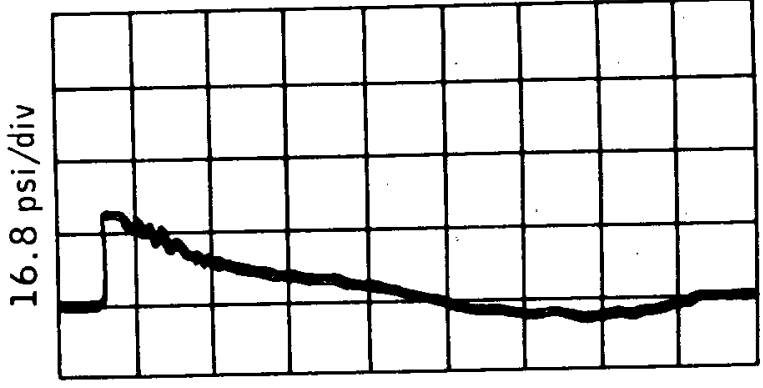

$10.0 \mathrm{msec} / \mathrm{div}$

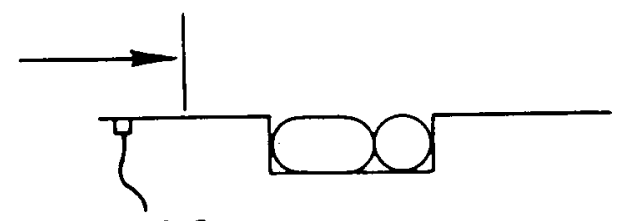

gauge a

Figure 7 - Pressure-time records associated with the shallow chamber.
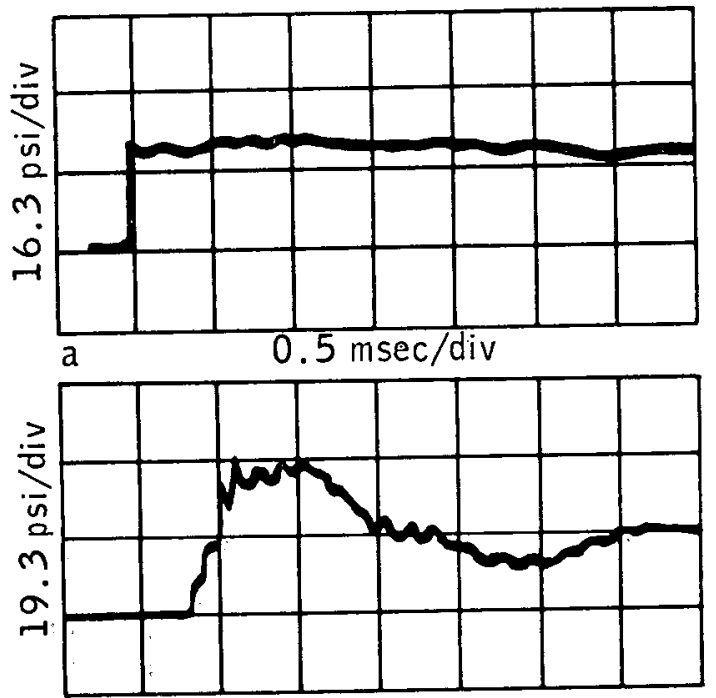

c $\quad 0.5 \mathrm{msec} / \mathrm{div}$

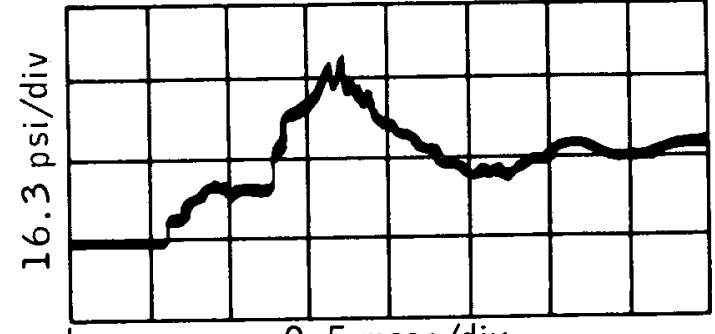

$0.5 \mathrm{msec} / \mathrm{div}$

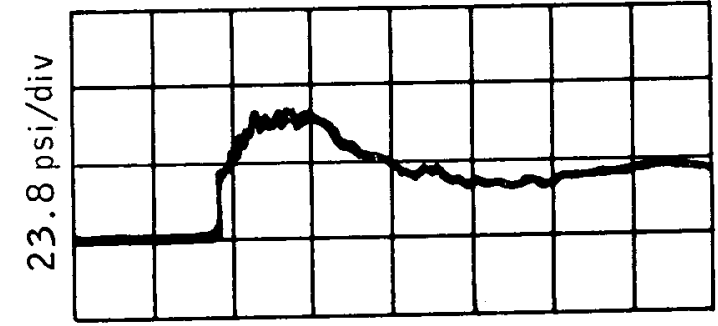

$0.5 \mathrm{msec} / \mathrm{div}$

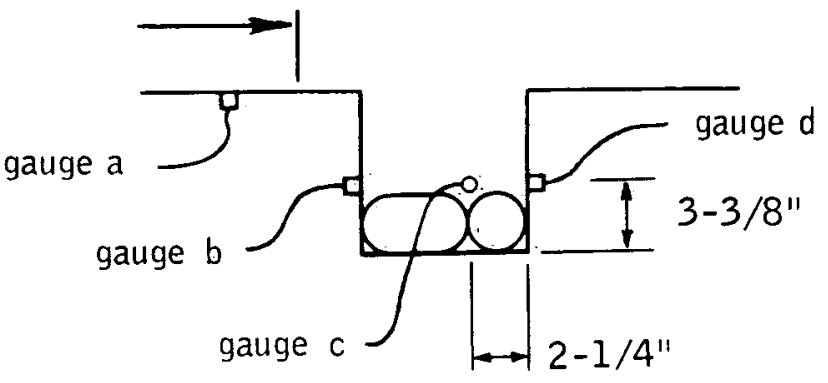

Figure 8 - Pressure-time records associated with the deep chamber. 

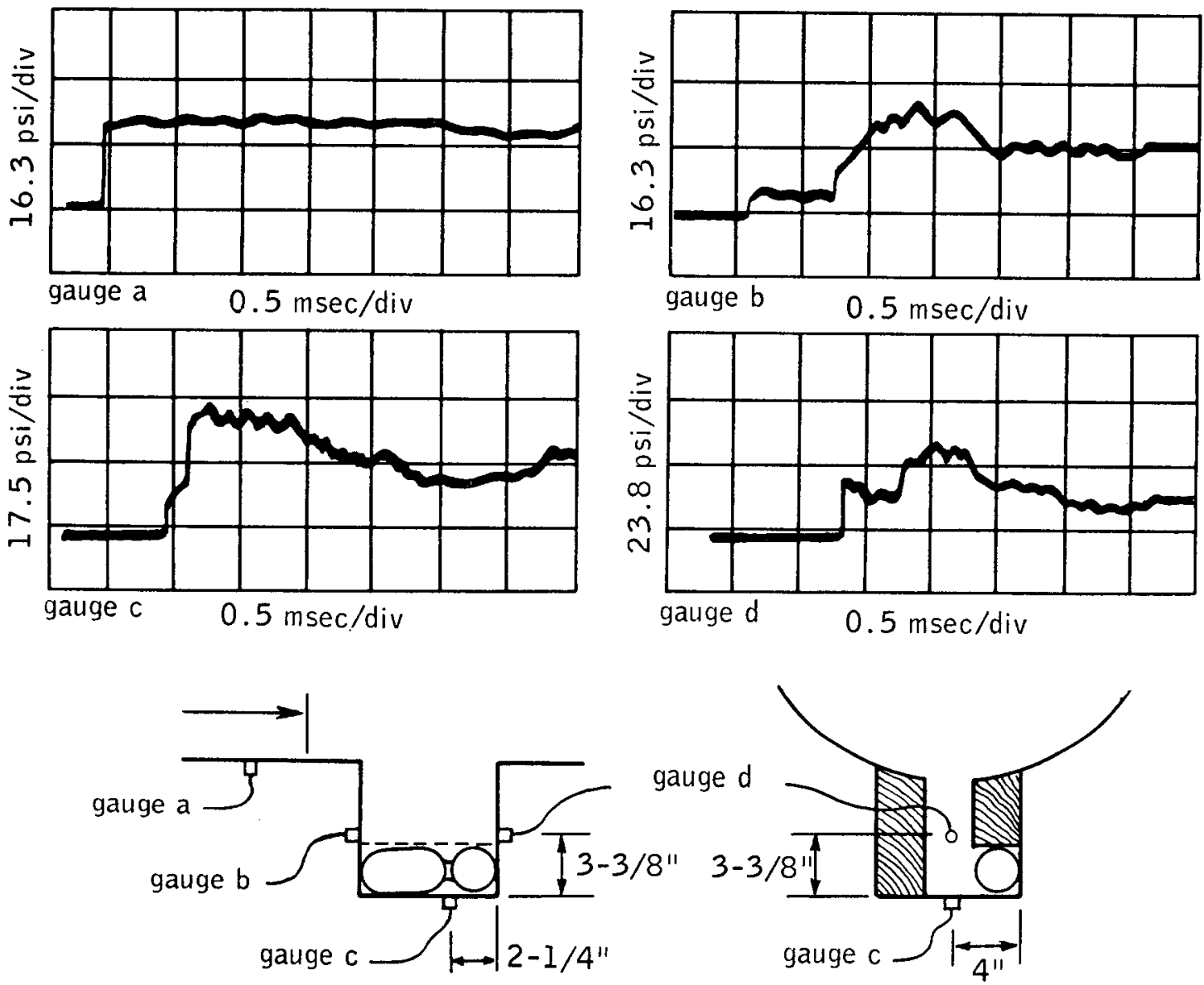

Figure 9 - Pressure-time records associated with the deep-with-offset chamber

\section{e. General}

It is well to note that the tentative estimates for man, given in Table 3

apply to near sea-level conditions, and though the significance of the initial ambient pressure has been appreciated for some time ${ }^{8}$ and a few data on mice indicate that tolerance to "fast"rising overpressures is less at altitude than at sea leve $1,44,46$ more work must be done before firm interspecies data are at hand to refine biological blast scaling as a function of the pressure altitude at which exposure occurs. Similarily, a few exploratory experiments indicate that very young rats are less tolerant than adults of the same species ${ }^{4}$ and future investigations are required to spell out the significance of the age factor. So also is the case for that portion of hazards assessment referable to a performance decrement and even the psi to be associated with the threshold for lung injury yet remains to be placed under systematic study in the several mammalian species.

\section{Disturbed, Atypical or Non-Classical Wave Forms}

Mammalian tolerance to disturbed wave forms is far from as well understood as is the case for classical pressure pulses. However, enough data are available to illustrate that the animal is extraordinarily sensitive to a change in the rising phase of the pressure pulse. Indeed if pressures rise in two "fast" steps with a sufficient delay in time - which is different for each of the species studied to date-between the first and second steps, tolerance (expressed in terms of the reflected maximal pressure) may increase almost 60 per cent. ${ }^{0}, 37,47$ However, if the time to $P_{\max }$ 
is delayed enough and the pressure rise is relatively smooth, tolerance may be elevated as much as four or fivefold that associated with "fast"-rising overpressures of "long" duration. 48.40

Such information is important in assessing the significance of exposure inside a variety of open structures because the geometry involved may serve to alter the wave form significantly; i.e., a free-field pressure pulse of classical form may be altered both in magnitude and in shape. Thus it will be instructive to summarize what is known about biological response to atypical wave forms.

\section{a. "Fast," Stepwise Increases in Overpressure}

If guinea pigs are mounted side-on against the end-plate clos ing a shock tube, they are exposed first to the incident shock and almost simultaneously to the additional reflected shock pressure; e.g., the animal "sees" a pressure pulse of the shape shown at the upper lefthand portion of Figure 10. The $\mathrm{P}_{50}$ under such circumstances is near 37 psi. When the animals are exposed at 1,2,3, 4, 6 and 12 inches in front of the end-plate, they receive the incident pulse followed by the reflected pressure after an interval that increases as the distance from the reflecting plate increases. (See the four lower idealized pressure-time pulses to the left in Figure 10; for actual pressure-time recordings with fast instrumentation, note the curves a and $b$ to the right in Figure 10 ). The $\mathrm{P}_{50}$ values under such circumstances become progressively higher up to between 57 and 59 psi as shown in Table 5.30 Associated with this gain in tolerance of 56 - 57 per cent are increases not only in the magnitude of both the incident and reflected shock pressures, but in the time-interval between their arrival at the animal station as well. The data seem to show that when the delay is 0.1 to $0.2 \mathrm{msec}$ between the arrival of the incident and reflected shock pressures, the animal is adding the pulses. This is so because neither the first nor second pulse of 15.6 plus $32.7 \mathrm{psi}$ for the $0.2 \mathrm{msec}$ interval will, if given alone, produce 50 -per cent lethality. Also, for intervals of 0.3 up to $1.4 \mathrm{msec}$ between pulses, the animal is appreciating the pulses as two experiences, because the second pulses of 36 - 40 psi are producing about 50-per cent lethality, a result to be expected if they were admini stered by themselves.

Be this as it may, it is instructive to note Figure 11 wh ich shows available guinea pig lethality data in two series of experiments. ${ }^{37}$ The results, expressed in a plot of the $\mathrm{P}_{50}$ pressures against the time intervals between the incident and reflected pulses, indicate that tolerance increases when the time interval is greater than $0.2-0.3 \mathrm{msec}$ and levels off at a maximum a little below $60 \mathrm{psi}$ when the time of arrival of the reflected shock is more than 0.5 msec after the applications of the incident shock pressure. The figure also shows a few data for $\operatorname{dogs},{ }^{37}, 48$ which though meager and incomplete, appear to be consistent with the experience with guinea pigs.

It is of interest to contemplate other experiments that not only indicate the surprising ability of the mammal to distinguish very short intervals of time, but show that if the interval between the incident and reflected pressure is appropriate, a maximal reflected overpressure associated with 100-per cent lethality may become nonlethal or very nearly so. Figure 12 shows mortality for mice, rats, guinea pigs and rabbits as a function of distance from a reflecting surface when the shock tube was operated as consistently as possible to give an average incident pulse of about 18 psi followed by a reflected step of 34 psi to yield a maximal reflected pressure of near 52 psi.

The data show a sharp fall in lethality to zero for all species with the exception of the guinea pig. When against or separated from the end-plate by a "short" distance that varies for each species, all the animals add the stepwise increases in overpressure; i.e., lethality is much greater than it would be from either pulse applied separately. At a sufficiently "great" distance from the end-plate, the pulses are not only appreciated separately, but each animal makes some type of adaptation that protects either completely again st the second pulse or sharply reduces the mortality to be expected if it were applied separately. 

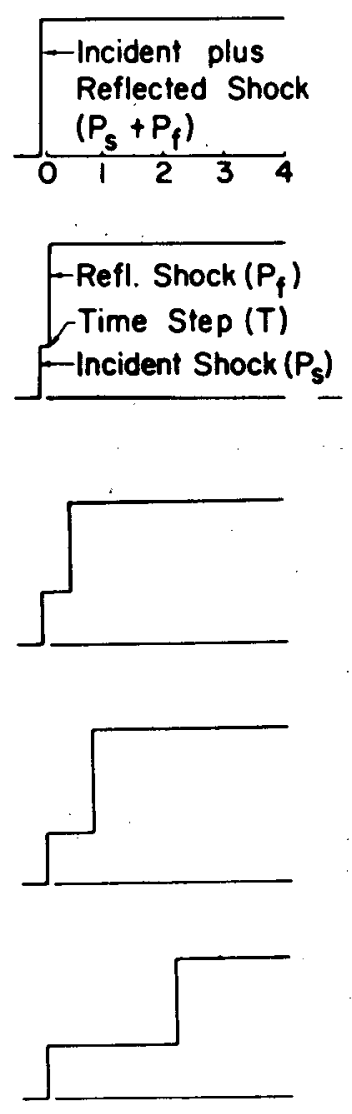

Time, msec

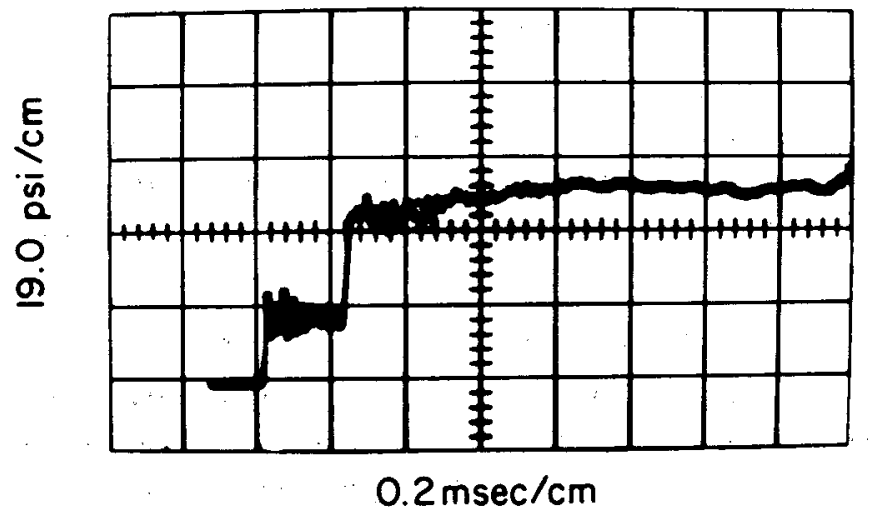

(a) Gauge located 1.5 inches from the Reflecting Plate

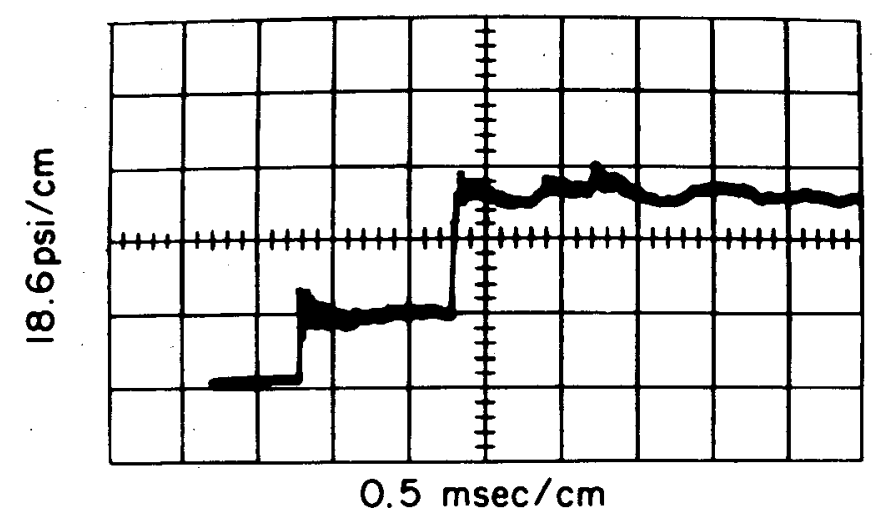

(b) Gauge located 7.5 inches from the Reflecting Plate

Figure 10-Wave forms illustrating almost instantaneous and stepwise increases in overpressure.

TABLE 5

MORTALITY DATA FOR GUINEA PIGS FOR "FAST"-RISING, "LONG" -DURATION SHOCK TUBE-PRODUCED OVERPRESSURES WHEN THE INCIDENT AND REFLECTED OVERPRESSURES ARE APPLIED IN TWO STEPS 25

\begin{tabular}{|c|c|c|c|c|c|}
\hline \multirow{2}{*}{$\begin{array}{l}\text { DISTANCE } \\
\text { FROM } \\
\text { END PLATE, } \\
\text { IN. }\end{array}$} & \multirow[t]{2}{*}{$\begin{array}{l}\text { NO. OF } \\
\text { ANIMALS }\end{array}$} & \multicolumn{3}{|c|}{$\begin{array}{c}\text { OVERPRESSURES ASSOCIATED WITH } 50 \% \\
\text { MORTALITY } \\
\text { IN PSi }\end{array}$} & \multirow{2}{*}{$\begin{array}{l}\text { TIME BETWEEN } \\
\text { APPLICATION OF } \\
\text { INCIDENT AND } \\
\text { RE FLECTED } \\
\text { PRESSURES, msec }\end{array}$} \\
\hline & & $\mathbf{P}_{\mathbf{i}}$ & $P_{r}$ & $P_{r}-P_{i}$ & \\
\hline $\begin{array}{r}0 \\
1 \\
2 \\
3 \\
6 \\
12\end{array}$ & $\begin{array}{r}140 \\
75 \\
78 \\
87 \\
99 \\
109\end{array}$ & $\begin{array}{l}12.1 \\
13.4 \\
15.6 \\
16.9 \\
18.7 \\
18.2\end{array}$ & $\begin{array}{l}36.7 \pm 0.7^{*} \\
40.8 \pm 2.1 \\
48.3 \pm 1.3 \\
52.8 \pm 1.9 \\
58.6 \pm 1.6 \\
57.1 \pm 1.1\end{array}$ & $\begin{array}{l}27.4 \\
32.7 \\
35.9 \\
39.9 \\
38.9 \\
\end{array}$ & \begin{tabular}{l}
\multicolumn{1}{c}{0} \\
$0.10^{\star \star}$ \\
0.20 \\
0.30 \\
0.63 \\
1.36 \\
\end{tabular} \\
\hline \multicolumn{6}{|c|}{$\begin{array}{l}\text { * All plus or minus figures refer to the standard error of the mean. } \\
\text { * Estimated. } \\
P_{i}=\text { incident pressure; } P_{r}=\text { reflected pressure; } P_{r}-P_{i}=\text { magnitude of the second stepwise increase in } \\
\text { pressure. }\end{array}$} \\
\hline
\end{tabular}




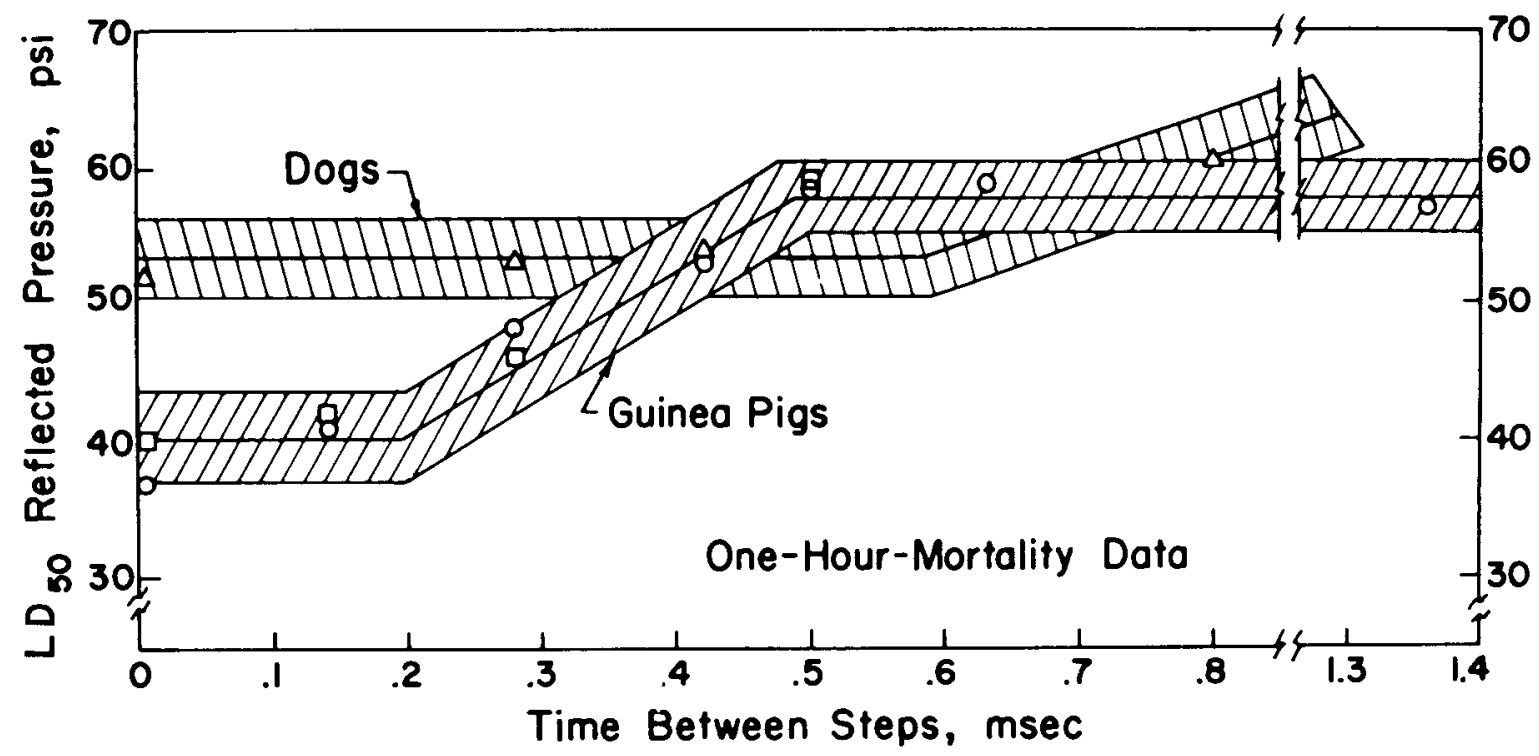

Figure 11 - Tolerance of animals to overpressures applied in two steps.

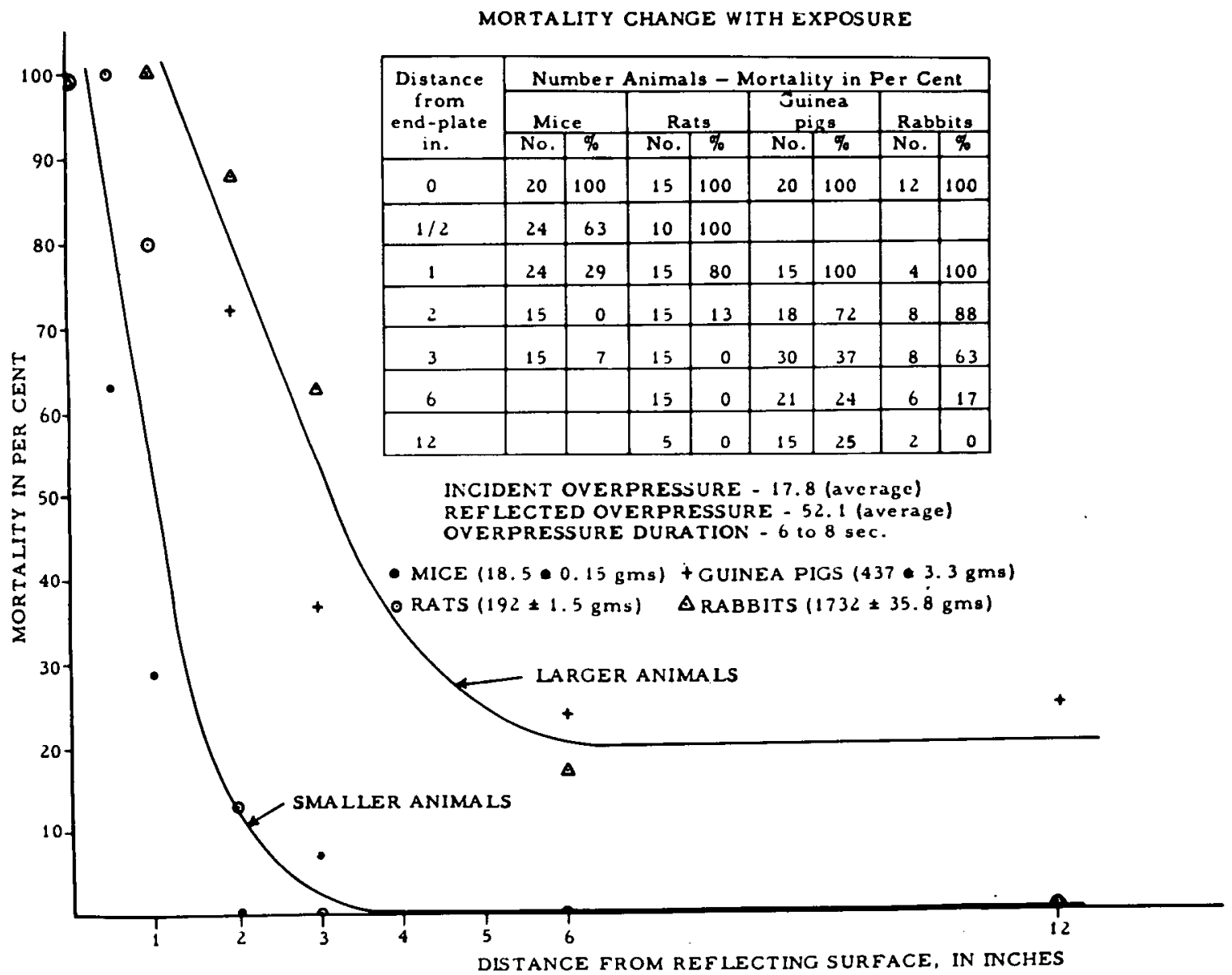

Figure 12 - Mortality variations for anima/s exposed against and at indicated distances from the end plate closing the end of a shock tube. Incident and reflected overpressures varied

from 16.6 to 18.7 and 48 to 55 psi, respectively,

and endured for 6 to 8 sec. 
Though the reasons for the findings are partly understood, they are complex and hardly appropriate to this discussion. Since the data are incomplete and only exploratory in nature and current studies involve subtle frequency and resonance properties of the thoracicabdominal system, it is quite clear that those who would interpret tolerance to overpressure under circumstances where the rising phase of the pressure pulse is disturbed (as it certainly can be inside a variety of structures) must know not only that current data are hardly yet equal to the challenge, but a thorough understanding will require a great deal more quite careful and precise work. This statement deserves great emphasis, for while structures may alter the wave form to allow an increase in tolerance, they may also under certain circumstances allow pressure reflections to occur and hence enhance the damaging potential of a given incident free-field overpressure. Unfortunately, it is not yet possible to establish criteria for atypical wave forms as has been done for classical pressure pulses and the discussion which follows will lend additional support to this view.

\section{b. Other Disturbed Wave Forms}

Beginning in 1957, development of a shock-tube facility for biological use was undertaken in Albuquerque for the Division of Biology and Medicine of the AEC. $44,50 \mathrm{~A}$ few animals were exposed during test procedures arranged to establish performance characteristics of a variety of different geometries conceived to simulate certain desired nuclear blast phenomena. Thus some experience was gained with different wave forms as shock-tube technology was advanced and refined. Though many of the experiments were only exploratory, some interesting facets of mammalian response to overpressure were uncovered. The biological effects of two general types of wave forms will be discussed here; namely, smooth-rising pressures and combinations of single or multiple fast components followed by "crowning," a fairly slow increase to a pressure maximum in excess of the incident and reflected shock pressures.

\section{(1) Smooth-Rising Overpressures}

Richmond et al. ${ }^{48}$ noted that 5 - 20-second duration overpressures rising smoothly to a maximum in about $150,90,60$ and $30 \mathrm{msec}$ were not fatal for dogs even though the maximal overpressures ranged from 74 to $170 \mathrm{psi}$. The wave forms along with the geom etry of exposure and a few notes concerning gross response are shown in Figure $13^{49}$ and Table 6.48 Though smooth-rising overpressures produce sinus hemorrhage, eardrum rupture and pulmonary hemorthage that are not typical of "fast"-rising overpressures, it is apparent they do not offer an immediate threat to the animal. However, more data are needed to establish the relation between lethality and the magnitude of the overpressure when the latter is reached in various periods of time.

\section{(2) "Fast," Stepwise Increase in Overpressure Followed by "Crowning"}

Figure 14, from Richmond et al. 49 showing multiple "fast" components in the rising phase of the pressure pulse followed by a subsequent increase ("crowning") to a maximal pressure, reveals first that when the time to $P_{\max }$ as defined by Figure 15 (which also explains some of the column symbols at the top of Figure 14) is less than $30 \mathrm{msec}$ and the pressure in excess of 140 psi the outcome may be fatal for dogs, though 230 psi may not be lethal even though the time to $P_{\max }$ is near $12 \mathrm{msec}$. Secondly Figure 14 shows that lethality is likely to be common if a single or multiple "fast"-rising shock component characterizes the early portion of the pressure pulse. A corollary to this statement is that minimal overpressures producing lethality are always associated with very "fast"-rising incident or reflected shock pressures.

\section{Orbital Fracture}

Thirdly, the data in Figures 13 and $14^{49}$ document the occurrence of 11 orbital fractures in 9 of 115 dogs as summarized in Table 7. 


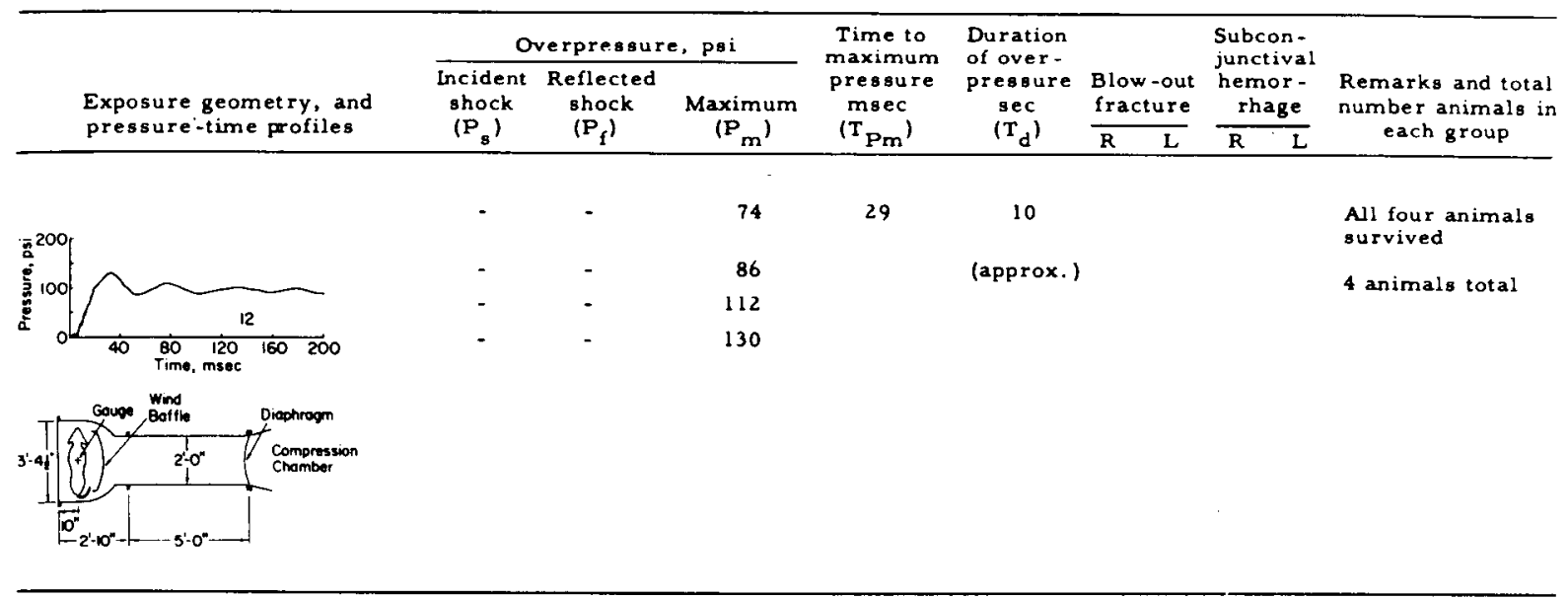

All four animals
survived

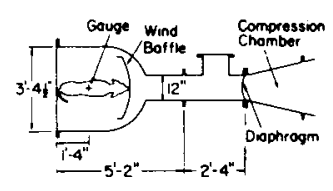

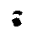

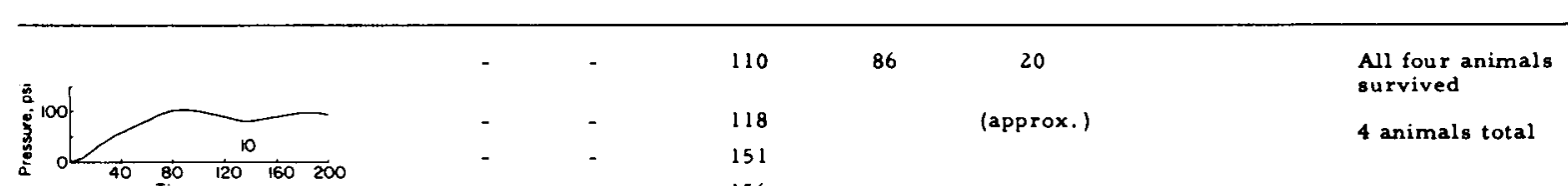

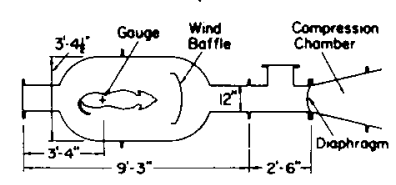

All four animals
(approx.)

-Denotes the absence of "clean" incident or reflected shocks in the pressure pulse.

Figure 13 - Gross biological response following exposure of dogs to "slowly" rising overpressures of "long" duration. 
TABLE 6 - EFFECTS ON DOGS OF LONG DURATION OVERPRESSURE APPLIED AT DIFFERENT RATES

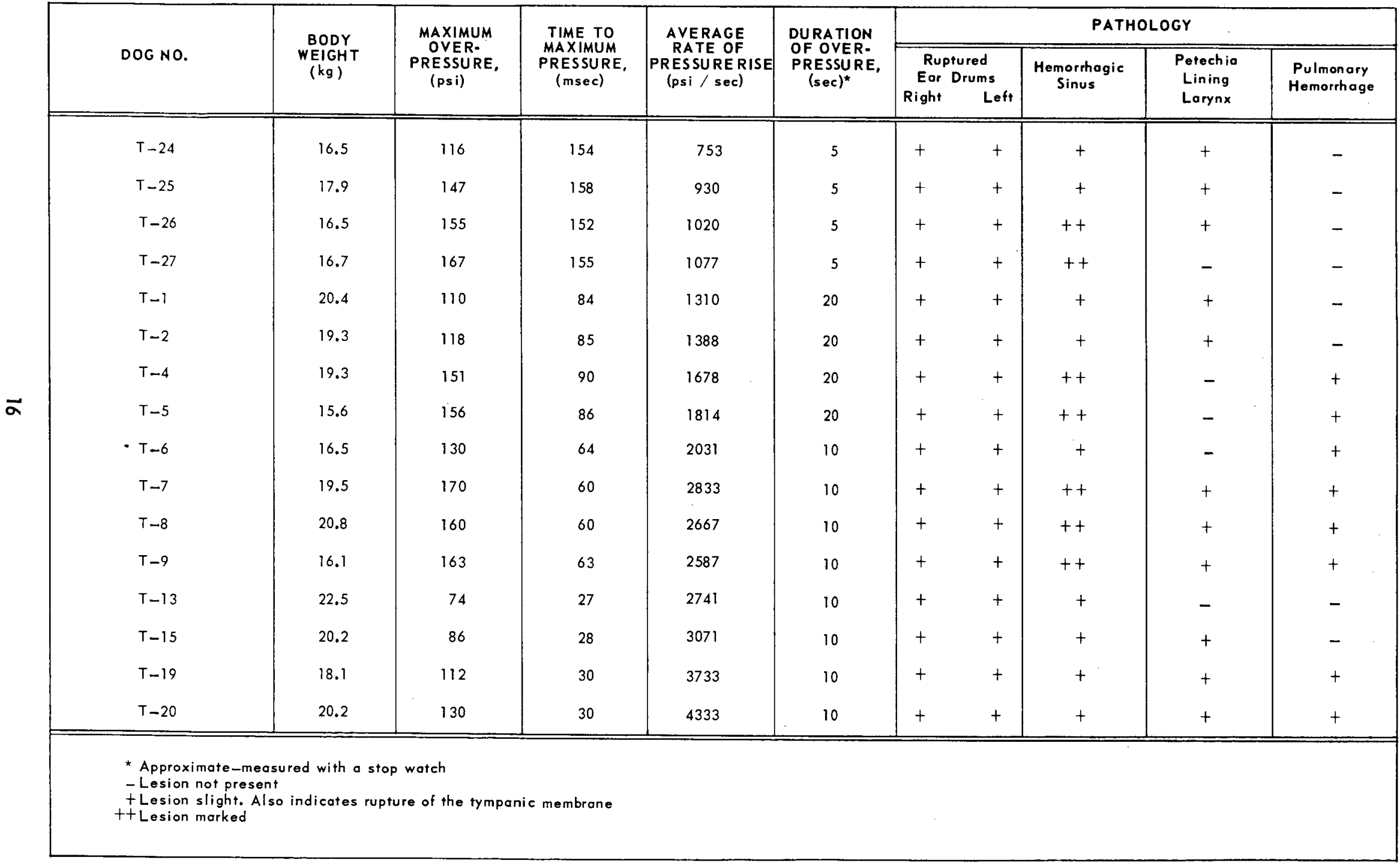




\begin{tabular}{|c|c|c|c|c|c|c|c|c|c|}
\hline \multirow{3}{*}{$\not$} & \multirow{3}{*}{$\begin{array}{l}\text { Exposure geometry, and } \\
\text { pressure-time profiles }\end{array}$} & \multicolumn{3}{|c|}{ Overpressure, psi } & \multirow{3}{*}{$\begin{array}{c}\text { Time to } \\
\text { maximum } \\
\text { pressure } \\
\text { msec } \\
\left(\mathrm{T}_{\mathrm{Pm}}\right)\end{array}$} & \multirow{3}{*}{$\begin{array}{c}\text { Duration } \\
\text { of over- } \\
\text { pressure } \\
\text { sec } \\
\left(T_{d}\right) \\
\end{array}$} & \multirow[b]{2}{*}{$\begin{array}{l}\text { Blow -out } \\
\text { fracture }\end{array}$} & \multirow{2}{*}{$\begin{array}{c}\text { Subcon- } \\
\text { junctival } \\
\text { hemor- } \\
\text { rhage } \\
\end{array}$} & \multirow{3}{*}{$\begin{array}{c}\text { Remarks and total } \\
\text { number animals in } \\
\text { each group }\end{array}$} \\
\hline & & \multirow{2}{*}{$\begin{array}{l}\text { Incident } \\
\text { shock } \\
\left(\mathrm{P}_{\mathrm{s}}\right)\end{array}$} & \multirow{2}{*}{$\begin{array}{c}\text { Reflected } \\
\text { shock } \\
\left(\mathrm{P}_{f}\right)\end{array}$} & \multirow{2}{*}{$\begin{array}{c}\text { Maximum } \\
\left(P_{m}\right)\end{array}$} & & & & & \\
\hline & & & & & & & $\mathrm{R}$ & $\mathbf{R}$ & \\
\hline
\end{tabular}

$\leftarrow$

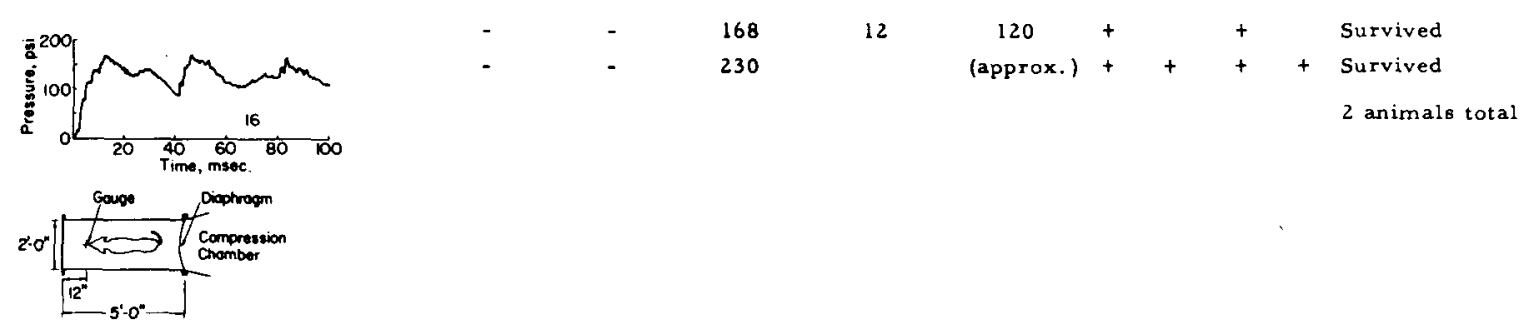

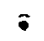

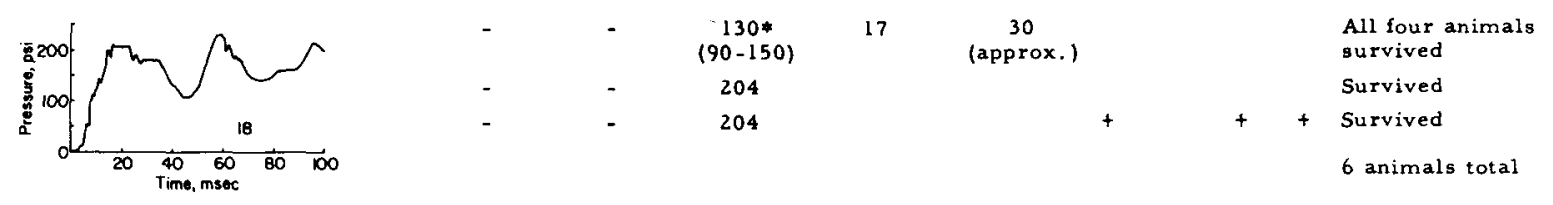
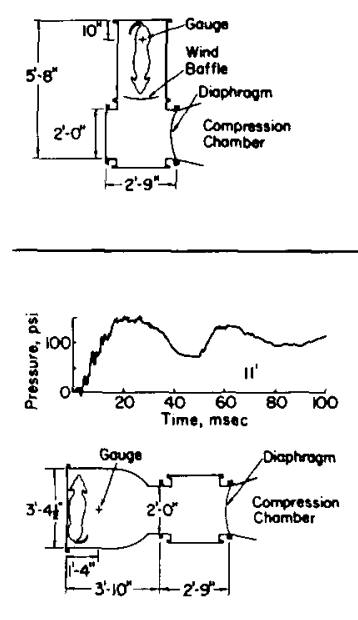

$143 \quad 19+10+\quad$ A blast death

147

(approx.)

Survived

2 animals total

91
92
All 5 animals sur -
vived. Sustained
internal injuries
from impact follow-
ing transiation

* Mean with the range below in parentheses

-Denotes the absence of "clean" incident or reflected shocks in the pressure pulse

tRepresents a positive finding, whereas a blank space denotes a negative finding

Figure 14 - The relation between orbital fractures, exposure geometry and pressure-time parameters 


\begin{tabular}{|c|c|c|c|c|c|c|c|c|c|}
\hline \multirow{3}{*}{$\begin{array}{l}\text { Exposure geometry, and } \\
\text { pressure-time profiles }\end{array}$} & \multicolumn{3}{|c|}{ Overpressure, psi } & \multirow{3}{*}{$\begin{array}{c}\text { Time to } \\
\text { maximum } \\
\text { pressure } \\
\text { msec } \\
\left(T_{\text {Pm }}\right)\end{array}$} & \multirow{3}{*}{$\begin{array}{c}\text { Duration } \\
\text { of over- } \\
\text { pressure } \\
\text { sec } \\
\left(T_{d}\right)\end{array}$} & \multirow{2}{*}{\multicolumn{2}{|c|}{$\begin{array}{c}\text { Blow-out } \\
\text { fracture }\end{array}$}} & \multirow{3}{*}{$\begin{array}{c}\text { Subcon- } \\
\text { junctival } \\
\text { hemor- } \\
\text { rhage } \\
R\end{array}$} & \multirow{3}{*}{$\begin{array}{c}\text { Remarks and total } \\
\text { number animals in } \\
\text { each group }\end{array}$} \\
\hline & \multirow{2}{*}{$\begin{array}{l}\text { Incident } \\
\text { shock } \\
\left(P_{s}\right)\end{array}$} & \multirow{2}{*}{$\begin{array}{l}\text { Reflected } \\
\text { shock } \\
\left(P_{f}\right)\end{array}$} & \multirow{2}{*}{$\begin{array}{c}\text { Maximum } \\
\left(P_{m}\right)\end{array}$} & & & & & & \\
\hline & & & & & & $\overline{\mathbf{R}}$ & $\bar{L}$ & & \\
\hline
\end{tabular}

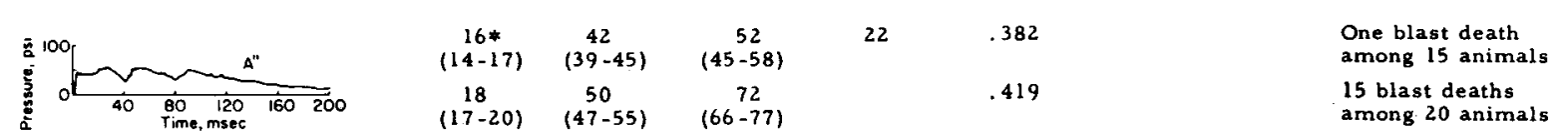

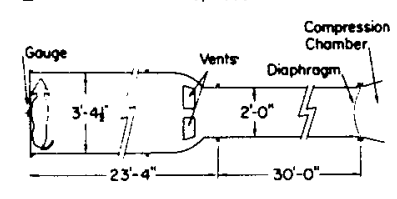

35 animals total

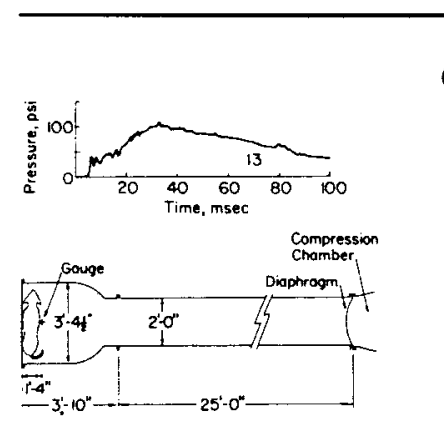

$\begin{array}{ccc}21 * & 46 & 120 \\ (15-28) & (31-63) & (74-157) \\ 23 & 56 & 163 \\ 32 & 74 & 165 \\ 22 & 56 & 166 \\ 32 & 62 & 170 \\ 24 & 62 & 171 \\ 29 & 63 & 171 \\ 28 & 68 & 195\end{array}$

26 5
(approx.)
Two blast deaths among 10 animals

+ Survived

A blast death

Survived

A blast death Survived

A blast death

A blast death

17 animals total

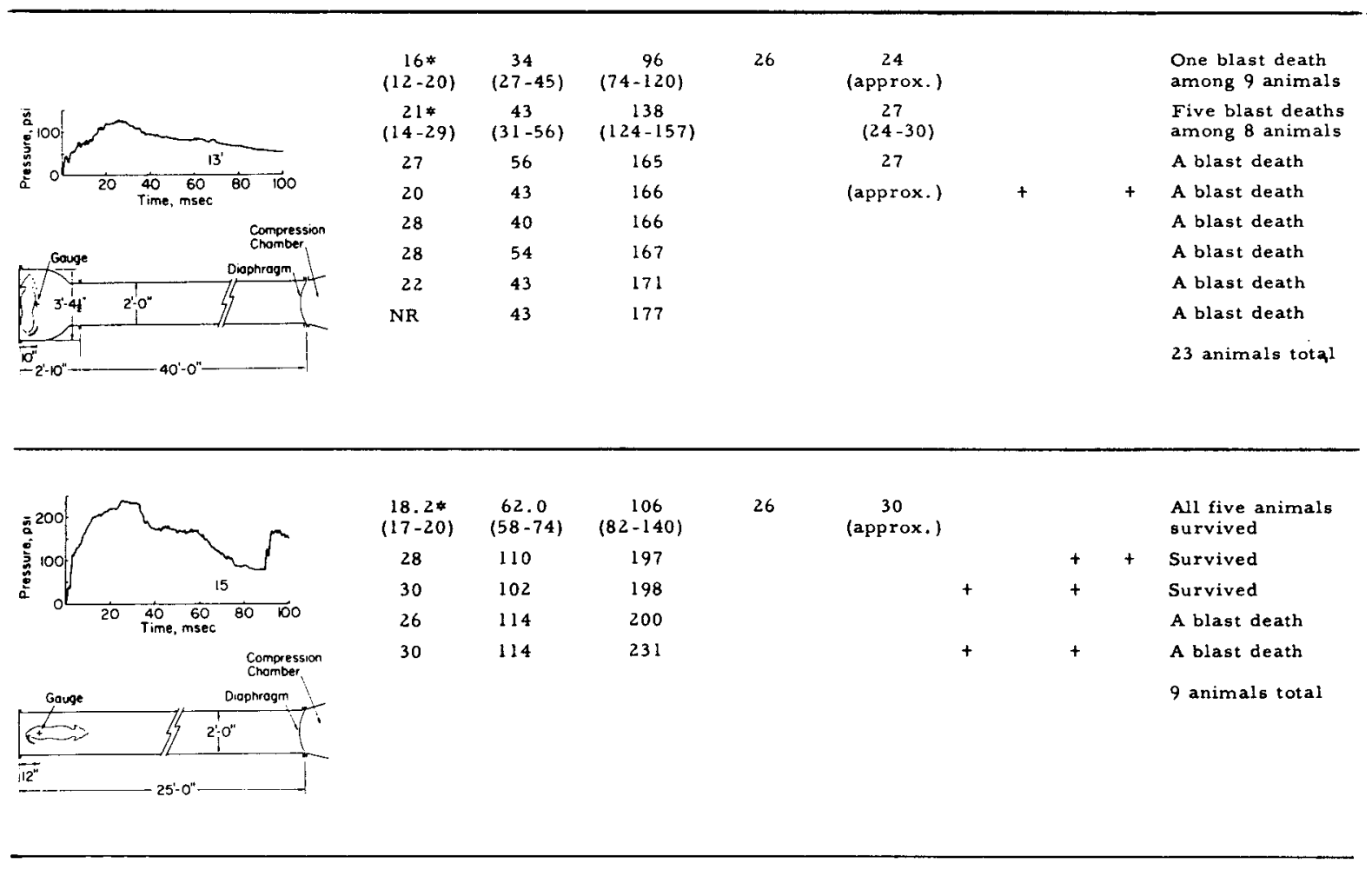

* Mean with the range below in parentheses

NR Indicates there was no record taken of the incident shock

+Represents a positive finding, whereas a blank space denotes a negative finding

Figure 14 (Continued) 


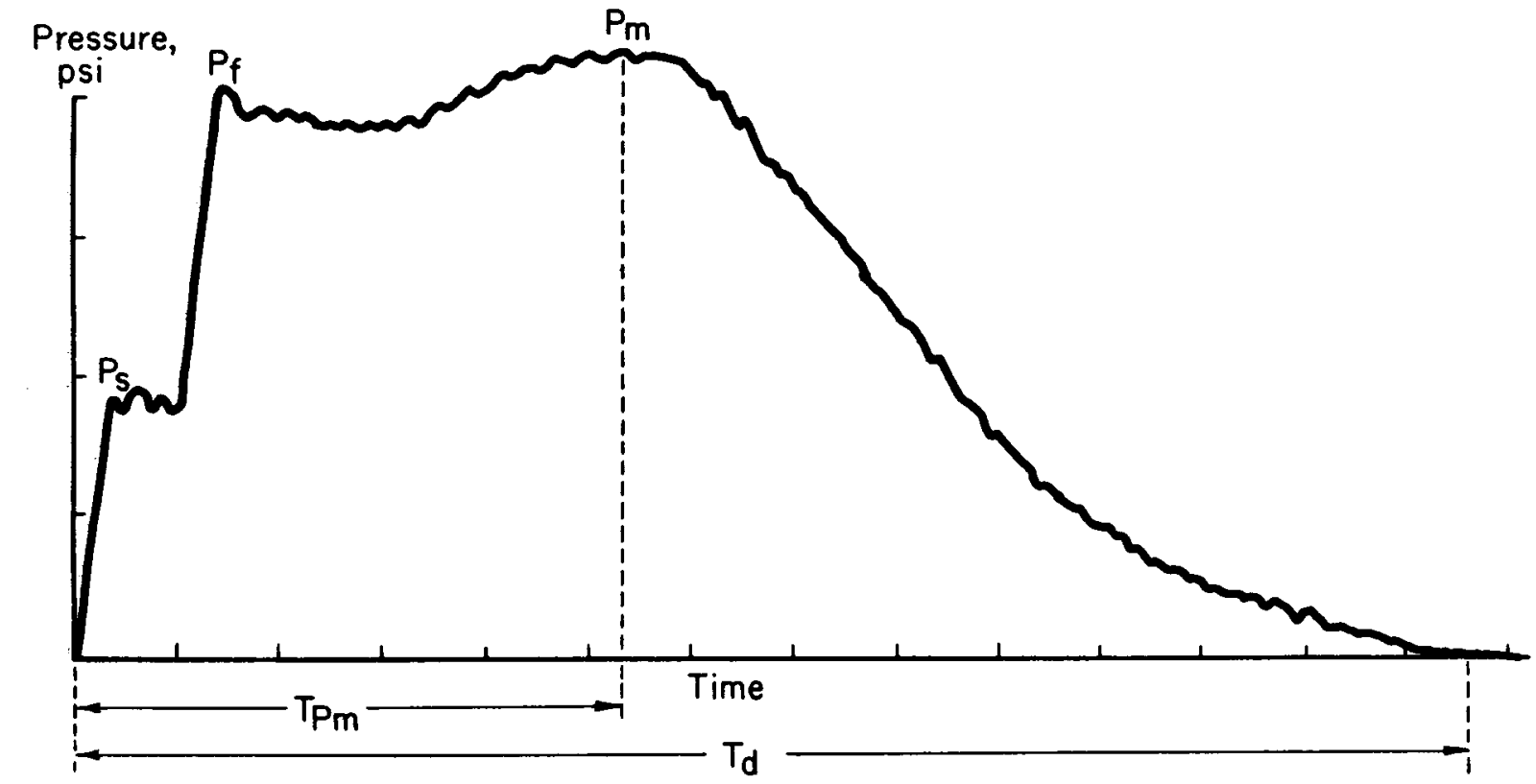

$P_{S}=$ Incident shock pressure, $p s i$

$P_{f}=$ Reflected shock pressure, $p s i$

$P_{m}=$ Maximum pressure, psi

$T P m=$ Time to maximum pressure, milliseconds

$T_{d}=$ Duration of pressure, milliseconds or seconds

Figure 15 - Idealized atypical pressure-time curve

TABLE 7 - THE OCCURRENCE OF ORBITAL FRACTURES IN DOGS AS RELATED TO THE PEAK PRESSURE AND THE TIME TO PEAK PRESSURE

\begin{tabular}{|c|c|c|c|c|c|c|}
\hline \multirow{3}{*}{$\begin{array}{c}\text { OVER- } \\
\text { PRESSURE, } \\
\text { PSi }\end{array}$} & \multicolumn{6}{|c|}{ NUMBER OF FRACTURES AT THE INDICATED TIMES TO PEAK PRESSURE } \\
\hline & \multicolumn{2}{|c|}{10 to $20 \mathrm{msec}$} & \multicolumn{2}{|c|}{21 to $30 \mathrm{msec}$} & \multicolumn{2}{|c|}{31 to $160 \mathrm{msec}$} \\
\hline & $\begin{array}{l}\text { No. of } \\
\text { animals }\end{array}$ & $\begin{array}{c}\text { No. with orbital } \\
\text { fractures }\end{array}$ & $\begin{array}{l}\text { No. of } \\
\text { onimals }\end{array}$ & $\begin{array}{c}\text { No. with orbital } \\
\text { fractures }\end{array}$ & $\begin{array}{c}\text { No. of } \\
\text { animals }\end{array}$ & $\begin{array}{l}\text { No. with orbital } \\
\text { froctures }\end{array}$ \\
\hline 41 to 60 & 0 & 0 & 15 & 0 & 0 & 0 \\
\hline 61 to 80 & 0 & 0 & 25 & 0 & 0 & 0 \\
\hline 81 to 100 & 3 & 0 & 8 & 0 & 0 & 0 \\
\hline 101 to 120 & 0 & 0 & 9 & 0 & 3 & 0 \\
\hline 121 to 140 & 1 & 0 & 6 & 0 & 1 & 0 \\
\hline 141 to 160 & 6 & 1 & 8 & 0 & 5 & 0 \\
\hline 161 to 180 & 2 & 1 & 12 & $2^{\star}$ & 3 & 0 \\
\hline 181 to 200 & 1 & 0 & 3 & 2 & 0 & 0 \\
\hline 201 to 220 & 2 & $\mathrm{I}$ & 0 & 0 & 0 & 0 \\
\hline 221 to 240 & 1 & $1 *$ & 1 & 1 & 0 & 0 \\
\hline TOTALS & 16 & 4 & 87 & 5 & 12 & 0 \\
\hline Percent (animals) & & 25 & & 5.7 & & 0 \\
\hline Percent (orbits) & & 15.6 & & 3.4 & & \\
\hline
\end{tabular}


The orbital fractures, caused by the eyeball and other in traorbital tissues hydraulically transmitting the pressure load to the walls of the orbit more rapidly than counter pressure developed in the air-containing areas bordering the orbit, occurred at maximal overpressures above 140 psi, providing they reached a peak in less than $30 \mathrm{msec}$. Also, the orbital fractures were and were not associated with lethality, depending upon the character of the early portion of the pressure pulse; i.e., if "fast"-rising early components were absent, survival occurred.

\section{Nature of Primary Blast Injuries}

Blast-induced variations in pressure of sufficient magnitude and appropriate wave form characteristically produce damage at or near the junctions of tissues of different density, particularly those included in or immediately adjacent to the air-containing organs of the body. The lung is the most critical organ and primary failure of the fluid-air barrier leads to highly dangerous local events as well as sequelae affecting the early function of other organs vital to life. ${ }^{8}, 19,20-23,34-36,39-42,51,52$ The following selected data are presented to emphasize the extremely hazardous nature of primary blast lesions.

\section{a. Letbality Time}

Among four species of small animals exposed in a shock tube to "fast"-rising overpressures to establish pressure-lethality curves, 287 of a total of 661 expired within two hours. ${ }^{35}$ The lethality-time data are shown in Figure 16. Note that nearly 80 per cent of all animals lethally injured expired within 20 to 25 minutes.

Figure 17 gives the accumulative lethality time for 88 of 132 guinea pigs which were subjected to shock-tube-produced "fast"-rising overpressures. 47 About 90 per cent of the lethally injured animals died within 24 hours, but five expired during the second post-exposure day, and between the second and seventeenth day four others succumbed. These data are interesting for at least two additional reasons and data relevant to both are noted in Figure 18. First, the $\mathrm{P}_{50}$ 's computed for lethality in 1, 2 and 24 hours and for 30 days were 40.3,39.2, 36.2, and 34.3 psi, respectively. Secondly, if the exposed animals are divided into four groups according to the magnitude of the pressure at which exposure occurred as shown by the psi figures at the left of Figure 18, different lethality-time curves are obtained as shown. It is not surprising that more animals died at the higher pressures and did so at earlier times than those exposed to lower pressures, but to have 44 and 48 per cent of the animals in the lowest two pressure groups succumb within one-half hour could hardly have been predicted.

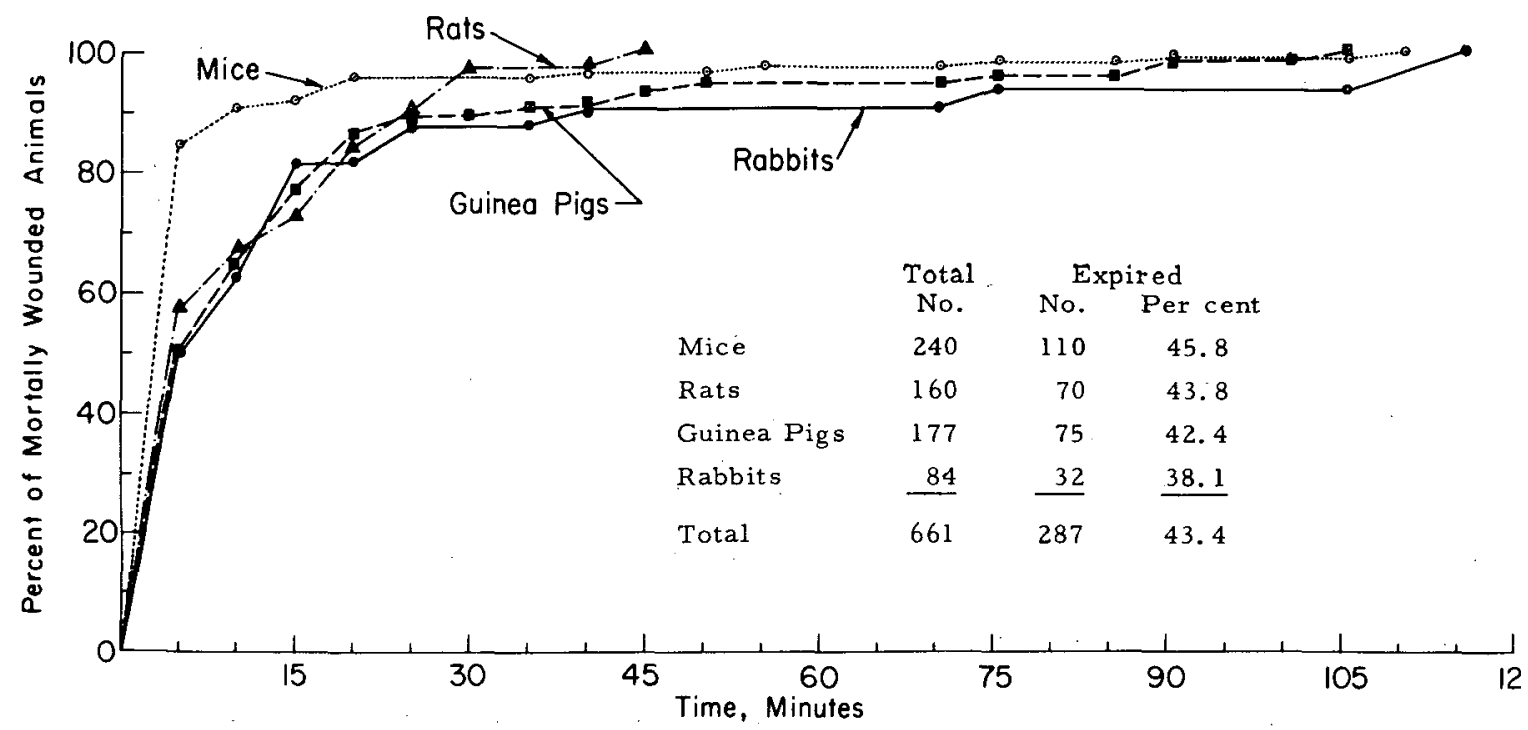

Figure 16 - Cumulative percent of mortally wounded animals dying over a two hour period from exposure to "sharp"-rising overpressures of 3 to $4 \mathrm{msec}$ duration 
Certainly the finding, along with the continuing loss of animals particularly within the first three days, amply illustrates not only the highly hazardous character of primary blast injury, but suggests that only a few if any primary blast casualties will get into medical channels over a one to threeweek post-exposure period; viz., the nuclear explosions in Japan.

\section{b. Critical Lesions}

The massive pulmonary hemorrhage that occurs from primary blast injury can be appreciated by comparing Figures 19, and 20, photographs of the lungs from a nomal animal and one that was fatally injured in a shock tube. Also, air emboli enter the circulation through lesions such as the one shown in Figure 21, a photograph of a ruptured pulmonary vein and the associated hemorrhage into the nearby alveoli of the lung. 1,52 The arterial emboli are disseminated through the peripheral circulation and when they involve the coronary vessels, as Figure 22 illustrates, an early fatal demise from failure of the circulation to the myocardium ensues, 20, 22, 23 Too, brain damage from vascular air emboli also produces signs of malfunction of the nervous system. $24,40,41$

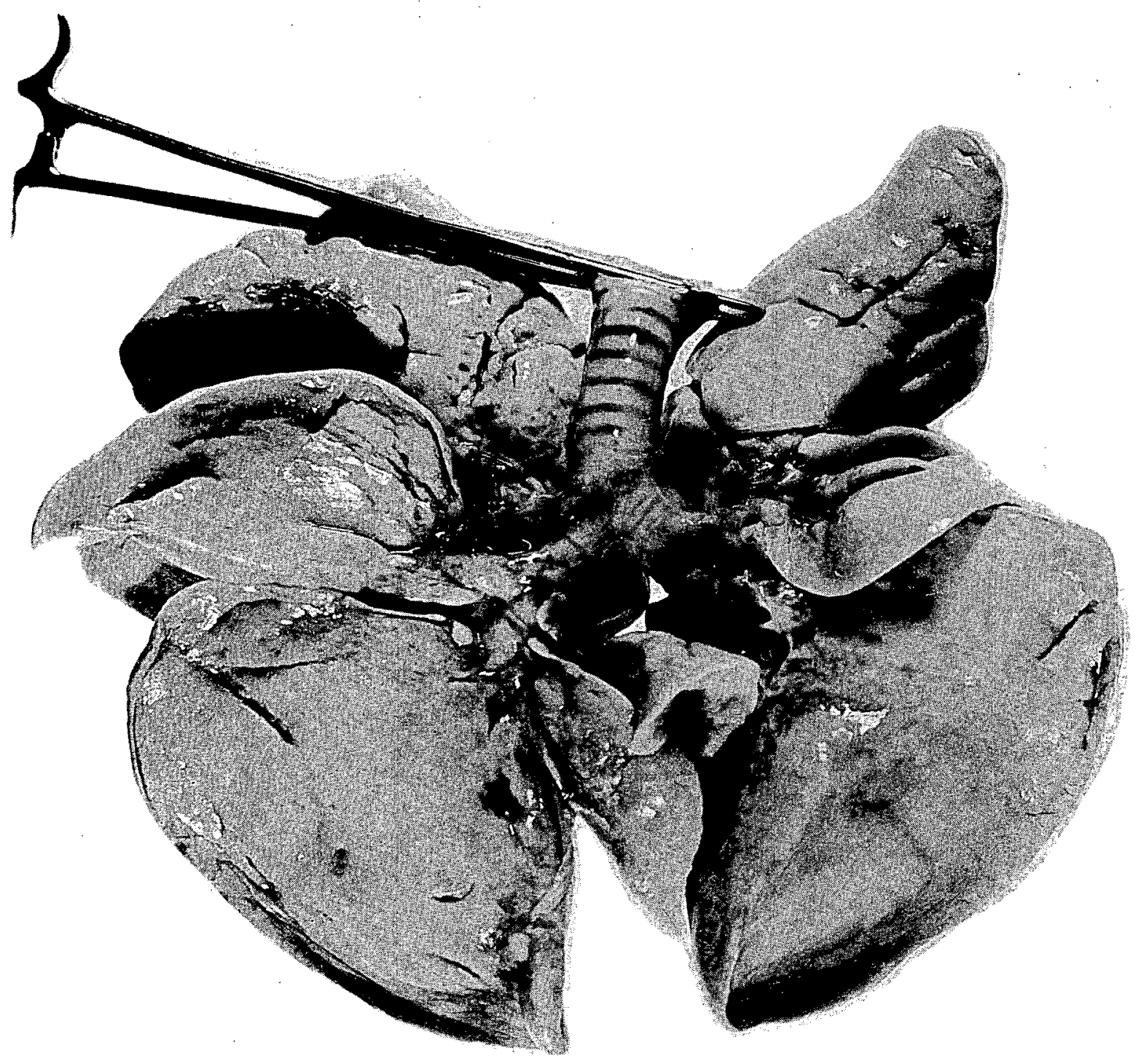

Lovelace

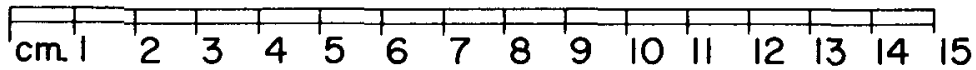

$T-20 \quad 3-8-57$

Figure 19 - L ings of Normal Dog 

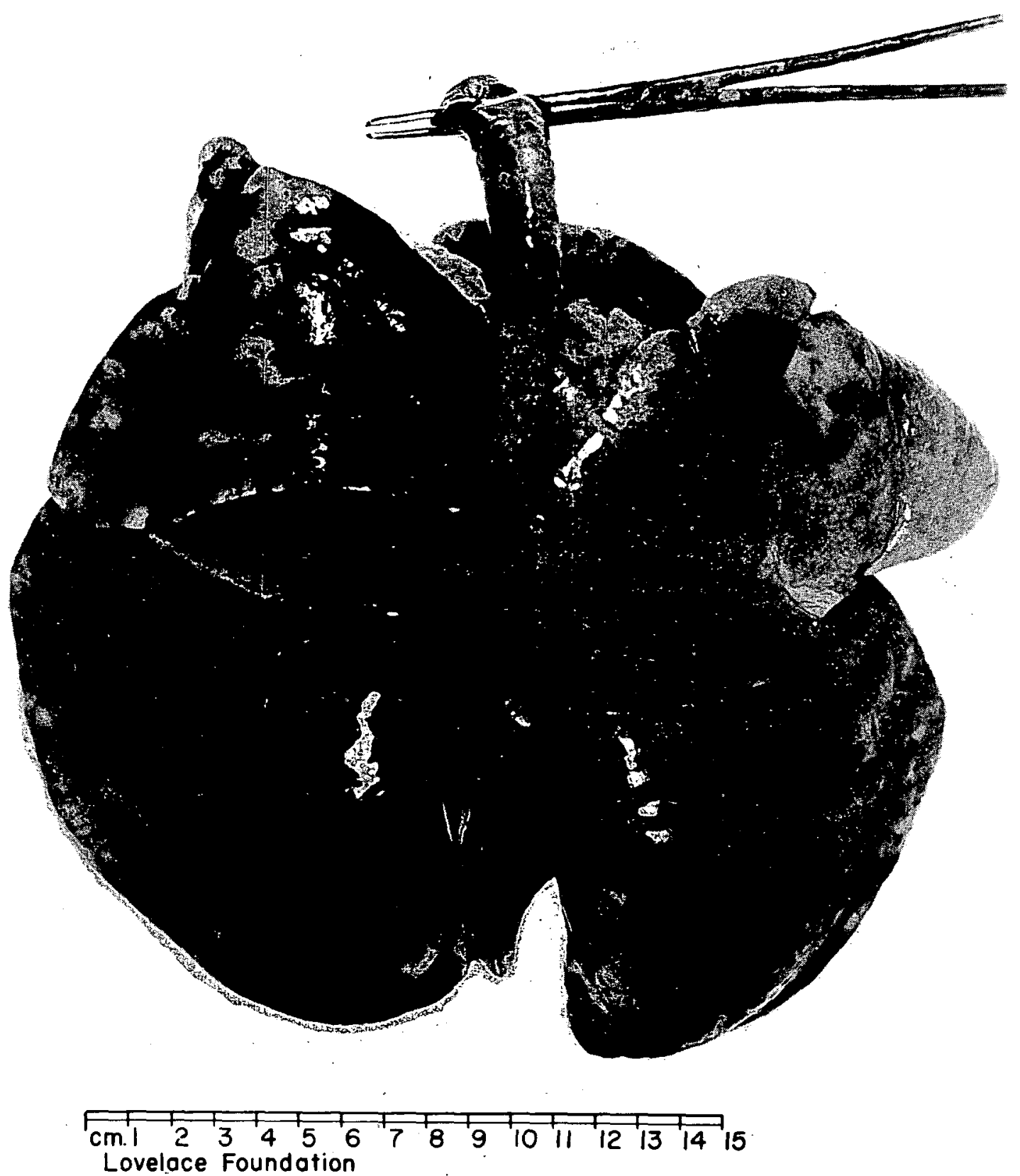

Figure 20 - Lungs of Fatally Injured Dog

Also, continuing damage to the heart from small air emboli and poor pulmonary gas exchange from hemorrhage and edema accounts for subsequent lethality through the hypoxia characterizing suffocation.

Survivors of the acute challenge tolerate exercise poorly, and even if bed rest - a critical need for all blast casualties - can be arranged, there remain the hazards of infective processes and the sequelae of generalized air emboli, abdominal injuries and particularly the postexposure fibrosis and emphysema recently uncovered by Chiffelle ${ }^{32}$ in pathological studies over 90days in dogs surviving exposure to shock tube produced overpressures. 


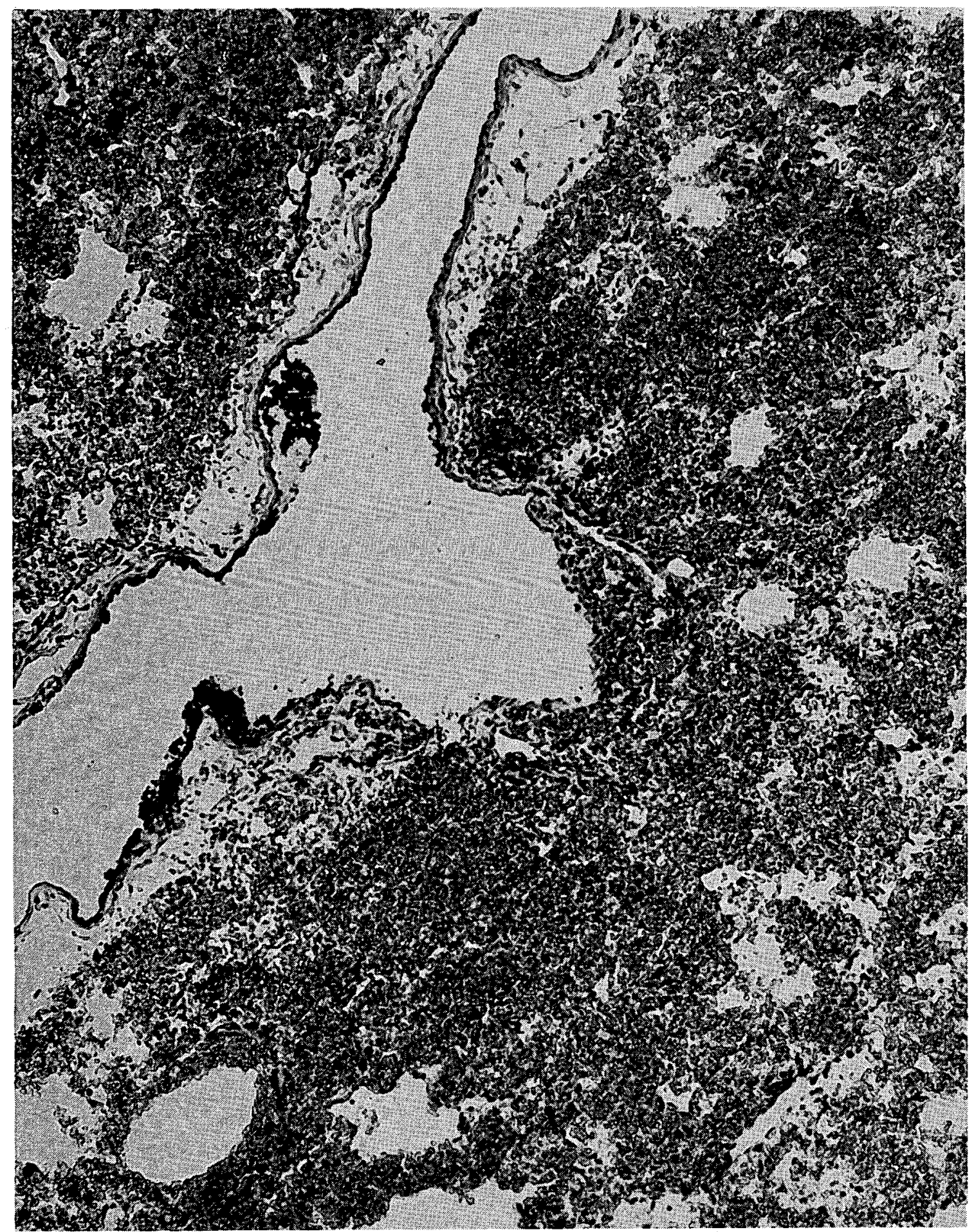

Figure 21

Alveolar venous fistula.

Note failure of wall of pulmonary vein and

hemorrhage into the contiguous alveoli of the lung. 


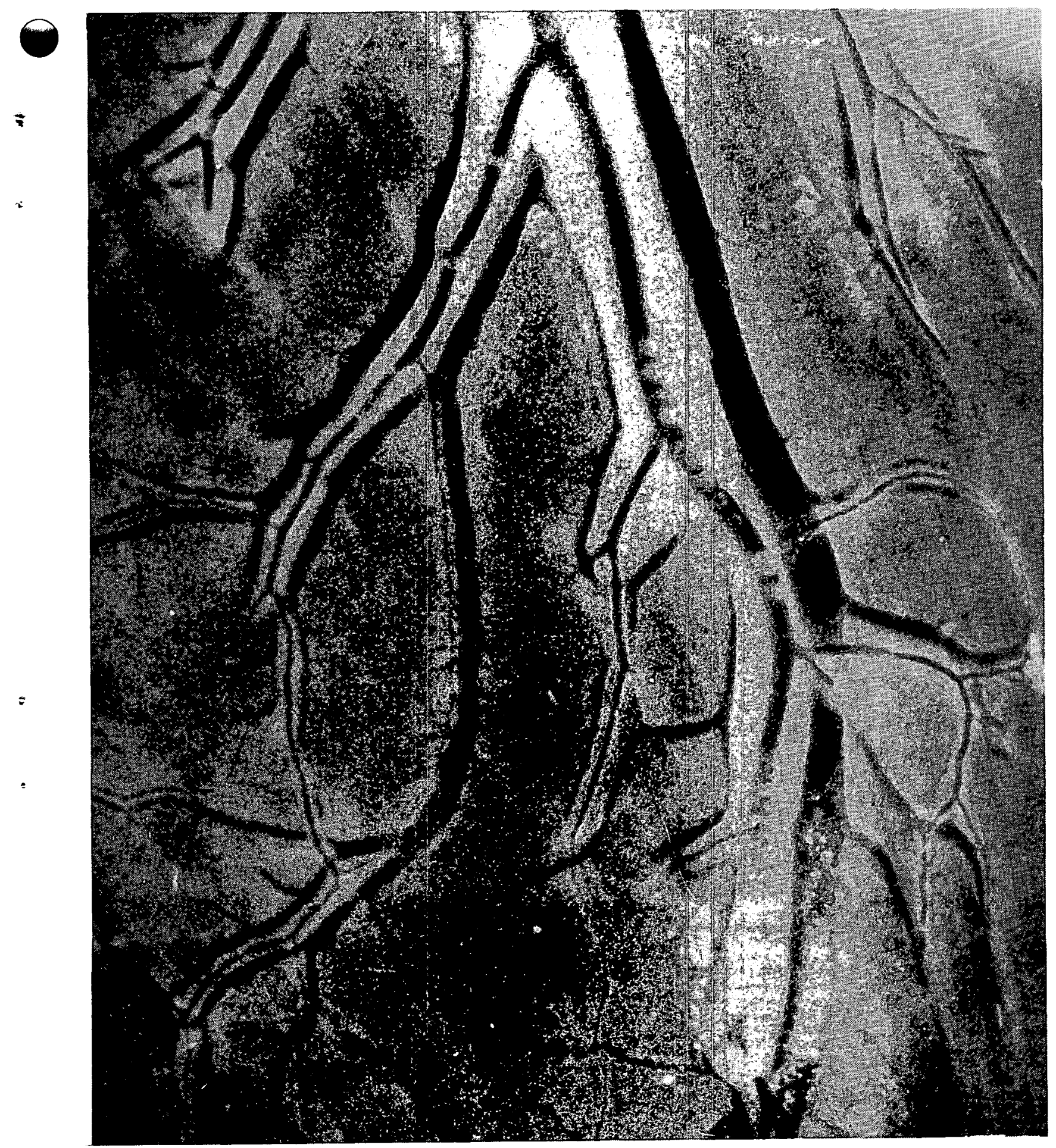

Figure 22

Air embolism of coronary arteries of a dog

fatally injured by blast. 


\section{B. SECONDARY BLAST EFFECTS}

The degree of damage by blast-energized debris is dependent upon many factors. Among them are the weight, shape, density and character of the missiles; their velocity and angle at impact; whether or not penetration of the body wall occurs; and the area or portion of the body involved. Because a great deal of work in wound ballistics and war medicine relevant to these matters has been done and is well summarized in a recent text entitled Wound Ballistics, ${ }^{5}$ this discussion will be limited to missiles of glass and other frangible materials.

Since entry of one of the serous cavities of the body can be regarded as a serious wound at least because infections almost always occur, a study was undertaken several years ago to determine the probabilities of glass missiles penetrating the abdominal wall of dogs when the parameters of missile mass and velocity were the variables. ${ }^{31}$

Figure 23 from Bowen et al. ${ }^{31}$ shows the data. From such information and a field project of Goldizen. et al., ${ }^{32}$ tentative criteria for secondary blast effects applicable to 10-gram (150 grains) glass fragments were set forth as shown in Table 8 , taken from a recent study. ${ }^{3}$ In the same publication, tentative criteria for nonpenetrating missiles were formulated as noted in Table 9 after the work of Lissner and Evans, ${ }^{54}$ Zuckerman and Black, 55 and Gurdjian et al. ${ }^{56}$ The table applies to a blunt object about the weight of an average adult head (10 Ibs) and is based upon the assumption that the skull and its contents are the most critical parts of the body. It may be, however, that trauma to the liver, spleen and abdomen in general is equally hazardous, but relevant quantitative data are not at hand to extend the criteria in this regard.

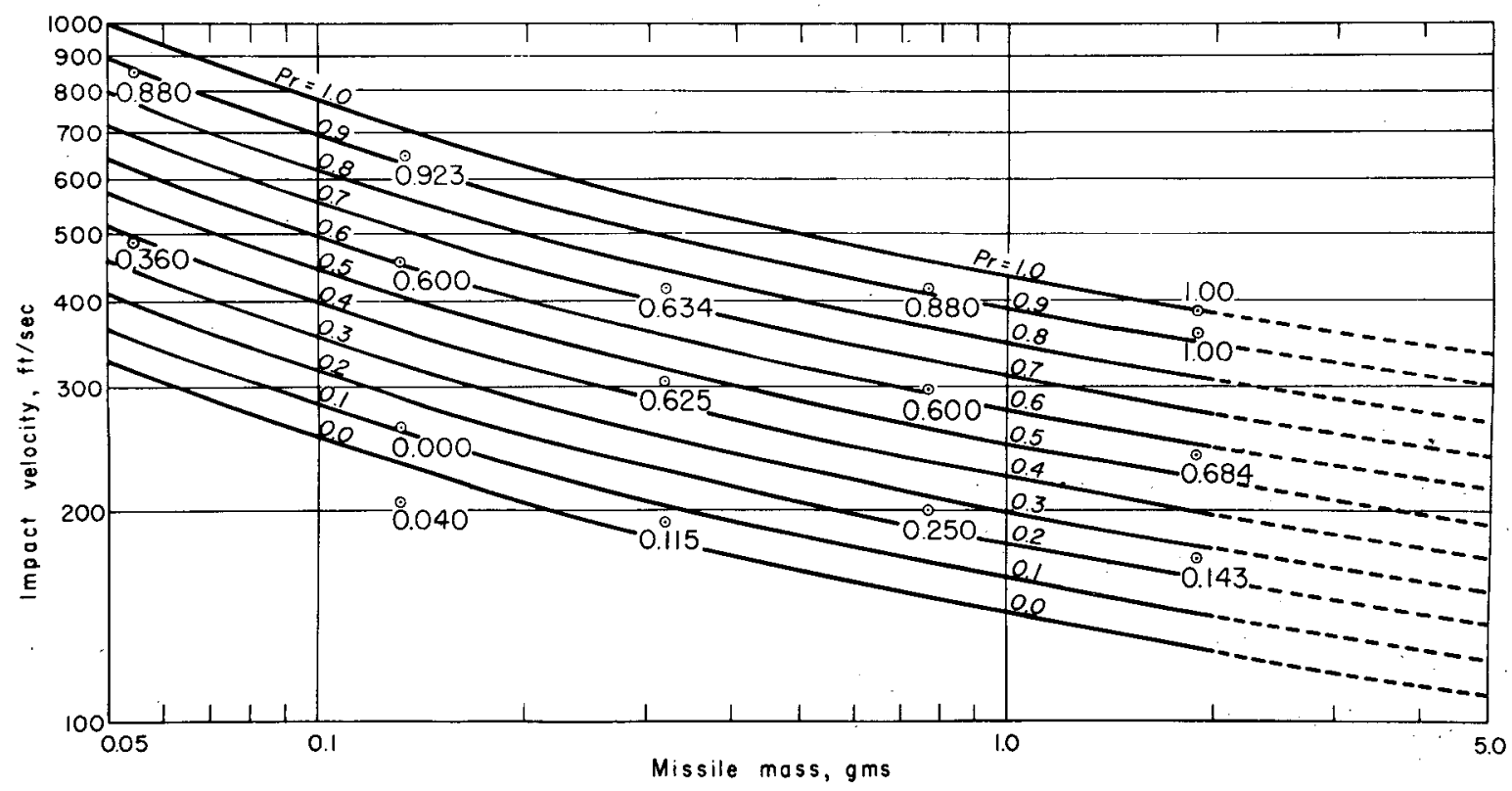

Figure 23

Probability of penetration of glass fragments into the abdomen of a dog as a function of missile mass and impact velocity.

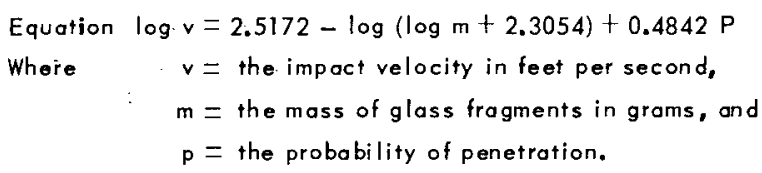


TABLE 8

$\overline{8}$

TENTATIVE CRITERIA FOR SECONDARY BLAST EFFECTS*

\begin{tabular}{|c|c|}
\hline CRITICAL ORGAN OR EVENT & $\begin{array}{c}\text { RELATED VELOCITY FOR } \\
\text { 10-g GLASS FRAGMENT, } \\
\text { ft } / \text { sec }+\end{array}$ \\
\hline Skin-laceration threshold & 50 \\
\hline \multicolumn{2}{|l|}{ Serious wounds * } \\
\hline Threshold & 100 \\
\hline $50 \%$ & 180 \\
\hline Near $100 \%$ & 300 \\
\hline \multicolumn{2}{|l|}{ * Doto from AECU-3350 31 and $W T-1470.32$} \\
\hline + Figures represent impact velocities with & \\
\hline
\end{tabular}

TABLE 9

TENTATIVE CRITERIA FOR SECONDARY BLAST EFFECTS*

\begin{tabular}{|c|c|}
\hline CRITICAL ORGAN OR EVENT & $\begin{array}{l}\text { RELATED IMPACT VELOCITY } \\
\text { FOR } 10-L B \text { OB JECT, } \\
\text { ft/sec }\end{array}$ \\
\hline \multicolumn{2}{|l|}{ Cerebal concussion * } \\
\hline Mostly safe & 10 \\
\hline Threshold & 15 \\
\hline \multicolumn{2}{|l|}{ Skull fracture } \\
\hline Mostly safe & 10 \\
\hline Threshold & 15 \\
\hline Near $100 \%$ & 23 \\
\hline \multicolumn{2}{|c|}{$\begin{array}{l}\text { * Data from Lissner and Evans, } 54 \text { Zuckerman and Black; } 55 \\
\text { Gurdiian, Webster and Lissner. } 56\end{array}$} \\
\hline
\end{tabular}




\section{TERTIARY BLAST EFFECTS}

The implications of the accelerative and decelerative experiences that might be associated with blast-produced displacement of a biological target depends, among other things, upon the magnitude of the forces involved, the time and distances over which they are applied, the velocities attained and the area of the body concerned. Decelerative events, as they are governed by the character and mass of the decelerating object, in all probability repres ent the most important hazard. Since it has been demonstrated that impact with a hard flat surface, an exigency in which only the body tissues are active to "fix" the stopping time and distance, produces a sharp challenge to four mammalian species studied, ${ }^{3}{ }^{3}$ the relevant data will be summarized below.

\section{The Interspecies Impact Study}

To gain biological data applicable to tertiary blast effects, experiments were undertaken several years ago by Richmond et al. ${ }^{3}{ }^{3}$ to determine the velocity of impact which was associated with various levels of lethality. A total of 455 animals were involved. The numbers of lethally injured animals and the total of each species used are tabulated in the central portion of Figure 24 which sets forth the lethality-time data obtained for a 24-hour post-impact period.

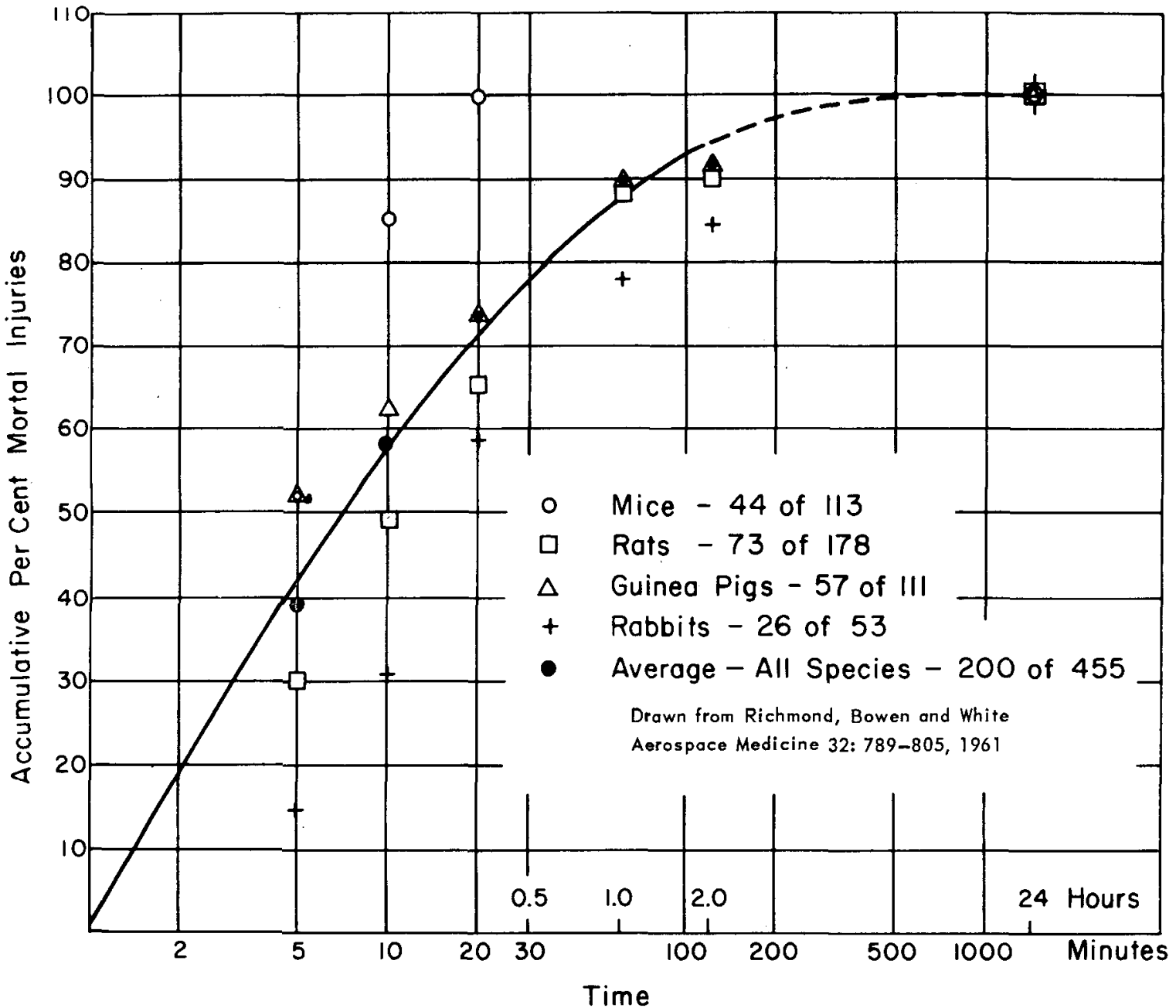

Figure 24 - Average lethality vs. time observed during $V_{50}$ studies. 


\section{a. Early Letbality}

The findings clearly show that early death characterizes the impact syndrome. These was over 60-per cent lethality in one-half hour, and within two hours, over 80 per cent of mortally wounded animals had expired. Thus, impact injury, along with that due to overpressure, has the potential of being a grave blast hazard; any therapy to be effective in each instance must not only be appropriate in kind, but in time. Consequently, in relevant situations a great deal of effort is justified to see that both types of trauma are avoided if at all possible.

\section{b. The $V_{50}$ Data}

It is of interest to note those portions of the study which established the relationship between impact velocity and 50-per cent lethality for each species - the $V_{50}-$ and to note the extrapolation of the results to larger mammals. Figure 25 graphically portrays the $V_{50}$ for each species as a function of average body weight. ${ }^{33}$ Extension of the regression curve allows a $\mathrm{V}_{50}$ prediction of $26.2 \mathrm{ft} / \mathrm{sec}(18 \mathrm{mph})$ for the $70-\mathrm{kg}$ mammal.

Such information along with a review of applicable data from the literature ${ }^{33}$ led to the estimation of tentative impact criteria for $\operatorname{man}^{3}$ as noted in the top portion of Table 10 .

\section{Otber Data}

The lower portion of Table 10 was based upon the findings of Gurdjian, et al. ${ }^{58}$ who, in thẹir study of impact and skull fracture, noted that an impact velocity much greater than that required for skull fracture would produce gross failure of the cranium. The latter finding, along with the high incidence of head injury among automotive fatalities, emphasizes the importance of Table 11 assembled from the work of Gurdjian, et al. ${ }^{56}$ These data, combined with the experiments involving human volunteers by Swearingen, et al. ${ }^{57}$ which established that $10 \mathrm{ft} / \mathrm{sec}$ was near the impact velocity tolerated in the sitting and standing positions, give substance to the lower portion of Table 10.

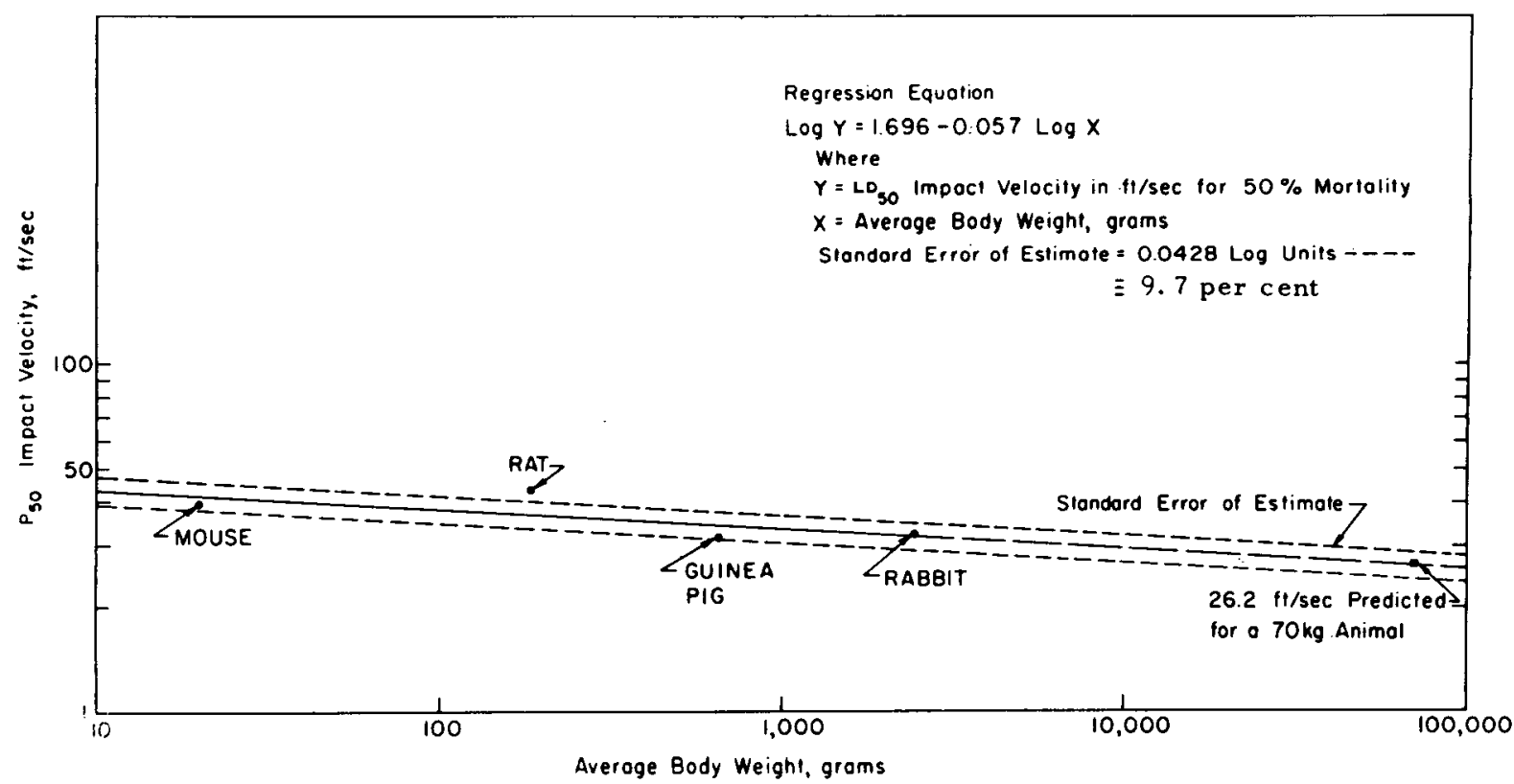

Figure 25

Impact velocity associated with $50 \%$ mortality as a function of average body weight. 
TABLE 10

TENTATIVE CRITERIA FOR TERTIARY BLAST EFFECTS

\begin{tabular}{|c|c|}
\hline CRITICAL ORGAN OR EVENT & $\begin{array}{c}\text { RELATED IMPACT } \\
\text { VELOCITY, } \\
\mathrm{f}+/ \mathrm{sec}^{*}\end{array}$ \\
\hline \multicolumn{2}{|l|}{ Total body +} \\
\hline Mostly "safe" & 10 \\
\hline Lethality, threshold & 20 \\
\hline Lethality, $50 \%$ & 26 \\
\hline Lethality, near $100 \%$ & 30 \\
\hline \multicolumn{2}{|l|}{ Skull fracture ${ }^{+}$} \\
\hline Mostly "safe" & 10 \\
\hline Threshold & 13 \\
\hline $50 \%$ & 18 \\
\hline Near $100 \%$ & 23 \\
\hline
\end{tabular}

TABLE II - THE RANGES OF IMPACT VELOCITIES ASSOCIATED WITH EXPERIMENTAL FRACTURE OF THE HUMAN SKULL*

\begin{tabular}{|c|c|c|c|c|}
\hline $\begin{array}{l}\text { IMPACT VELOCITY, } \\
f \uparrow / \mathrm{sec}\end{array}$ & $\begin{array}{l}\text { APPROXIMATE } \\
\text { VELOCITY, } \\
\text { mph }\end{array}$ & $\begin{array}{l}\text { APPROXIMATE } \\
\text { HEIGHT OF FALL, } \\
\text { in. }\end{array}$ & $\begin{array}{l}\text { NO. OF } \\
\text { SUBJECTS }\end{array}$ & $\underset{\%}{\text { FRACTURES, }}$ \\
\hline 13.5 to 14.9 & 9.5 & 37 & 9 & 19 \\
\hline 15 to 16.9 & 10.9 & 48 & 10 & 22 \\
\hline 17 to 18.9 & 12.2 & 61 & 12 & 26 \\
\hline 19 to 20.9 & 13.6 & 75 & 11 & 24 \\
\hline 21 to 22.9 & 15.0 & 91 & 4 & 9 \\
\hline \multicolumn{3}{|l|}{ TOTAL } & 46 & 100 \\
\hline \multicolumn{5}{|c|}{$\begin{array}{l}\text { * Assembled from the data of Gurditan et al. } 56 \\
\text { Minimum velocity with fracture, } 13.5 \mathrm{ft} / \mathrm{sec}(9.2 \mathrm{mph})\end{array}$} \\
\hline \multicolumn{5}{|c|}{ Maximum velocity with fracture, $22.8 \mathrm{ft} / \mathrm{sec}(15.5 \mathrm{mph})$} \\
\hline \multicolumn{5}{|c|}{ Maximum velocity without fracture, unstated. } \\
\hline
\end{tabular}




\section{THE FREE-FIELD R ANGE-YIELD-EFFECTS RELATIONSHIP}

Establishing a range-yield-effects relationship to further the understanding of biological effects of nuclear explosions requires first that biological criteria relevant to hazards assessment be available, and secondly that at least an initial attempt be made to re late these to the major effects parameters characterizing the explosive source. Once these things are done, one should move along to additional tasks; namely, those required to better understand all the problems involved to the end that essential data are obtained and progressive refinement of the analytical approach ensues.

Though incomplete and crude, tentative biological criteria have been set forth ${ }^{3}$ and summarized above for blast effects. Also, an initial attempt has been made to establish a relationship with the major effects parameters using the free-field scaling laws ${ }^{3}$ and the data of Bow en and associates ${ }^{2}, 31,58-00$ to scale translational effects for animate as well as inanimate objects. Figure 26, applicable to surface bursts at sea level and which also includes scaled data for thermal and initial ionizing radiations in the form of curves for first and second degree bums and for 100 and $200 \mathrm{rem}$, is a representative example of what may be called a comparative range-yieldeffects diagram. ${ }^{3}$ In the context of the present discussion, several comments are in order.

First, Figure 25 shows that the range for each of the effects parameters increases with explosive yield.

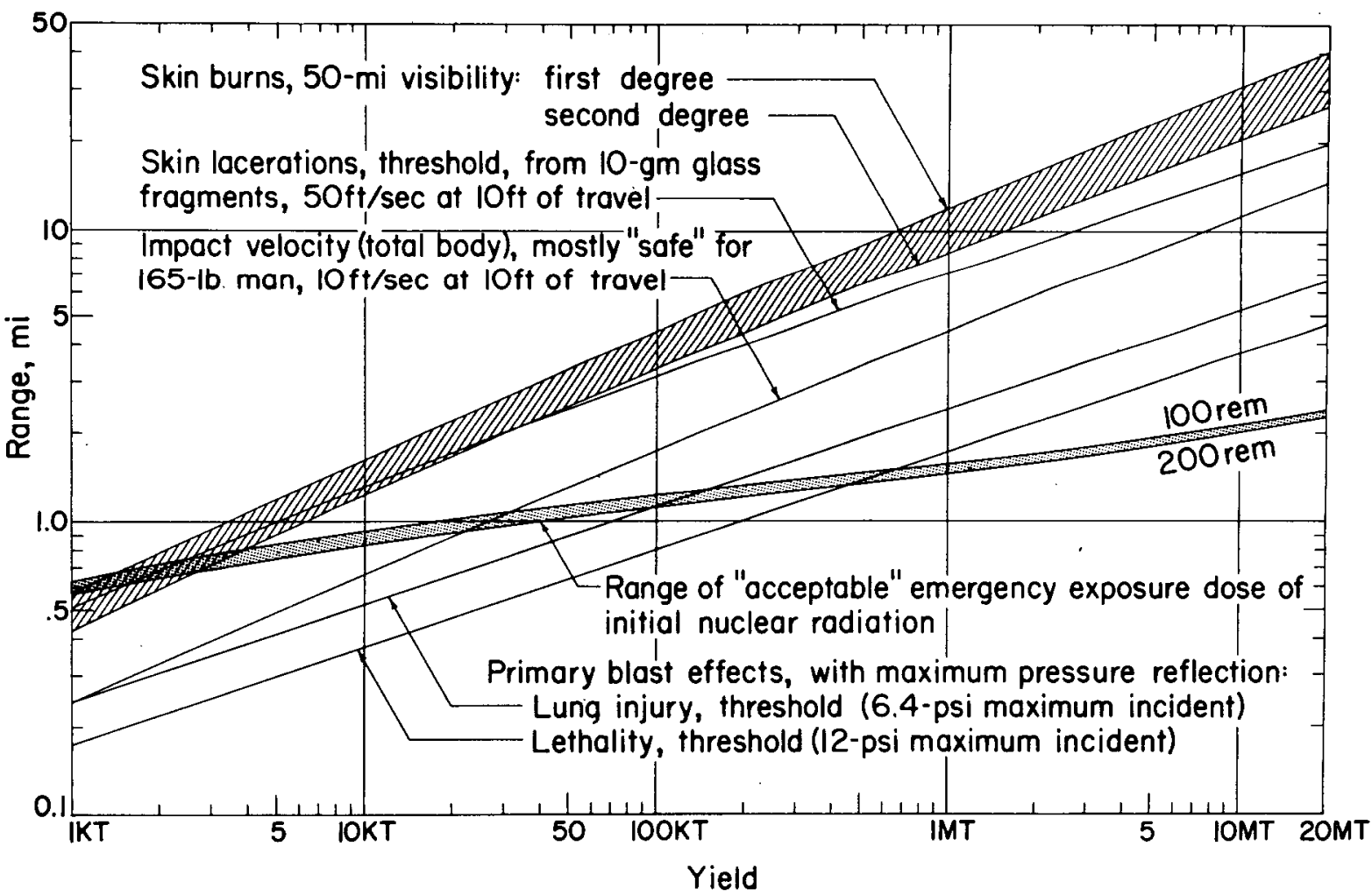

Figure 26 - Comparative effects data showing ranges inside which indicated biological responses may occur for sea-level surface bursts. 
Second, because the range increase with yield is the least for initial nuclear radiation and the greatest for thermal radiation with blast overpressures in between, * the free-field hazards are comparatively different at any range for low, intermediate and high explosive yields This means that for less than a few kilotons the initial nuclear radiation places an area at hazard which is relatively great compared with blast and thermal effects; but for hundreds of kilotons and many megatons, thermal and all blast effects (primary, secondary and tertiary) encompass areas of risk that far exceeds those for initial nuclear radiation.

Third, the slope of the impact-velocity curve is comparable to that of second degree burns and is exceeded only by the rate of rise of the first degree burn curve. Therefore, for high-yield explosions, the potential for impact injury associated with displacement becomes a matter of major concern over very great areas from ground zero.

Fourth, any casualty or other effects data applicable to a given yield must be extrapolated to another yield with great care; this is so at least because the comparative range of the freefield effects parameters vary so greatly with explosive yield.

Fifth, since the hazard spectrum changes at any given range with yield, it is important to know that the effects, both physical and biological noted at Hiroshima and Nagasaki, apply only to that portion of Figure 26 which lies near $20 \mathrm{kt}$ and then only if proper allowances are made for differences due to burst height and to conditions of exposure if one's interest is in biological effects.

Sixth, since blast effects have the potential for producing early lethality, it is important to learn all possible about mortality and survival in the high-pressure areas in both Japanese cities. Even though very high levels of initial ionizing radiation occurred at the close-in ranges in Japan, Figure 26 implies that the radiation dose associated with a given overpressure will progressively decrease the higher the yield. Figure 27 'applicable to surface bursts at sea level and showing how the relationship between overpressure and initial ionizing radiation is influenced by explosive yield, illustrates this point very well. For example, at $10 \mathrm{psi}$, the initial ionizing radiation would be near $3 \times 10^{4}$ rem for a 1-kt yield, but only about 10 rem were the yield as large as IMT.

Seventh, because it seems that any refined assessment of hazard needs be made on the basis of the environmental variations existing at the location of a biological target, it is important to know how much the comparative effects data in Figures 26 and 27 can be altered by the geometry of exposure. As a step in this direction, it will be useful initially to apply the available hazards criteria on a free-field basis specifically to Hiroshima and Nagasaki and to explore some of the implications of such an exercise.

\section{THE FREE-FIELD RANGE-EFFECTS DATA FOR HIROSHIMA AND NAGASAKI}

\section{A. GENERAL}

To scale the free-field effects parameters applicable to Hiroshima and Nagasaki, a 20 -kt yield was assumed to be representative for both cities. ${ }^{6}$ The burst height for Hiroshima was taken to be $1988 \mathrm{ft}$ ( 606 meters); ${ }^{\circ 1}$ that for Nagasaki, to be $1575 \mathrm{ft}$ ( 480 meters). ${ }^{61}$ All procedures were consistent with data given in the 1962 revision of The Effects of Nuclear Weapons. ${ }^{6}$ Slant range figures for initial ionizing** and thermal radiations were converted to ground range. Computations for the former were done using an air-density ratio applicable to each city and thermal figures were calculated for both $10-$ and 50-mile visibilities.

* Let the reader appreciate that the two curves applicable to primary blast also are labeled 6.4 and 12 psi incident overpressure; thus, they show how blast pressures vary with yield and range.

**See footnote, bottom of page 57 and Discussion. 


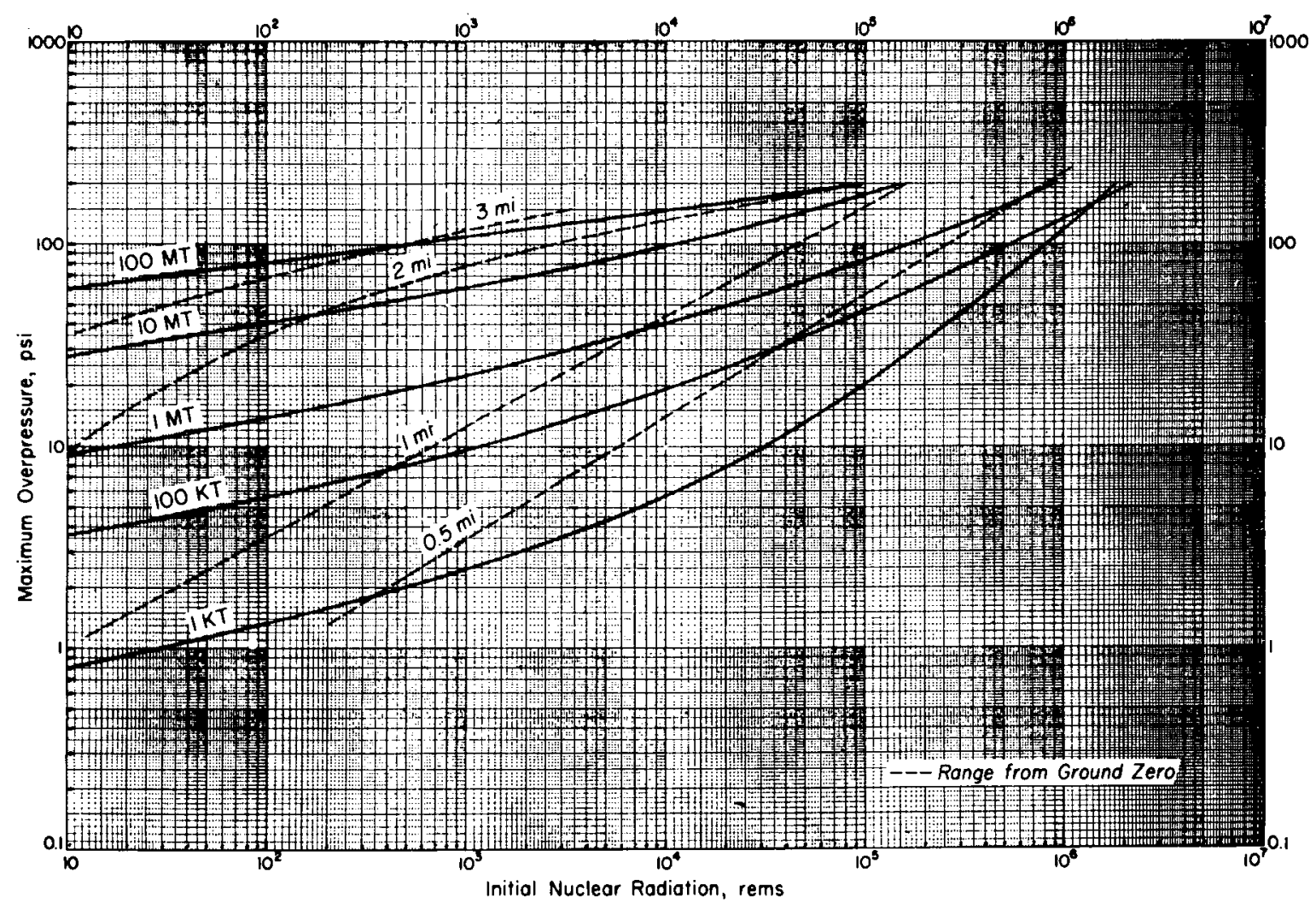

Figure 27 - Relationship between maximum overpressure and initial nuclear radiation for surface burst at sea level ambient pressure

\section{B. PRIMARY BLAST EFFECTS}

The scaled relationship betwe en maximal local static overpressure and range for Hiroshima is shown by the lower curve of Figure 28. The upper curve for reflected pressure was computed assuming a $90^{\circ}$-angle of incidence and it therefore represents the maximal possible increase in pressure due to reflection of the incident overpressure. The arrows pointing to the left and downward indicate the range inside which the noted primary blast effects would be expected to occur under two circumstances: namely, if the free-field incident overpressure represented the exposure pressure, then one reads the range below the tip of the arrow pointing left; if maximal pressure reflections applied because of appropriate conditions of exposure, one reads the range scale below the downward pointing arrows. Thus Figure 28 depicts graphically the application of the tentative biological criteria for primary blast effects that were set forth in Table 3.

Table 12 notes these again, includes the predicted ranges for each effect read from Figure 28, and presents values for initial nuclear and thermal radiations that were computed on a free-field basis at each range.

Figure 29 and Table 13 show similar data for Nagasaki. By way of comparison, the free-field pressures predicted at the hypocenter for Nagasaki (66 psi) are considerably higher than for Hiroshima ( $37 \mathrm{psi}$ ). At $0.54 \mathrm{mile}$, the overpressures were about the same for the two cities, namely, 16 psi. Inside this range pressures were higher for Nagasaki than for Hiroshima; outside this range, they were higher for Hiroshima than for Nagasaki. The crossover of the pressure curves is a consequence of the difference in burst height for the two explosions. 


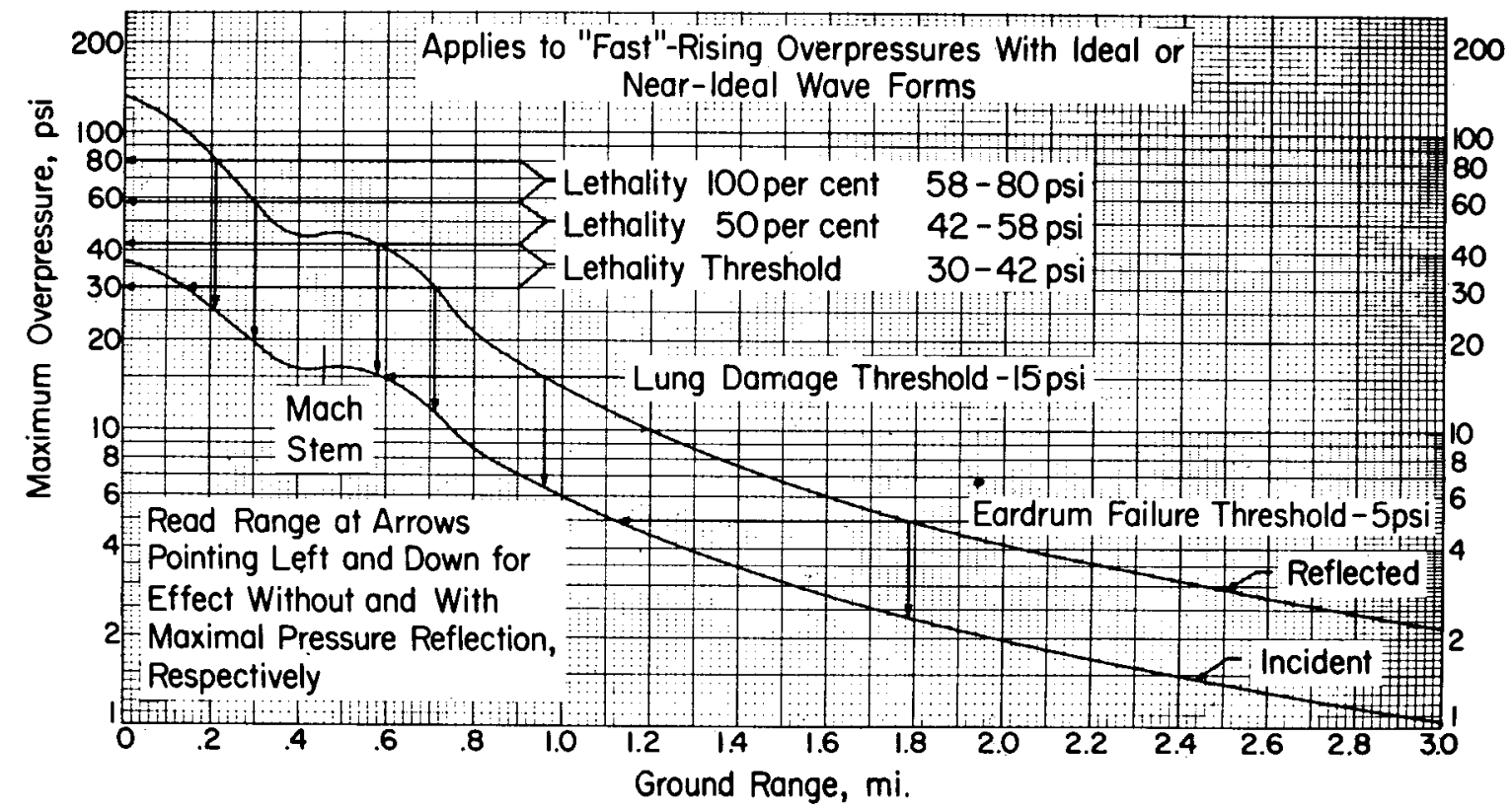

Figure 28 - Range-effect relationship for indicated primary blast damage $20-k t$ yield at Hiroshima burst height of $1988 \mathrm{ft}$ (606 meters) above sea-level terrain

TABLE 12 - RANGE FOR SPECIFIED PRIMARY BLAST HAZARDS AND ASSOCIATED FREE-FIELD EFFECTS PARAMETERS SCALED FOR 20-KT YIELD AT HIROSHIMA BURST HEIGHT OF 1988 FT (606 METERS) ABOVE SEA-LEVEL TERRAIN*

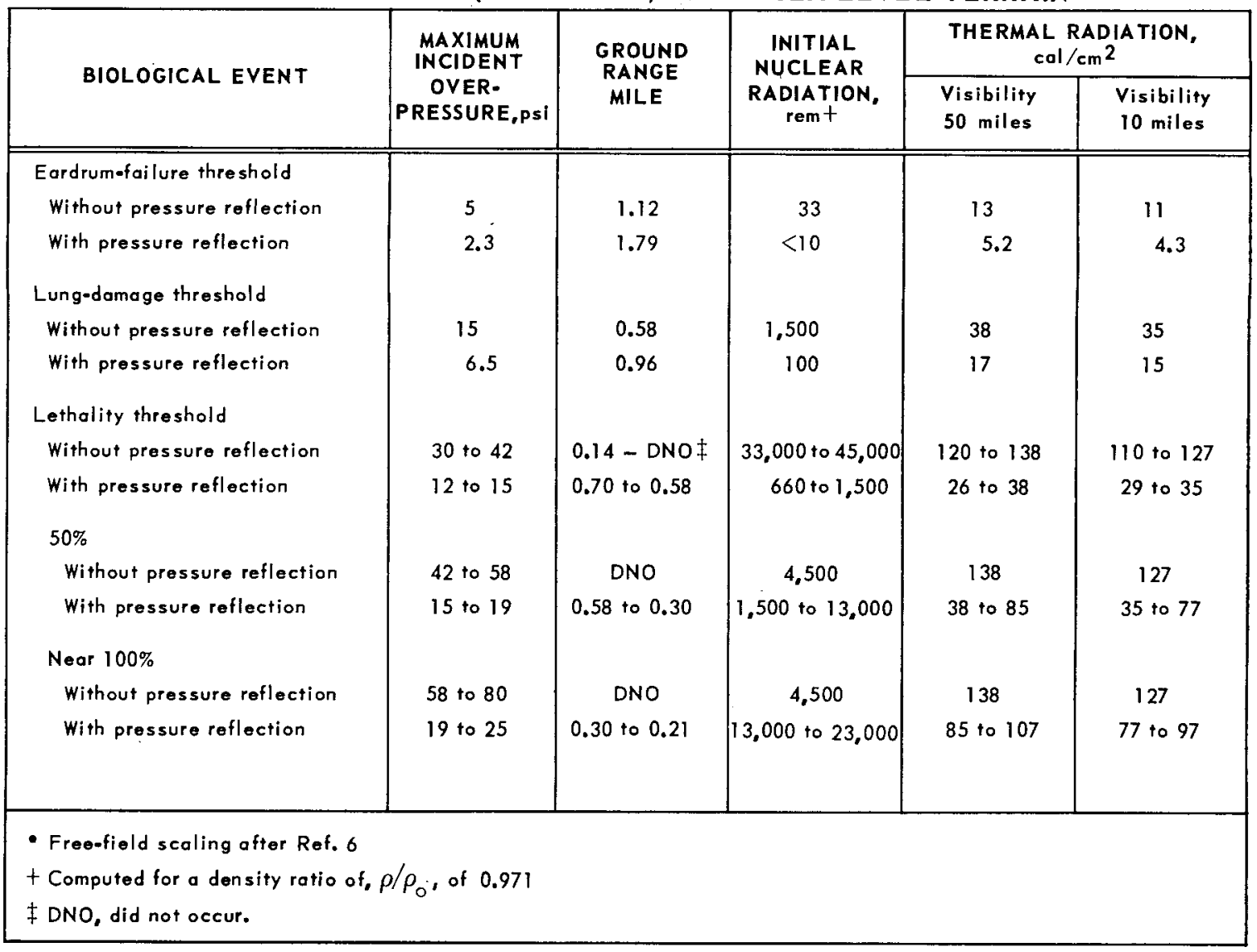




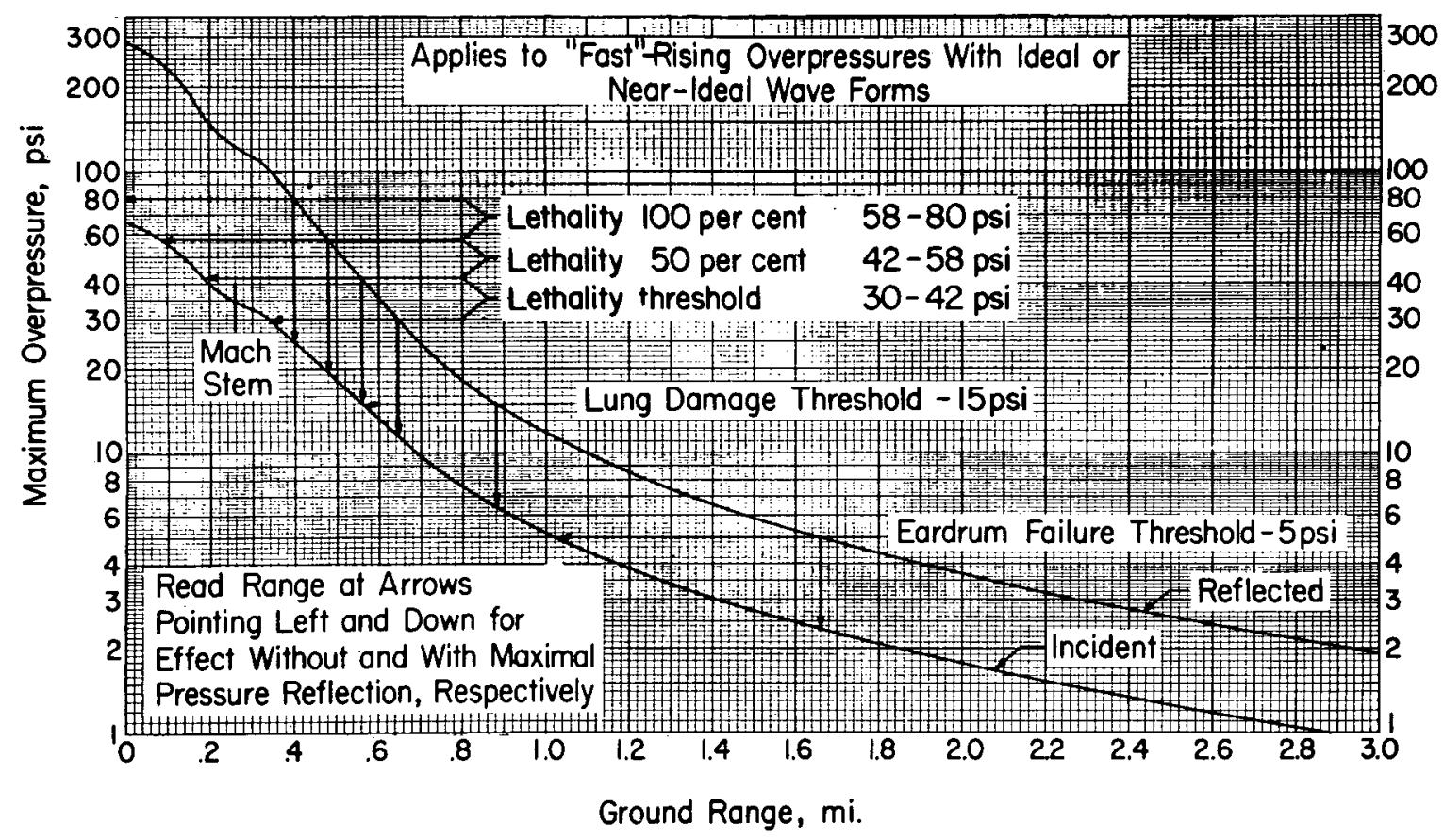

Figure 29 - Range-effect relationship for indicated primary blast damage $20-k t$ yield at Nagasaki burst height of $1575 \mathrm{ft}$ (480 meters) above sea-level terrain

TABLE 13 - RANGE FOR SPECIFIED PRIMARY BLAST HAZARDS AND ASSOCIATED FREE-FIELD EFFECTS PARAMETERS SCALED FOR 20-KT YIELD AT NAGASAKI BURST HEIGHT OF 1575 FT (480 METERS) ABOVE SEA-LEVEL TERRAIN *

\begin{tabular}{|c|c|c|c|c|c|}
\hline \multirow[b]{2}{*}{ BIOLOGICAL EVENT } & \multirow{2}{*}{$\begin{array}{l}\text { MAXIMUM } \\
\text { INCIDENT } \\
\text { OVER- } \\
\text { PRESSURE } \\
\text { PSi }\end{array}$} & \multirow{2}{*}{$\begin{array}{l}\text { GROUND } \\
\text { RANGE } \\
\text { MILE }\end{array}$} & \multirow{2}{*}{$\begin{array}{l}\text { INITIAL } \\
\text { NUCLEAR } \\
\text { RADIATION, } \\
\text { rem+ }\end{array}$} & \multicolumn{2}{|c|}{$\begin{array}{l}\text { THERMAL RADIATION, } \\
\mathrm{cal} / \mathrm{cm}^{2}\end{array}$} \\
\hline & & & & $\begin{array}{l}\text { Visibility } \\
50 \text { miles }\end{array}$ & $\begin{array}{l}\text { Visibility } \\
10 \text { miles }\end{array}$ \\
\hline $\begin{array}{l}\text { Eardrum-failure threshold } \\
\text { Without pressure reflection } \\
\text { With pressure reflection } \\
\text { Lung-domage threshold } \\
\text { Without pressure reflection } \\
\text { With pressure roflection } \\
\text { Letholity threshold } \\
\text { Without pressure reflection } \\
\text { With pressure reflection } \\
50 \% \\
\text { Without pressure reflection } \\
\text { With pressure reflection } \\
\text { Near } 100 \% \\
\text { Without pressure reflection } \\
\text { With pressure reflection }\end{array}$ & $\begin{array}{c}5 \\
2.3 \\
15 \\
6.4 \\
30 \text { to } 42 \\
12 \text { to } 15 \\
42 \text { to } 58 \\
15 \text { to } 19 \\
58 \text { to } 80 \\
19 \text { to } 25\end{array}$ & \begin{tabular}{|c|}
1.02 \\
1.66 \\
0.56 \\
0.88 \\
0.34 to 0.18 \\
0.65 to 0.56 \\
0.18 to 0.08 \\
0.56 to 0.48 \\
$0.08-0 N O+$ \\
0.48 to 0.40
\end{tabular} & $\begin{array}{c}68 \\
<10 \\
2,500 \\
190 \\
\\
17,000 \text { 10 } 61,000 \\
1,200 \text { to } 2,600 \\
61,000 \text { to } \\
>100,000 \\
2,600 \text { to } 5,100 \\
>100,000 \text { to } \\
>100,000 \\
5,100 \text { to } 10,000\end{array}$ & $\begin{array}{c}26 \\
6.2 \\
47 \\
22 \\
94 \text { to } 162 \\
37 \text { to } 47 \\
162 \text { to } 205 \\
47 \text { to } 59 \\
205 \text { to } 220 \\
59 \text { to } 77\end{array}$ & $\begin{array}{c}24 \\
5.2 \\
41 \\
18 \\
84 \text { to } 150 \\
27 \text { to } 41 \\
150 \text { to } 190 \\
41 \text { to } 52 \\
190 \text { to } 205 \\
52 \text { to } 69\end{array}$ \\
\hline $\begin{array}{l}\text { *Free-field scaling after Ref. } 6 \\
\text { +Computed for an aireden sity rati } \\
\ddagger D N O \text {, did not oecur. }\end{array}$ & $o / \rho_{0^{\prime}}$ of 0 & & & & \\
\hline
\end{tabular}


The range of mach-stem formation was about 0.26 mile ( 35 psi) at Nagasaki and 0.46 mile (16 psi) for Hiroshima. This is important because the upper floors of multistory buildings, located inside these ranges and therefore within the area of regular reflection, would receive at least two "fast"-rising pulses of overpressure; viz., first the incident (moving downward and outward) followed by the reflected shock (moving upward and outward), with the time between them being, among other things, functions of burst height, range and elevation above ground level. Buildings outside the range of mach-stem formation, providing the triple point is above the structure as the pressure wave passes, will receive a single shock moving outward perpendicular with the ground, unless the leading edge of the wave is disturbed by nearby structures and high temperatures radiating from the earth's surface

These facts mean that there may be critical differences in the rising phase of the pressure pulse on different floors of multistory buildings located inside the mach-stem range, whereas there is not likely to be such variation among the several floors of a similar building placed well outside this range; i.e., being on the ground floor of a structure within the area of regular reflection, all other factors being equal, could be more hazardous as far as primary blast is concerned than being on the top floor; in contrast, the pressure hazard would be similar on all floors of a structure located outside this region.

\section{TRANSLATIONAL EFFECTS}

\section{General}

Blast-induced translational phenomena involved in secondary and tertiary blast effects can be scaled to various explosive yields using the data of Bowen et al., ${ }^{58-60}$ and Fletcher et al. ${ }^{62.63}$ The velocity, gained by a translated object up to a maximum, is a function, among other things, of the displacem ent distance and the acceleration coefficient, $a=\frac{A}{m} \cdot C_{d} \mathrm{ft}^{2} / 1 \mathrm{~b}$; when $A=$ area presented to the wind, $m=$ mass and $C_{d}=$ drag coefficient. Figure 30 , computed for a 20-kt yield, shows the $\alpha$-velocity relationship - when the velocity is maximal - as it relates to various overpressures. ${ }^{50}$ The overpressures are expressed as multiples of the local ambient pressure. Similarly, Figure 31 gives the relationship between $a$ and displacement distance at various overpressures for a 20 -kt yield when the translational distance is that associated with maximal velocity. ${ }^{59}$

\section{The velocity-distance relations bip for 20-kt yield}

Thus it is necessary, when scaling translational velocities for a given yield, to specify the translational distance and the $a$ of interest as well as the overpressure. It is helpful, as an example, to note the velocity-distance relationship for a $165-1 \mathrm{~b}$ man using an "average" acceleration coefficient of $0.03 .{ }^{62} .64$ Figure 32 shows the computed data up to maximal velocity for various overpressures above a sea-level ambient produced by a 20 -kt detonation. The relationship shown is approximately applicable regardless of burst height, providing the pressure pulse is classical or near classical in form.

Similarly, Figure 33 gives the velocity-displacement-pressure relationship computed for a 10-gm fragment of double-strength window glass having an $a=0.72 \mathrm{ft}^{2} / \mathrm{lb}$. The overpressures specified refer to local static overpressures of classical or near-classical form, but in the computations it was assumed these pressures underwent maximal reflection, which course is consistent with available field and laboratory data. ${ }^{0}$ Thus the chart, strictly speaking, applies only to houses glazed with double-strength glass facing an oncoming blast wave. 


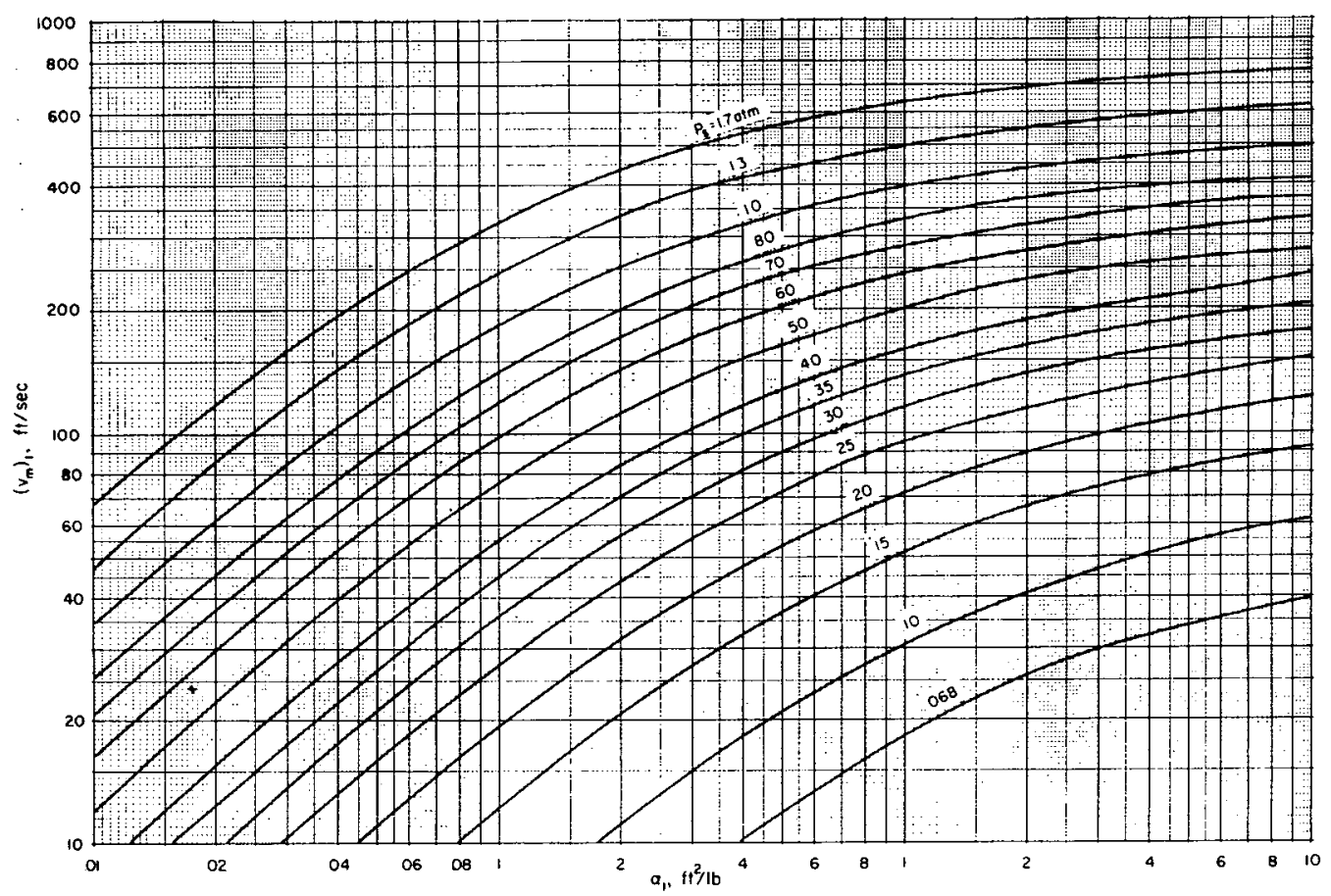

Figure 30 -Predicted maximum velocity as a function of acceleration coefficient (a) and shock overpressure computed for $W=20 \mathrm{kt}, \rho_{0}=14.7 \mathrm{psi}$, and $c_{0}=1117 \mathrm{ft} / \mathrm{sec}$. For other conditions use:

$$
a_{1}=a\left(\frac{1117}{c_{0}}\right)^{2}\left(\frac{\rho_{0}}{14.7}\right)^{\frac{2}{3}}\left(\frac{w}{20}\right)^{\frac{1}{3}} \quad v_{m}=\left(v_{m}\right)_{1} \frac{c_{0}}{1117}
$$

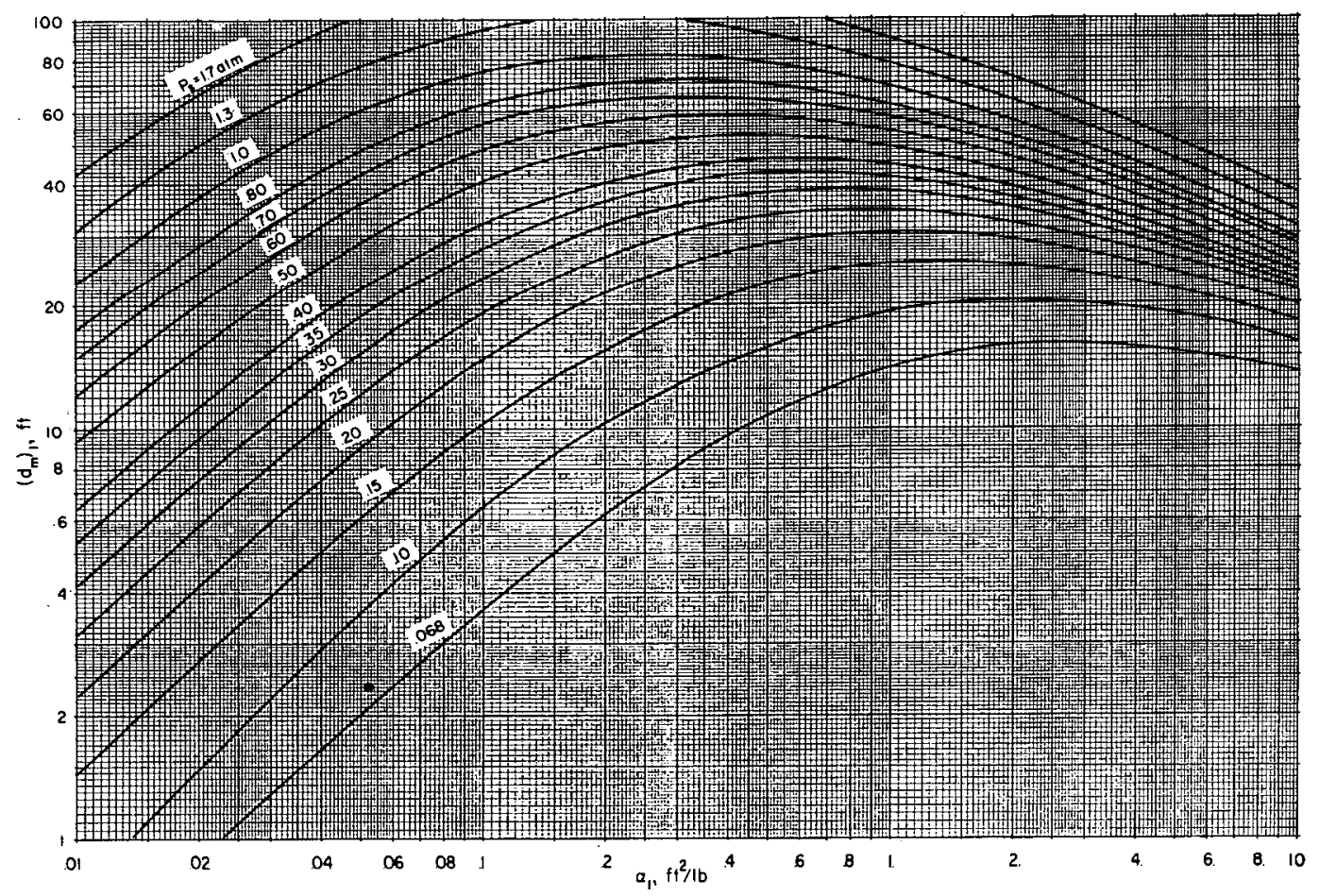

Figure 31 -Predicted displacement at maximum velocity as a function of acceleration coefficient $(a)$ and shock overpressure computed for $W=20 \mathrm{kt}, \rho_{0}=14.7 \mathrm{psi}$, and $c_{0}=1117 \mathrm{ft} / \mathrm{sec}$. For other conditions use:

$$
a_{1}=a\left(\frac{1117}{c_{0}}\right)^{2}\left(\frac{\rho_{0}}{14.7}\right)^{\frac{2}{3}}\left(\frac{\mathrm{w}}{20}\right)^{\frac{1}{3}} \quad d_{\mathrm{m}}=\left(\mathrm{d}_{\mathrm{m}}\right),\left(\frac{14.7 \mathrm{~W}}{P_{0} 20}\right) \frac{1}{3}
$$




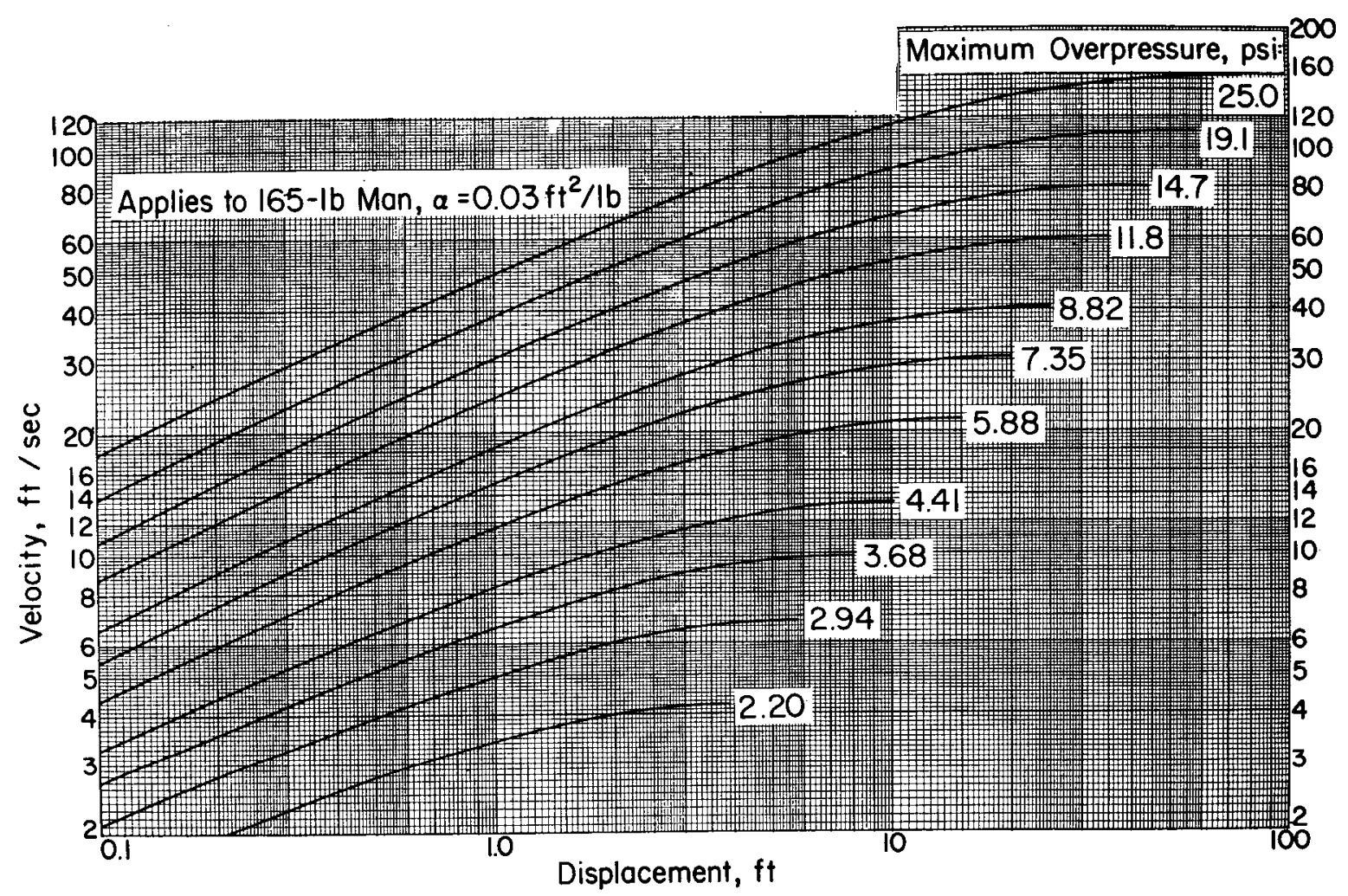

Figure 32 - The velocity-distance-pressure relationship computed for man-yield 20-kt

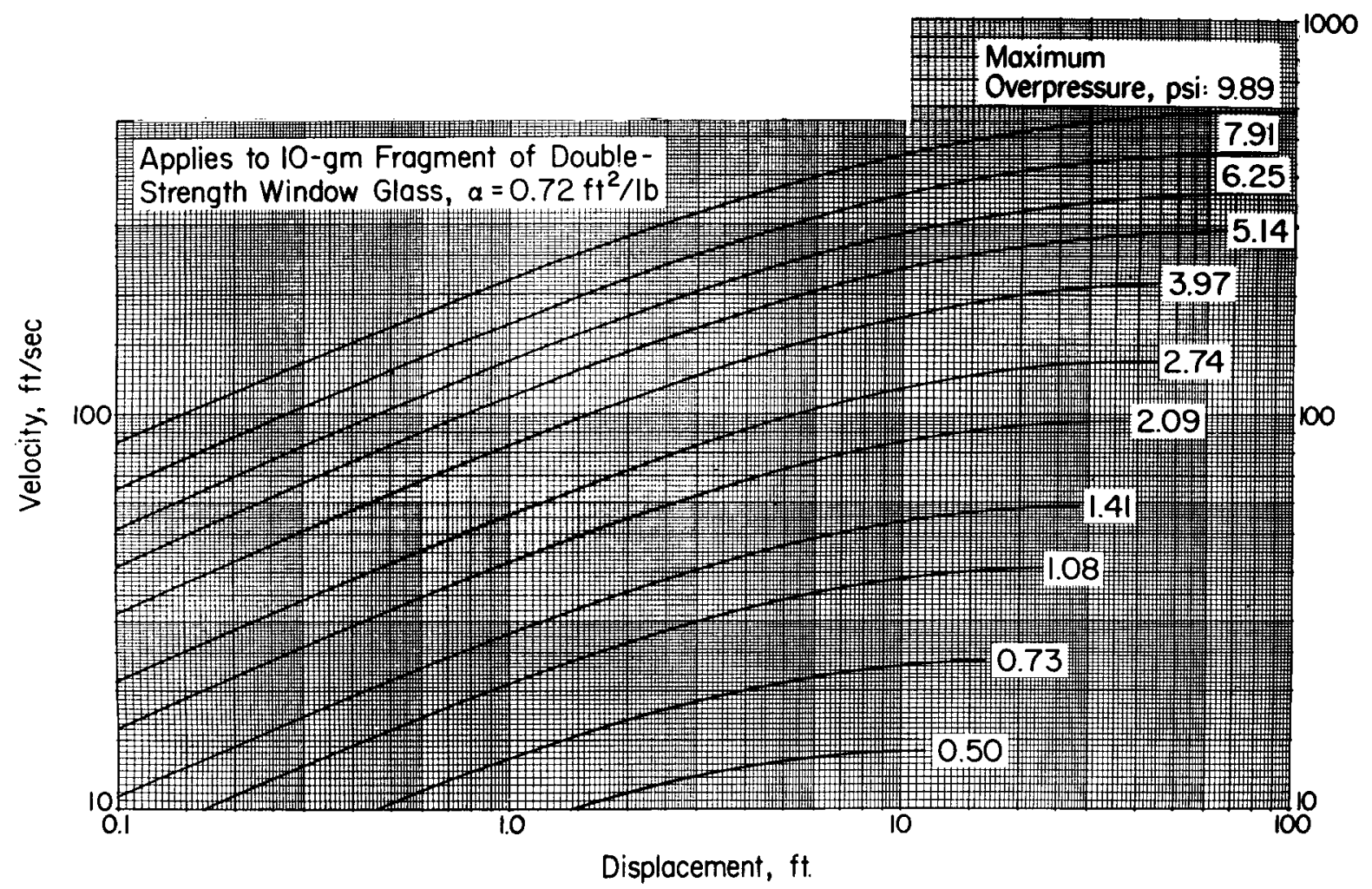

Figure 33 - The velocity-disfance-pressure relationship computed for window glass, yield 20kt 


\section{Secondary Effects}

To exemplify the application of the tentative criteria for secondary blast effects given in Table 8 for 10-gm glass fragments to the Hiroshima and Nagasaki explosions, a translational distance of $10 \mathrm{ft}$ was chosen arbitrarily and the velocities and overpressures corresponding to this distance were computed. The data are assembled in Tables 14 and 15 for Hiroshima and Nagasaki, respectively. Also shown are the ground ranges for each city inside which the specified effects could be expected, along with the free-field levels of initial ionizing and thermal radiations at the noted distances from the hypocenters.

In a previous study ${ }^{3}$ tentative biological criteria were established for a nonpenetrating stone missile of $10 \mathrm{lbs}\left(\alpha=0.02 \mathrm{ft}^{2} / \mathrm{lb}\right)$ assuming that the head was the critical organ. These are given in the first two columns of Tables 16 and 17 which include the scaled ground ranges for the specified effect applicable to Hiroshima and Nagasaki, respectively, as well as the free-field values for overpressure, initial nuclear and thermal radiations.

The curves at the top of Figures 34 and 35 show the velocity-range relationship for Hiroshima and Nagasaki, respectively, applicable to a $10-\mathrm{gm}$ glass fragment when the translational distance is fixed at $10 \mathrm{ft}$ and when it is taken to be that at which the attained velocity is maximal. By reading the range scale vertically below the tips of the arrows, one can obtain the ground range figures applicable to each of the effects noted in the chart.

\section{TABLE 14 - RANGE FOR SPECIFIED SECONDARY BLAST HAZARDS AND ASSOCIATED FREE-FIELD EFFECTS PARAMETERS SCALED FOR 20-KT YIELD AT HIROSHIMA BURST HEIGHT OF 1988 FT (606 METERS) ABOVE SEA-LEVEL TERRAIN*}

\begin{tabular}{|c|c|c|c|c|c|c|}
\hline \multirow{2}{*}{ BIOLOGICAL EVENT } & \multirow{2}{*}{ 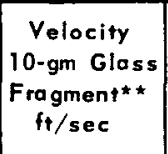 } & \multirow{2}{*}{$\begin{array}{l}\text { Ground } \\
\text { range, } \\
\text { mi }\end{array}$} & \multirow{2}{*}{$\begin{array}{c}\text { Maximum } \\
\text { incident } \\
\text { overpressure } \\
\text { psi }\end{array}$} & \multirow{2}{*}{$\begin{array}{l}\text { Initial } \\
\text { nuclear } \\
\text { radiation, } \\
\text { remt }\end{array}$} & \multicolumn{2}{|c|}{$\begin{array}{l}\text { THERMAL RADIATION, } \\
\text { VISI BILITY }\end{array}$} \\
\hline & & & & & $\begin{array}{c}50 \mathrm{mi} \\
\mathrm{cal} / \mathrm{cm}^{2}\end{array}$ & $\begin{array}{c}10 \mathrm{mi} \\
\mathrm{cal} / \mathrm{cm}^{2}\end{array}$ \\
\hline $\begin{array}{l}\text { Skin-laceration threshold } \\
\text { Serious wounds threshold } \\
50 \% \text {. } \\
\text { Neor } 100 \%\end{array}$ & $\begin{array}{r}50 \\
100 \\
180 \\
300\end{array}$ & $\begin{array}{l}2.70 \\
1.84 \\
1.30 \\
0.96\end{array}$ & $\begin{array}{l}1.25 \\
2.25 \\
3.90 \\
6.45\end{array}$ & $\begin{aligned}<10 \\
<10 \\
10 \\
100\end{aligned}$ & $\begin{array}{l}2.24 \\
4.90 \\
10 \\
17\end{array}$ & $\begin{array}{l}1.76 \\
4.00 \\
8 \\
15\end{array}$ \\
\hline \multicolumn{7}{|c|}{$\begin{array}{l}\text { Free-field scaling after Glasstone's } \Gamma \text { he Effects of Nuclear Weapons, } 1962 \text { Edition. } 6 \\
\text { Velocity-ronge relations from Tbe Effects of Nuclear Weapons, } 1962 \text { Ed ition } 6 \text { and CEX-58.9.5 } \\
\text { ** Velocity reached at a displacement of } 10 \mathrm{ft} \text { for } 10-\mathrm{gm} \text { double-strength window-glass fragments. } \\
\text { Acceleration coefficient, } a \text { of } 10-9 m \text { fragment }=0.72 \mathrm{ft}^{2} / \mathrm{lb} \text {. } \\
+ \text { Computed for an air-density ratio, } \rho / \rho_{0} \text { of } 0.971 \text {. }\end{array}$} \\
\hline
\end{tabular}

TABLE 15 - RANGE FOR SPECIFIED SECONDARY BLAST HAZARDS AND ASSOCIATED FREE-FIELD EFFECTS PARAMETERS SCALED FOR 20-KT YIELD AT NAGASAKI BURST HEIGHT OF 1575FT (480 METERS) ABOVE SEA-LEVEL TERRAIN*

\begin{tabular}{|c|c|c|c|c|c|c|}
\hline \multirow[b]{2}{*}{ BIOLOGICAL EVENT } & \multirow{2}{*}{$\begin{array}{c}\text { Velocity } \\
10 \cdot g m \text { Gloss } \\
\text { Fragments } \\
\mathrm{ft} / \mathrm{sec}\end{array}$} & \multirow{2}{*}{$\begin{array}{c}\text { Ground } \\
\text { ronge. } \\
\mathrm{mi}\end{array}$} & \multirow{2}{*}{$\begin{array}{c}\text { Maximum } \\
\text { inciden } \dagger \\
\text { overpressure } \\
\text { psi }\end{array}$} & \multirow{2}{*}{$\begin{array}{c}\text { Initial } \\
\text { nuclear } \\
\text { radiation, } \\
\text { remt }\end{array}$} & \multicolumn{2}{|c|}{$\begin{array}{c}\text { THE RMAL RADIATION, } \\
\text { VISIBILITY }\end{array}$} \\
\hline & & & & & $\begin{array}{c}50 \mathrm{mi} \\
\mathrm{col} / \mathrm{cm}^{2}\end{array}$ & $\begin{array}{c}10 \mathrm{mi} \\
\mathrm{cal} / \mathrm{cm}^{2}\end{array}$ \\
\hline Skin-laceration threshold & 50 & 2.51 & 1.25 & $<10$ & 2.63 & 2.08 \\
\hline Serious wounds threshold & 100 & 1.70 & 2.25 & $<10$ & 5.80 & 4.80 \\
\hline $50 \%$ & 180 & 1.19 & 3.90 & 20 & 11.7 & 10.0 \\
\hline Near $100 \%$ & 300 & .88 & 6.45 & 190 & 21.5 & 18.4 \\
\hline \multicolumn{7}{|c|}{$\begin{array}{l}\text { * Free-field scaling after Glasstone's The Effects of Nuclear Weapons, } 1962 \text { Edition. } \\
\text { Velocity-range relations from The Effects of Nuclear Weapons, } 1962 \text { Edition }{ }^{6} \text { and CEX-58.9.59 } \\
\text { * Velocity reached at a displacement of } 10 \mathrm{ft} \text { for } 10 . \mathrm{gm} \text { double-strength window-gloss fragments. } \\
\text { Acceleration coefficient, } a \text {, of } 10-9 \mathrm{~m} \text { fragment }=0.72 \mathrm{ft} 2 / \mathrm{lb} \text {. } \\
+ \text { Computed for an air-density retio, } \rho / \rho_{0}, \text { of } 0.994 .\end{array}$} \\
\hline
\end{tabular}


TABLE 16 - RANGE FOR SPECIFIED SECONDARY BLAST HAZARDS AND ASSOCIATED FREE-FIELD EFFECTS PARAMETERS - 20-KT YIELD AT HIROSHIMA BURST HEIGH T OF 1988 FT (606 METERS) ABOVE SEA-LEVEL TERRAIN*

\begin{tabular}{|c|c|c|c|c|c|c|}
\hline \multirow{2}{*}{$\begin{array}{l}\text { BIOLOGICAL } \\
\text { EVENT }\end{array}$} & \multirow{2}{*}{$\begin{array}{l}\text { Velocity } \\
\text { for } 10-16 \\
\text { Stone } * * \\
\text { ft/sec }\end{array}$} & \multirow{2}{*}{$\begin{array}{c}\text { Ground } \\
\text { range, } \\
\text { mi }\end{array}$} & \multirow{2}{*}{$\begin{array}{l}\text { Maximum } \\
\text { incident } \\
\text { overpressure } \\
\text { psi }\end{array}$} & \multirow{2}{*}{$\begin{array}{l}\text { Initial } \\
\text { nuclear } \\
\text { radiation, } \\
\text { remt }\end{array}$} & \multicolumn{2}{|c|}{$\begin{array}{c}\text { THERMAL RADIATION, } \\
\text { VISIBILITY }\end{array}$} \\
\hline & & & & & $\begin{array}{l}50 \mathrm{mi} \\
\mathrm{col} / \mathrm{cm}^{2}\end{array}$ & $\begin{array}{l}10 \mathrm{mi} \\
\mathrm{col} / \mathrm{cm}^{2}\end{array}$ \\
\hline \multicolumn{7}{|c|}{ Cerebral eoncussion } \\
\hline Mostly safe & 10 & 1.20 & 4.50 & 19 & 11.3 & 9.6 \\
\hline Threshold & 15 & 1.02 & 5.78 & 66 & 15.1 & 13.1 \\
\hline \multicolumn{7}{|l|}{ Skulf fracture } \\
\hline Mostly safe & 10 & 1.20 & 4.50 & 19 & 11.3 & 9.6 \\
\hline Threshold & 15 & 1.02 & 5.78 & 66 & 15.1 & 13.1 \\
\hline Near $100 \%$ & 23 & 0.87 & 7.50 & 190 & 20.0 & 17.6 \\
\hline \multicolumn{7}{|c|}{$\begin{array}{l}\text { - Free-field scaling according to The Effects of Nuclear Weapons, } 1962 \text { Edition. }{ }^{6} \\
\text { Velocity-range relations from The Effects of Nuclear Weapons, } 1962 \text { Edition. }{ }^{6} \text { and CEX-58.9.59 } \\
\text { ** Maximum velocity attained. Acceleration coefficient, } \alpha \text {, of } 10-1 \mathrm{~b} \text { stone }=.02 \mathrm{ft}^{2} / \mathrm{lb} \text {. } \\
\text { + Computed for an air-density ratio, } \rho / \rho_{0} \text { of of } 0.971 \text {. }\end{array}$} \\
\hline
\end{tabular}

TABLE 17 - RANGE FOR SPECIFIED SECONDARY BLAST HAZARDS AND ASSOCIATED FREE-FIELD EFFECTS PARAMETERS - 20-KT YIELD AT NAGASAKI BURST HEIGHT OF 1575 FT (480 METERS) ABOVE SEA-LEVEL TERRAIN*

\begin{tabular}{|c|c|c|c|c|c|c|}
\hline \multirow{2}{*}{$\begin{array}{l}\text { BIOLOGICAL } \\
\text { EVENT }\end{array}$} & \multirow{2}{*}{$\begin{array}{l}\text { Velocity } \\
\text { for 10-1b } \\
\text { Stone } \star \star \\
f t / \text { sec }\end{array}$} & \multirow{2}{*}{$\begin{array}{c}\text { Ground } \\
\text { range, } \\
\mathrm{mi}\end{array}$} & \multirow{2}{*}{$\begin{array}{l}\text { Maximum } \\
\text { incident } \\
\text { overpressure } \\
\text { psi }\end{array}$} & \multirow{2}{*}{$\begin{array}{l}\text { Initial } \\
\text { nuclear } \\
\text { radiation } \\
\text { remt }\end{array}$} & \multicolumn{2}{|c|}{$\begin{array}{c}\text { THERMAL RADIATION, } \\
\text { VISIBILITY } \\
\end{array}$} \\
\hline & & & & & $\underset{\mathrm{cal} / \mathrm{cm}^{2}}{50 \mathrm{mi}}$ & $\begin{array}{l}10 \mathrm{mi} \\
\mathrm{cal} / \mathrm{cm}^{2}\end{array}$ \\
\hline \multicolumn{7}{|l|}{ Cerebral concussion } \\
\hline Mostly safo & 10 & 1.09 & 4.50 & 42 & 14.0 & 12.0 \\
\hline Threshold & 15 & 0.93 & 5.78 & 130 & 19.3 & 16.6 \\
\hline \multicolumn{7}{|l|}{ Skull frocture } \\
\hline Mostly sofe & 10 & 1.09 & 4.50 & 42 & 14.0 & 12.0 \\
\hline Threshold & 15 & 0.93 & $5.7 i s$ & 130 & 19.3 & 16.6 \\
\hline Near $100 \%$ & 23 & 0.80 & 7.50 & 360 & 25.9 & 22.0 \\
\hline \multicolumn{7}{|c|}{$\begin{array}{l}\text { * Free-field scaling according to The Effects of Nuclear Weapons, } 1962 \text { Edition. }{ }^{6} \\
\text { Velocity-range relations from The Effects of Nuclear Weapons, } 1962 \text { Edition, } 6 \text { and CEX-58.9.50 } \\
\text { * Moximum velocity attained. Acceleration coefficient, } \alpha \text {, of } 10-1 \mathrm{lb} \text { stone }=.02 \mathrm{ft} 2 / \mathrm{lb} \text {. } \\
+ \text { Computed for an air-density ratio, } \rho / \rho_{0} \text {, of } 0.994 \text {. }\end{array}$} \\
\hline
\end{tabular}




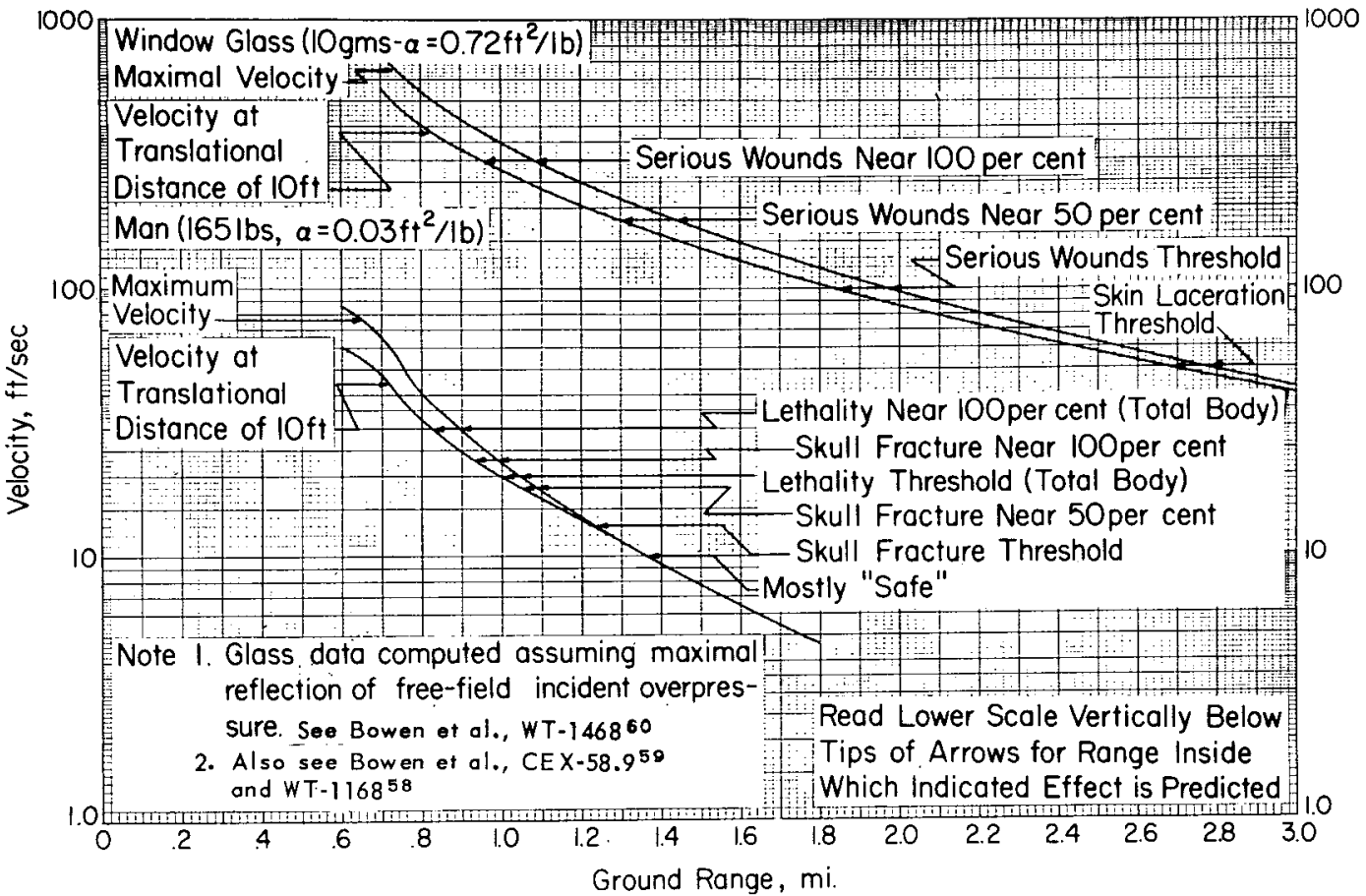

Figure 34 - The velocity-range relationship for translational effects 20-kt yield at Hiroshima burst height of $1988 \mathrm{ft}$ (606 meters)

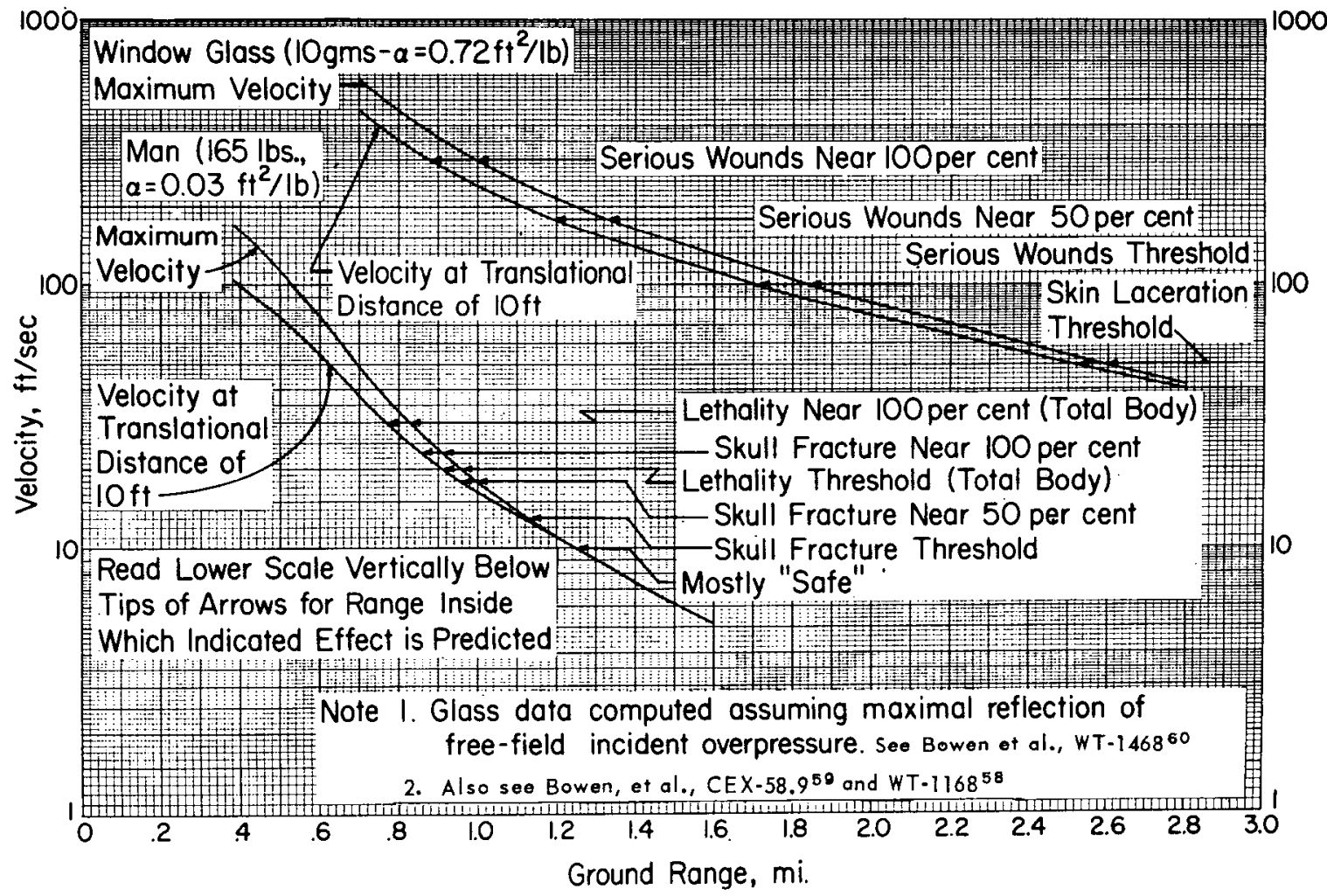

Figure 35 - The velocity-range relationship for translational effects 20-kt yield at Nagasaki burst height of $1575 \mathrm{ft}$ (480 meters) 


\section{Tertiary Blast Effects}

Tables 18 and 19, noting the tentative biological criteria given above in Table 10 for different levels of damage associated with impact at various translational velocities, contain the scaled ranges for Hiroshima and Nagasaki, respectively, inside which the specified hazards are potentially possible if the translational distances are "fixed" at $10 \mathrm{ft}$ for a $165-1 \mathrm{~b}$ man. The tables also give the free-field values for maximal local static overpressure, thermal and initial nuclear radiation.

The lower curves in Figures 34 and 35 for Hiroshima and Nagasaki, respectively, show the tentative criteria for impact hazards as they relate to the velocity-range diagram for the two cities. The computations were made for translational distances at maximal velocity and at $10 \mathrm{ft}$ of travel.

\section{TABLE 18 - RANGE FOR SPECIFIED TERTIARY BLAST HAZARDS AND ASSOCIATED FREE-FIELD EFFECTS PARAMETERS-20-KT YIELD AT HIROSHIMA BURST HEIGHT OF 1988 FT (606 METERS) ABOVE SEA-LEVEL TERRAIN*}

\begin{tabular}{|c|c|c|c|c|c|c|}
\hline \multirow{2}{*}{ BIOLOGICAL EVENT+ } & \multirow{2}{*}{$\begin{array}{l}\text { Velocity } \\
\text { for } \\
165-\mathrm{lb} \\
\text { Man }{ }^{\star \star} \\
\mathrm{ft} / \text { sec }\end{array}$} & \multirow{2}{*}{$\begin{array}{l}\text { Ground } \\
\text { range, } \\
\text { mi }\end{array}$} & \multirow{2}{*}{$\begin{array}{c}\text { Maximum } \\
\text { incident } \\
\text { overpressure } \\
\text { psi }\end{array}$} & \multirow{2}{*}{$\begin{array}{l}\text { Initial } \\
\text { nuclear } \\
\text { radiation } \\
\text { remt+ }\end{array}$} & \multicolumn{2}{|c|}{$\begin{array}{c}\text { THERMAL RADIATION, } \\
\text { VISIBILITY }\end{array}$} \\
\hline & & & & & $\underset{\mathrm{cal} / \mathrm{cm}^{2}}{50 \mathrm{mi}}$ & $\begin{array}{c}10 \mathrm{mi} \\
\mathrm{cal} / \mathrm{cm} 2\end{array}$ \\
\hline \multicolumn{7}{|l|}{ Total-body impact } \\
\hline Mostly safe & 10 & 1.37 & 3.6 & $<10$ & 8.8 & 7.4 \\
\hline \multicolumn{7}{|l|}{ Lethality } \\
\hline Threshold & 20 & 1.00 & 6.0 & 75 & 16 & 14 \\
\hline $50 \%$ & 26 & 0.89 & 7.3 & 160 & 19 & 17 \\
\hline Near $100 \%$ & 30 & 0.82 & 8.2 & 270 & 22 & 20 \\
\hline \multicolumn{7}{|l|}{ Skull fracture } \\
\hline Mostly safe & 10 & 1.37 & 3.6 & $<10$ & 8.8 & 7.4 \\
\hline Threshold & 13 & 1.22 & 4.3 & 17 & 11 & 9.2 \\
\hline $50 \%$ & 18 & 1.05 & 5.5 & 54 & 14 & 12 \\
\hline Near $100 \%$ & 23 & 0.93 & 6.7 & 120 & 18 & 16 \\
\hline \multicolumn{7}{|c|}{$\begin{array}{l}\text { * Free-field scaling according to The Effects of Nuclear Weapons, } 1962 \text { Edition. }{ }^{6} \\
\text { Velocity-range relations from The Effects of Nuclear Weapons, } 1962 \text { Edition, } 6 \text { and CEX-58.9.59 } \\
+ \text { Applies to uncontrolled impact with a hard flat surface. } \\
\star \star \text { Velocify reached at a displacement of } 10 \mathrm{ft} \text {. Average acceleration coefficient, } \alpha \text {, of } 165-\mathrm{lb} \text { tumbling man }=.03 \mathrm{ft} 2 / \mathrm{b} \text {. } \\
++ \text { Computed for on air-density ratio, } \rho / \rho_{\mathrm{O}} \text {, of } 0.971 \text {. }\end{array}$} \\
\hline
\end{tabular}


TABLE 19 - RANGE FOR SPECIFIED TERTIARY BLAST HAZARDS AND ASSOCIATED FREEFIELD EFFECTS PARAMETERS-20-KT YIELD AT NAGASAKI BURST HEIGHT OF 1575 FT (480 METERS) ABOVE SEA-LEVEL TERRAIN*

\begin{tabular}{|c|c|c|c|c|c|c|}
\hline \multirow{2}{*}{ BIOLOGICAL EVENT** } & \multirow{2}{*}{$\begin{array}{l}\text { Velocity } \\
\text { for } \\
165 \cdot 16 \\
\text { Mant } \\
\mathrm{ft} / \text { sec }\end{array}$} & \multirow{2}{*}{$\begin{array}{l}\text { Ground } \\
\text { range, } \\
\text { mi }\end{array}$} & \multirow{2}{*}{$\begin{array}{c}\text { Maximum } \\
\text { incident } \\
\text { overpressure } \\
\text { psi }\end{array}$} & \multirow{2}{*}{$\begin{array}{l}\text { Initial } \\
\text { nuclear } \\
\text { radiation } \\
\text { rem+t }\end{array}$} & \multicolumn{2}{|c|}{$\begin{array}{c}\text { THERMAL RADIATION } \\
\text { VISIBILITY }\end{array}$} \\
\hline & & & & & $\begin{array}{c}50 \mathrm{mi} \\
\mathrm{cal} / \mathrm{cm}^{2}\end{array}$ & $\begin{array}{l}10 \mathrm{mi} \\
\mathrm{col} / \mathrm{cm}^{2}\end{array}$ \\
\hline \multicolumn{7}{|l|}{ Total=body impact } \\
\hline Mostly sofe & 10 & 1.25 & 3.6 & 13 & 11 & 9.1 \\
\hline \multicolumn{7}{|l|}{ Lethality } \\
\hline Threshold & 20 & 0.91 & 6.0 & 150 & 20 & 17 \\
\hline $50 \%$ & 26 & 0.81 & 7.3 & 340 & 25 & 22 \\
\hline Near $100 \%$ & 30 & 0.77 & 8.2 & 450 & 28 & 24 \\
\hline \multicolumn{7}{|l|}{ Skull frocture } \\
\hline Mostly safe & 10 & 1.25 & 3.6 & 13 & 11 & 9.1 \\
\hline Threshold & 13 & 1.12 & 4.3 & 34 & 13 & 11 \\
\hline $50 \%$ & 18 & 0.96 & 5.5 & 110 & 18 & 16 \\
\hline Neor $100 \%$ & 23 & 0.85 & 6.7 & 240 & 23 & 20 \\
\hline $\begin{array}{l}\text { * Free-field scaling according } \\
\text { Velocity-range relations from } \\
\text { * Applies to uncontrolled impa } \\
\text { + Velocity reached at a displa } \\
++ \text { Computed for an air-density }\end{array}$ & $\begin{array}{l}\text { ffects of } \\
\text { ects of } N u \\
\text { hard flats } \\
\text { f loft. Ave } \\
\text { Dor of } 0.99\end{array}$ & $\begin{array}{l}\text { ear Wea } \\
r \text { Weape } \\
\text { ce. } \\
\text { occele }\end{array}$ & $\begin{array}{l}\text { s, } 1962 \text { Editi } \\
1962 \text { Edition } \\
\text { on coefficien }\end{array}$ & $\begin{array}{l}.6 \\
\text { and CEX- } \\
\alpha \text {, of } 165\end{array}$ & 50 & lb. \\
\hline
\end{tabular}

\section{SUMMARY OF COMPARATIVE FREE-FIELD EFFECTS DATA}

To assess the comparative nature of the free-field effects as they vary with range from the hypocenters of the Japanese explosions, Tables 20 and 21 were assembled from the tabular data presented above. Starting at the hypocenters and moving outward, the ranges inside which each of the specified hazards was predicted are noted along with the respective free-field values for the major effects parameters. The scaled ranges for first degree $\left(2.5 \mathrm{cal} / \mathrm{cm}^{2}\right)$ and $s e c o n d$ degree $\left(4.5 \mathrm{cal} / \mathrm{cm}^{2}\right)$ bums were included as they were for 100 and $200 \mathrm{rem}$, the latter being taken as the threshold dose for acute radiation sickness.

\section{Primary Blast}

Since significant primary blast injury is so characteristically associated with early lethality, it is important to note that the potential for acute death from exposure to pressure variations extended out to 0.14 and 0.70 miles at Hiroshima, depending upon whether the free-field incident or maximal reflected pressures represented the challenge. At Nagasaki the corresponding ranges were 0.34 and 0.65 miles. The data are summarized in Table 22 for the two cities along with the ranges for the threshold of lung injuries. The latter are important because individuals with blast-injured lungs tolerate activity poorly; i.e., exercise is likely to precipitate a fatal outcome in cases that otherwise might survive.

A study of Table 22 indicates that free-field thermal fluxes in excess of $15-18$ $\mathrm{cal} / \mathrm{cm}^{2}$ existed inside the ranges over which a serious potential primary blast hazard is predicted. Also it is interesting and significant that initial nuclear radiation levels of 100 and 190 rem are scaled for the ranges predicted for the threshold of lung injury in the case of Hiroshima and Nagasaki, respectively, if maximal pressure reflection is as sumed. 
TABLE 20 - COMPARATIVE BIOLOGICAL EFFECTS AS A FUNCTION OF RANGE FOR A 20-KT YIELD SCALED FOR HIROSHIMA BURST HEIGHT OF 1988FT (606 METERS)ABOVE SEA-LEVEL TERRAIN

\begin{tabular}{|c|c|c|c|c|c|}
\hline \multirow{2}{*}{ BIOLOGICAL EVENT OR EFFECT } & \multirow{2}{*}{$\begin{array}{l}\text { Ground } \\
\text { range, } \\
\text { in } \mathrm{mi}\end{array}$} & \multirow{2}{*}{$\begin{array}{l}\text { Maximum } \\
\text { pressure, } \\
\text { in psi }\end{array}$} & \multirow{2}{*}{$\begin{array}{l}\text { Initial } \\
\text { nuclear } \\
\text { radiotion, } \\
\text { rem }\end{array}$} & \multicolumn{2}{|c|}{$\begin{array}{l}\text { THERMAL RADIATION, } \\
\text { VISIBILITY }\end{array}$} \\
\hline & & & & $\begin{array}{l}50 \mathrm{mi} \\
\mathrm{cal} / \mathrm{cm}^{2}\end{array}$ & $\begin{array}{l}10 \mathrm{mi} \\
\mathrm{cal} / \mathrm{cm}^{2}\end{array}$ \\
\hline Effects at hypocenter & 0 & 37 & 45,000 & 138 & 127 \\
\hline $\begin{array}{l}\text { Primory blast: !ethality, threshold without } \\
\text { pressure reflection }\end{array}$ & 0.14 & 30 & 33,000 & 120 & 110 \\
\hline Primary blast: Lethality near 100 per cent with & 0.21 & 25 & 23,000 & 107 & 97 \\
\hline pressure reflection & 0.30 & 19 & 13,000 & 85 & 77 \\
\hline Primary blast: Lethality near 50 per cent with & 0.30 & 19 & 13,000 & 85 & 77 \\
\hline pressure reflection & 0.58 & 15 & 1,500 & 38 & 35 \\
\hline Lung damage: Threshold without pressure reflection & 0.58 & 15 & 1,500 & 38 & 35 \\
\hline Primary blast: Lethality, threshold, maximum & 0.58 & 15 & 1,500 & 38 & 35 \\
\hline pressure reflection & 0.70 & 12 & 660 & 29 & 26 \\
\hline Impact total body: Lethality near 100 per cent & 0.82 & 8.2 & 270 & 22 & 20 \\
\hline Skull frocture near 100 per cent ( $10 \mathrm{lb}$ stone) & 0.87 & 7.5 & 190 & 20 & 18 \\
\hline Impact total body lethality near 50 per cent & 0.89 & 7.3 & 160 & 19 & 17 \\
\hline Skull fracture, impact near 100 per cent & 0.93 & 6.7 & 120 & 18 & 16 \\
\hline Initial nuclear radiation: injury threshold & 0.96 & 6.5 & 100 & 17 & 15 \\
\hline Serious wounds from 10 -gm glass fragments $100 \%$ & 0.96 & 6.5 & 100 & 17 & 15 \\
\hline Lung damage, threshold with pressure reflection & 0.96 & 6.5 & 100 & 17 & 15 \\
\hline Impoct total body lethality, threshold & 1.00 & 6.0 & 75 & 16 & 14 \\
\hline Skull fracture, threshold ( $10 \mathrm{lb}$ stone) & 1.02 & 5.8 & 66 & 15 & 13 \\
\hline Cerebral concussion, threshold ( $10 \mathrm{lb}$ stone) & 1.02 & 5.8 & 66 & 15 & 13 \\
\hline Skull fracture, impact near 50 per cent & 1.05 & 5.5 & 54 & 14 & 12 \\
\hline Eardrum failure threshold without & & & & & \\
\hline pressure reflection & 1.12 & 5.0 & 33 & 13 & 11 \\
\hline Skull frocture, mostly "safe" (10 lb stone) & 1.20 & 4.5 & 19 & 11 & 10 \\
\hline Cerebral concussion, mostly "safe" (10 lb stone) & 1.20 & 4.5 & 19 & 11 & 10 \\
\hline Skull frocture, impoct threshold & 1.22 & 4.3 & 17 & 11 & 9 \\
\hline Serious wounds from 10-gm glass fragments, near $50 \%$ & 1.30 & 3.90 & 10 & 10 & 8 \\
\hline Skull fracture, impact mostly "safe" & 1.37 & 3.6 & $<10$ & 9 & 7 \\
\hline Second degree burns & 1.74 & 2.4 & $<10$ & & 4.5 \\
\hline Eardrum failure, threshold with pressure reflection & 1.79 & 2.3 & $<10$ & 5 & 4 \\
\hline Serious wounds from $10-$ gm glass fragments, threshold & 1.84 & 2.3 & $<10$ & 5 & 4 \\
\hline Second degree burns & 1.90 & 2.15 & $<10$ & 4.5 & \\
\hline First degree burns & 2.31 & 1.8 & $<10$ & 2.5 & \\
\hline & 2.56 & 1.35 & $<10$ & & 2.5 \\
\hline Skin laceration s from 10-gm glass fragments, the reshoid & 2.7 & 1.3 & $<10$ & 2 & $1 . \dot{8}$ \\
\hline
\end{tabular}


TABLE 21 - COMPARATIVE BIOLOGICAL EFFECTS AS A FUNCTION OF RANGE FOR A 20-KT YIELD SCALED FOR NAGASAKI BURST HEIGHT OF 1575 FT (480 METERS) ABOVE SEA-LEVEL TERRAIN

\begin{tabular}{|c|c|c|c|c|c|}
\hline \multirow{2}{*}{ BIOLOGICAL EVENT OR EFFECT } & \multirow{2}{*}{$\begin{array}{l}\text { Ground } \\
\text { ronge, } \\
\text { in mi }\end{array}$} & \multirow{2}{*}{$\begin{array}{l}\text { Maximum } \\
\text { pressure, } \\
\text { in psi }\end{array}$} & \multirow{2}{*}{$\begin{array}{l}\text { Initial } \\
\text { nuclear } \\
\text { radiation, } \\
\text { rem }\end{array}$} & \multicolumn{2}{|c|}{$\begin{array}{l}\text { THERMAL RADIATION, } \\
\text { VISIBILITY }\end{array}$} \\
\hline & & & & $\begin{array}{c}50 \mathrm{mi} \\
\mathrm{cal} / \mathrm{cm}^{2}\end{array}$ & $\mathrm{col} / \mathrm{cm}_{\mathrm{cm}}^{10 \mathrm{mi}}$ \\
\hline Effects of hroocenter & 0 & 66 & 122,000 & 220 & 204 \\
\hline $\begin{array}{l}\text { Primary blast lethality near } 100 \text { per cent without } \\
\text { pressure reflection }\end{array}$ & 0.08 & 58 & 100,000 & 205 & 190 \\
\hline Primary blast lethality near 50 per cent wi thout & 0.08 & 58 & 100,000 & 205 & 190 \\
\hline pressure reflection & 0.18 & 42 & 58,000 & 162 & 150 \\
\hline Primary blast lethality threshold without & 0.18 & 42 & 58,000 & 162 & 150 \\
\hline pressure reflection & 0.34 & 30 & 17,000 & 94 & 84 \\
\hline Primary blast lethality near 100 per cent with & 0.40 & 25 & 10,000 & 77 & 69 \\
\hline pressure reflection & 0.48 & 19 & 5,100 & 59 & 52 \\
\hline Primary blast lethality near 50 percent with & 0.48 & 19 & 5,100 & 59 & 52 \\
\hline pressure reflection & 0.56 & 15 & 2,600 & 47 & 41 \\
\hline $\begin{array}{l}\text { Primary blast lung injury threshold without } \\
\text { pressure reflection }\end{array}$ & 0.56 & 15 & 2,600 & 47 & 41 \\
\hline Primary blast lethalify threshold with maximum & 0.56 & 15 & 2,600 & 47 & 41 \\
\hline pressure reflection & 0.65 & 12 & 1,200 & 37 & 27 \\
\hline Impact - total body lethality near 100 per cent & 0.77 & 8.2 & 450 & 28 & 24 \\
\hline Skull fracture $-10 \cdot 1 \mathrm{~b}$ stone near 100 per cent (impoct) & 0.80 & 7.5 & 360 & 26 & 22 \\
\hline Impact - total body lethality near 50 per cent & 0.81 & 7.3 & 340 & 25 & 22 \\
\hline Skull fracture - impact near 100 per cent & 0.85 & 6.7 & 240 & 23 & 20 \\
\hline Lung damage threshold without pressure reflection & 0.88 & 6.5 & 190 & 22 & 18 \\
\hline Serious wounds, $10 \cdot \mathrm{gm}$ gloss fragments near & & & & & \\
\hline 100 per cent & 0.88 & 6.5 & 190 & 22 & 18 \\
\hline Impact - total body letholity threshold & 0.91 & 6.0 & 150 & 20 & 17 \\
\hline Skull fracture - 10.16 stone threshold & 0.93 & 5.8 & 130 & 19 & 17 \\
\hline Cerebral concussion - 10-1b stone, mostly "safe" & 0.93 & 5.8 & 130 & 19 & 17 \\
\hline Skull fracture impact near 50 per cent & 0.96 & 5.5 & 110 & 18 & 16 \\
\hline Initial nuclear radiation injury threshold & 0.97 & 5.4 & 100 & 17 & 15 \\
\hline Eardrum failure, threshold & 1.02 & 5 & 68 & 26 & 24 \\
\hline Cerebral concussion - 10-1b stone, mostly "safe" & 1.09 & 4.5 & 42 & 14 & 12 \\
\hline Skull fracture - 10-1b stone mostly "safe" & 1.09 & 4.5 & 42 & 14 & 12 \\
\hline Skull fracture, impact threshold & 1.12 & 4.3 & 34 & 13 & 11 \\
\hline Serious wounds from $10-9 m$ glass fragments & & & & & \\
\hline near 50 per cent & 1.19 & 3.9 & 20 & 12 & 10 \\
\hline Impact - total body mostly "safe" & 1.25 & 3.6 & 13 & 11 & 9 \\
\hline Skull frocture - impoct mostly "safe" & 1.25 & 3.6 & 13 & 11 & 9 \\
\hline Eardrum failure threshold with maximum & & & & & \\
\hline pressure reflection & 1.66 & 2.3 & $<10$ & 6 & 5.2 \\
\hline Serious wounds from $10 . \mathrm{gm}$ glass fragments, threshold & 1.70 & 2.3 & $<10$ & 5.8 & 4.8 \\
\hline Second degree burns & 1.76 & 2.7 & $<10$ & 4.5 & \\
\hline & 1.92 & 1.9 & $<10$ & & 4.5 \\
\hline First degree burns & 2.29 & 1.25 & $<10$ & 2.5 & \\
\hline Skin lacerations from 10 -gm glass fragments, threshold & 2.51 & 1.25 & $<10$ & 2.0 & 2.6 \\
\hline First-degree burns & 2.56 & 1.20 & $<10$ & & 2.5 \\
\hline
\end{tabular}


TABLE 22 - RANGES INSIDE WHICH AVAILABLE DATA INDICATE THE POTENTIAL
FOR SERIOUS PRIMARY BLAST INJURY FOR THE JAPANESE
EXPLOSIONS ALONG WITH RELATED EFFECTS DATA*

\begin{tabular}{|c|c|c|c|c|c|c|c|c|}
\hline \multirow[b]{2}{*}{ EFFECTS } & \multicolumn{4}{|c|}{ HIROSHIMA } & \multicolumn{4}{|c|}{ NAGASAKI } \\
\hline & $\begin{array}{l}\text { MI-P }{ }_{1}^{\dagger} \\
\text { mile }\end{array}$ & $\begin{array}{l}\text { Related } \\
\text { effects } \\
\text { dato }\end{array}$ & $\begin{array}{l}\text { MI-P } P_{R}^{\dagger} \\
\text { mile }\end{array}$ & $\begin{array}{l}\text { Related } \\
\text { effects } \\
\text { data }\end{array}$ & $\begin{array}{l}\text { MI-P } \\
\text { mile }\end{array}$ & $\begin{array}{l}\text { Related } \\
\text { effects } \\
\text { data }\end{array}$ & ${ }_{\text {mile }}^{M I-P_{R}^{\dagger}}$ & $\begin{array}{l}\text { Related } \\
\text { effects } \\
\text { data }\end{array}$ \\
\hline \multicolumn{9}{|l|}{ Lethality } \\
\hline Near $100 \%$ & & & 0.30 & & 0.08 & & 0.48 & \\
\hline $\begin{array}{l}\text { Incident free-field overpressure, } \\
\text { psi }\end{array}$ & & & & 19 & & 58 & & 19 \\
\hline Calories per square centimeter $\ddagger$ & & & & 77 & & 190 & & 52 \\
\hline Roentgens equivalent man & & & & 13,000 & & $>105$ & & 5100 \\
\hline Near $50 \%$ & & & 0.58 & & 0.18 & & 0.56 & \\
\hline $\begin{array}{l}\text { Incident free-field overpressure, } \\
\text { psi }\end{array}$ & & & & 15 & & 42 & & 15 \\
\hline Colories per square centimeter $\ddagger$ & & & & 35 & & 150 & & 41 \\
\hline Roentgens equivalent man & & & & 1500 & & 58,000 & & 2600 \\
\hline Threshold & 0.14 & & 0.70 & & 0.34 & & 0.65 & \\
\hline $\begin{array}{l}\text { Incident free-field overpressure, } \\
\text { psi }\end{array}$ & & 30 & & 12 & & 30 & & 12 \\
\hline Calories per square centimeter & & 110 & & 39 & & 84 & & 27 \\
\hline Roentgens equivalent man & & 33,000 & & 660 & & 17,000 & & 1200 \\
\hline \multicolumn{9}{|l|}{ Lung Injury } \\
\hline Threshold & 0.58 & & 0.96 & & 0.56 & & 0.88 & \\
\hline $\begin{array}{l}\text { Incident free-field overpressure, } \\
\text { psi }\end{array}$ & & 15 & & 6.5 & & 25 & & 6.4 \\
\hline Calories per square centimeter $\ddagger$ & & 35 & & 15 & & 41 & & 18 \\
\hline Roentgens equivalent man & & 1500 & & 100 & & 2600 & & 190 \\
\hline \multicolumn{9}{|c|}{ * Blast effects assume fosterising overpressures of classical or near-classical wave forms. } \\
\hline \multicolumn{9}{|c|}{$\begin{array}{l}\dagger M 1-P_{I} \text { is the range at which incident overpressure is the challenge; } M I-P_{R} \text { is the range at which the challenge is } \\
\text { from maximal pressure reflection. }\end{array}$} \\
\hline
\end{tabular}

\section{Secondary Blast Effects - Glass Missiles}

The ranges inside which various degrees of injury might occur from 10-gm glass missiles at $10 \mathrm{ft}$ of travel are summarized in Table 23 for Hiroshima and Nagasaki, the data having been taken from Tables 20 and 21 . Only inside the ranges predicted for a very high incidence of serious wounds -0.96 mile for Hiroshima and 0.88 mile for Nagasaki - do the scaled free-field values indicate that initial nuclear radiation might produce acute illness - $100 \mathrm{rem}$ for Hiroshima and $190 \mathrm{rem}$ for Nagasaki. However at these ranges, the corresponding thermal fluxes scaled to be 15 and $18 \mathrm{cal} / \mathrm{cm}^{2}$ for Hiroshima and Nagasaki, respectively.

At the ranges predicted for the threshold of serious wounds -1.84 miles for Hiroshima and 1.70 miles for Nagasaki - the free-field thermal fluxes were near those which would produce second degree burns in both cities. At 2.7 and 2.5 miles for Hiroshima and Naga saki, respectively - 
the ranges predicted for the threshold of lacerations of the uncovered skin - the scaled corresponding thermal fluxes were below the threshold for first degree burns. Thus the available data regarding the translational velocities for window glass indicate that glass fragments vie with direct thermal radiation for being the most far-reaching hazard in both cities in Japan.

TABLE 23 - RANGES INSIDE WHICH AVAILABLE DATA INDICATE THE POTENTIAL FOR PRODUCING WOUNDS FROM SECONDARY GLASS MISSILES TRAVELING 10FT ENERGIZED BY THE JAPANESE EXPLOSIONS ALONG WITH RELATED EFFECTS DATA*

\begin{tabular}{|c|c|c|c|c|}
\hline \multirow{2}{*}{ EFFECTS } & \multicolumn{2}{|c|}{ HIROSHIMA } & \multicolumn{2}{|c|}{ NAGASAKI } \\
\hline & $\begin{array}{l}\text { Range, } \\
\text { miles }\end{array}$ & $\begin{array}{l}\text { Related } \\
\text { effects data }\end{array}$ & $\begin{array}{c}\text { Range, } \\
\text { miles }\end{array}$ & $\begin{array}{c}\text { Related } \\
\text { effects data }\end{array}$ \\
\hline \multicolumn{5}{|l|}{ Serious wounds } \\
\hline Near $100 \%$ & 0.96 & & 0.88 & \\
\hline Incident free-field & & & & \\
\hline Overpressure, psi & & 6.5 & & 6.5 \\
\hline Calories per square centimeter $\dagger$ & & 15 & & 18 \\
\hline Roentgens equivalent man & & 100 & & 190 \\
\hline Near $50 \%$ & 1.30 & & 1.19 & \\
\hline Incident free-field & & & & \\
\hline Overpressure, psi & & 3.9 & & 3.9 \\
\hline Calories per square centimeter $\dagger$ & & 8 & & 10 \\
\hline Roentgens equivalent man & & 10 & & 20 \\
\hline Threshold & 1.84 & & 1.70 & \\
\hline Incident free-field & & & & \\
\hline Overpressure, psi & & 2.3 & & 2.3 \\
\hline Calories per square centimeter $\dagger$ & & 4 & & 4.8 \\
\hline Roentgens equivalent man & & $<10$ & & $<10$ \\
\hline Skin laceration & & & & \\
\hline Threshold & 2.7 & & 2.51 & \\
\hline Incident freemfield & & & & \\
\hline Overpressure, psi & & 1.3 & & 1.3 \\
\hline Calories per square centimeter + & & 1.8 & & 2.1 \\
\hline Roentgens equivalent man & & $<10$ & & $<10$ \\
\hline
\end{tabular}

\section{Tertiary Blast Effects - Decelerative Impact}

Because trauma from decelerative impact, like that from overpressure, has the characteristic potential of producing acute lethality, it is interesting to look closely at the contents of Table 24, assembled from Tables 20 and 21. Available data indicate that inside about 0.8 mile in both Hiroshima and Nagasaki, decelerative impact following a gross bodily displacement of only $10 \mathrm{ft}$ respresents the gravest of hazards. Indeed the lethality thre shold from impact is predicted to reach as far as 1.0 mile in Hiroshima and 0.9 mile in Nagasaki, near which ranges skull fracture could occur in about 50 per cent of individuals whose heads struck solid surfaces 
during the decelerative experience. The threshold for this injury is predicted at 1.2 miles in Hiroshima and 1.1 miles in Nagasaki.

The thermal hazard extends over the entire range of potential injury from the significant translational experience, being 7 and $9 \mathrm{cal} / \mathrm{cm}^{2}$ for Hiroshima and Nagasaki, respectively, at the corresponding distances of 1.37 and 1.25 miles. At and beyond these ranges, little or no significant damage from displacement is predicted.

In contrast, the scaled figures for initial nuclear radiation indicate that significant acute injury would reach to the range inside which 50-per cent lethality from impact is predicted for Hiroshima (0.89 mile, $160 \mathrm{rem}, 17 \mathrm{cal} / \mathrm{cm}^{2}$ and $7.3 \mathrm{psi}$ ) and to the predicted impact lethality threshold for Nagasaki $\left(0.91 \mathrm{mile}, 150 \mathrm{rem} ; 17 \mathrm{cal} / \mathrm{cm}^{2}\right.$ and $\left.6.0 \mathrm{psi}\right)$.

\section{TABLE 24 - RANGES INSIDE WHICH AVAILABLE DATA INDICATE THE POTENTIAL FOR PRODUCING TERTIARY BLAST INJURY FROM IMPACT AFTER 10 FT OF TRAVEL FOR THE JAPANESE EXPLOSIONS ALONG WITH RELATED EFFECTS DATA*}

\begin{tabular}{|c|c|c|c|c|}
\hline \multirow[b]{2}{*}{ EFFECTS } & \multicolumn{2}{|c|}{ HIROSHIMA } & \multicolumn{2}{|c|}{ NAGASAKI } \\
\hline & $\begin{array}{c}\text { Range, } \\
\text { miles }\end{array}$ & $\begin{array}{l}\text { Related } \\
\text { effects } \\
\text { data }\end{array}$ & $\begin{array}{l}\text { Range, } \\
\text { miles }\end{array}$ & $\begin{array}{l}\text { Related } \\
\text { effects } \\
\text { data }\end{array}$ \\
\hline \multicolumn{5}{|l|}{ Lethality } \\
\hline $\begin{array}{l}\text { Near } 100 \% \\
\text { Incident free-field overpressure psi } \\
\text { Calories per square centimeter } t \\
\text { Roentgens equivalent man }\end{array}$ & 0.82 & $\begin{array}{c}8.2 \\
270\end{array}$ & 0.77 & $\begin{array}{r}8.2 \\
24 \\
450\end{array}$ \\
\hline $\begin{array}{l}\text { Neor } 50 \% \\
\text { Incident free-field over pressure psi } \\
\text { Calories per square centimeter } \dagger \\
\text { Roentgens equivalent man }\end{array}$ & 0.89 & $\begin{array}{l}7.3 \\
17 \\
160\end{array}$ & 0.81 & $\begin{array}{l}7.3 \\
22 \\
340\end{array}$ \\
\hline \multicolumn{5}{|l|}{ Skull fracture } \\
\hline $\begin{array}{l}\text { Near } 100 \% \\
\text { Incident free-field over pressure psi } \\
\text { Calories per square centimetert } \\
\text { Roentgens equivalent man }\end{array}$ & 0.93 & $\begin{array}{l}6.7 \\
16 \\
120\end{array}$ & 0.85 & $\begin{array}{l}6.7 \\
20 \\
240\end{array}$ \\
\hline $\begin{array}{l}\text { Lethality threshold } \\
\text { Incident free-field over pressure psi } \\
\text { Calories per square centimeter } \dagger \\
\text { Roentgens equivalent man }\end{array}$ & 1.00 & $\begin{array}{l}6.0 \\
14 \\
75\end{array}$ & 0.91 & $\begin{array}{l}6.0 \\
17 \\
150\end{array}$ \\
\hline $\begin{array}{l}\text { Near } 50 \% \\
\text { Incident free-field over pressure psi } \\
\text { Calories per square centimeter } t \\
\text { Roentgens equivalent man }\end{array}$ & 1.05 & $\begin{array}{l}5.5 \\
12 \\
54\end{array}$ & 0.96 & $\begin{array}{l}5.5 \\
110 \\
16\end{array}$ \\
\hline $\begin{array}{l}\text { Threshold } \\
\text { Incident free-field over pressure psi } \\
\text { Calories per square centimeter } t \\
\text { Roentgens equivalent man }\end{array}$ & 1.22 & $\begin{array}{l}4.3 \\
9 \\
17\end{array}$ & 1.12 & $\begin{array}{l}4.3 \\
11 \\
34\end{array}$ \\
\hline $\begin{array}{l}\text { Mostly safe } \\
\text { Incident free field over pressure psi } \\
\text { Calories per square centimeter } \dagger \\
\text { Roentgens equivalent man }\end{array}$ & 1.37 & $\begin{array}{l}3.6 \\
7 \\
<10\end{array}$ & 1.25 & $\begin{array}{l}3.6 \\
9 \\
13\end{array}$ \\
\hline
\end{tabular}

\section{IMPLICATIONS OF THE FREE-FIELD RANGE EFFECTS DATA}

\section{A. GENERAL}

The data presented above established a quantitative relationship between tentative biological criteria and the free-field effects parameters scaled for Hiroshima and Naga saki to predict the ranges inside which the potential existed for producing specified primary, secondary and tertiary blast hazards. The validity of the approach depends upon at least two matters, namely: 
1. The reliability of the scaling procedures in the physical realm.

2. The applicability of the criteria employed to man on the biological side.

There can be little doubt but that the future holds refinements in both areas and consequently revisions of both the physical and biological data lie ahead. However, an analytical beginning has been made and pursuing the approach laid out is more likely to be fruitful than not.

Whether or not the range-effects data can be applied to the experience in Hiroshima and Nagasaki depends upon a number of exigencies. Among them are:

1. The influence of the geometry and other conditions of exposure in modifying the free-field effects parameters, for it is the character and magnitude of all the environmental variations that transpire at the location of a biological target that in reality determine whether a hazard exists or not; thus the interplay between free-field and "geometric" scaling and energy exchange with animate and inanimate objects as they apply to specified exposure conditions in Japan must be thotoughly understood.

2. The ability to isolate the several blast injuries from those due to thermal and initial nuclear radiations; this may be accomplished either by having the good fortune of finding geometries of exposure in which only blast phenomena did or did not cause injury, or by knowing enough about the biological response to separate the individual biological effects in situations where two or more parameters were responsible for the injuries that occurred. In either case there is, of course, the requirement for having sample case material that is representative and not biased in any significant way.

Thus those who would employ the Japanese experience to gain more information about the biological response of man and hence refine assessment of the human hazards from blast phenomena and from nuclear and thermal radiation share common problems. Critical among them is the need to use variations in the range and conditions of exposure to obtain "dose" variations for each effect. Because one wishes to span the entire range of each hazard and because the distance covered by the several effects parameters varies, those oriented in blast and radiation biology must be interested on the average in exposures closer to ground zero than is the case for thermal biologists.

Since this is so, employment of certain shielding situations becomes mandatory. As one moves progressively from the periphery towards the hypocenter, one encounters the potential hazards defined by Tables 20 and 21 for Hiroshima and Nagasaki, respectively. For example, from Table 21, those interested in serious secondary effects from glass missiles at Nagasaki must either cope with or avoid potential burn injuries inside a range of $1.7 \mathrm{miles}\left(5-6 \mathrm{cal} / \mathrm{cm}^{2}\right.$, 2.3 psi, $<10$ rem).

Radiobiologists interested in significant radiation injury at Nagasaki will pay attention to data inside the range of about $0.97 \mathrm{mile}\left(15-17 \mathrm{cal} / \mathrm{cm}^{2}, 5.4 \mathrm{psi}, 100 \mathrm{rem}\right.$, maximum velocities above $250 \mathrm{ft} / \mathrm{sec}$ for $10-\mathrm{gm}$ glass fragments and $16 \mathrm{ft} / \mathrm{sec}$ for man). Thus one must avoid or accept very serious thermal and blast problems, the latter of a secondary and tertiary nature.

Blast biologists desiring data relevant to primary blast at Nagasaki must as sess experience inside $0.88 \mathrm{mile}\left(18-22 \mathrm{cal} / \mathrm{cm}^{2}, 190 \mathrm{rem}, 6.5 \mathrm{psi}\right)$ if pressure reflections occur, and inside $0.56 \mathrm{mile}\left(41-47 \mathrm{cal} / \mathrm{cm}^{2}, 2600 \mathrm{rem}, 15 \mathrm{psi}\right)$ if they do not. The latter is inside the range of 0.65 mile $\left(27-37 \mathrm{cal} / \mathrm{cm}^{2}, 1200 \mathrm{rem} 12 \mathrm{psi}\right)$ marking the estimated threshold for potential lethality with maximal pressure reflections. Without the latter, lethality is estimated as a possibility inside the ranges of $0.18-0.34 \mathrm{mile}\left(84-162 \mathrm{cal} / \mathrm{cm}^{2}, 17,000\right.$ to $58,000 \mathrm{rem}$, $30-42$ psi). 
Since over-all lethality was around 80 per cent at 0.5 mile and 50 percent at 0.8 mile at Nagasaki, 26, 65-67 it is obvious that case material of use in assessing primary blast effects will be minimal. Added to this is the bias introduced by the early lethality characterizing injury from overpressures, from impact and from other causes. Thus blast biologists face great difficulties with regard to the use of the Japanese data.

In any case, all personnel interested in the Japanese experience must solve the problems concerning free-field and "geometric" scaling, the conditions of exposure as these influence secondary and tertiary events, bias in the data when it exists and no doubt biologic response to combined injury.

\section{B. SPECIFIC}

A few specific matters relevant to some of the complexities mentioned above will now be discussed.

\section{The 20-Day-Survivor Sample}

Those who have carefully studied the evidence of various injuries that occurred in Hiroshima and Nagasaki recognized the need for careful interpretation of the data collected from survivors. For example, the left portions of the curves shown in Figures 36 and 37, reproduced from Oughterson and Warren ${ }^{26}$ and referable to variation in per cent burns as a function of range, do not reflect the incidence of burns among all exposed individuals. As Oughterson and Warren pointed out, "the low percentage of burns in the innermost zones must be discounted owing to the fact that the most severely injured died at once or within a few days." However, the curves show the remarkable minimization of thermal bums associated with exposure under shielded conditions.

The dotted curves to the left in Figures 38 and 39 indicate appreciation by the above authors of the high incidence of thermal and blast effects in the inner zones which the data obtained from survivors could not be expected to reveal since most of the close-in casualties died quickly and therefore either did not reach medical channels at all or did so in limited numbers. Obviously, only those well enough protected to be able to move out of the cities under their own power or with minimal help were recorded among the survivors.

Also, it is important to realize that the term "blast injuries" in many of the publications on effects in Japan is limited only to the indirect variety, * meaning mostly mechanical injuries due to secondary debris. The significance of direct blast injuries and those due to impact was simply not appreciated, no doubt because the characteristic very early le thality precluded such cases reaching medical channels. Too, such injuries, perhaps more often than not, were complicated by burns and acute radiation sickness which added to the casualties listed as "immediate" or those who "died at once" and therefore introduced a "selective" factor that must be recognized in the sample of survivors available for study. However, "fixing", the cause of lethality, if at all possible in a representative sample of cases, is important because the relative significance of blast and thermal effects increases progressively with explosive yield.

\footnotetext{
* See section $3.4(\mathrm{~d})(1)$ bottom of page 37 in the text of Oughterson and
}

Warren. 26 


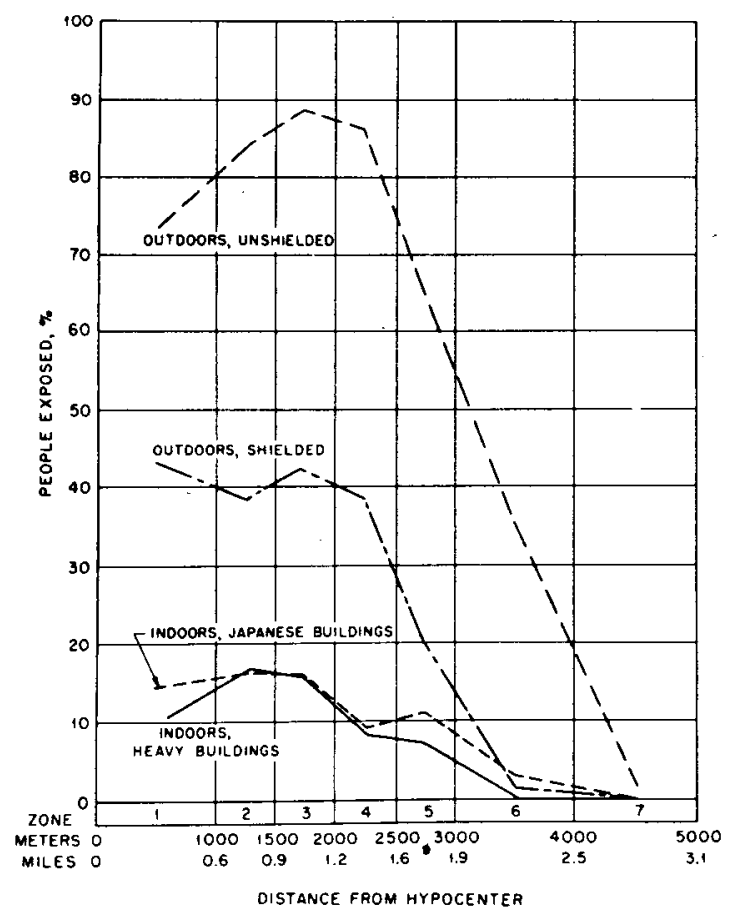

Figure 36

Incidence of burns by distance and shielding at Hiroshima.

(Figure 3.22 from Oughterson and Warren.26)

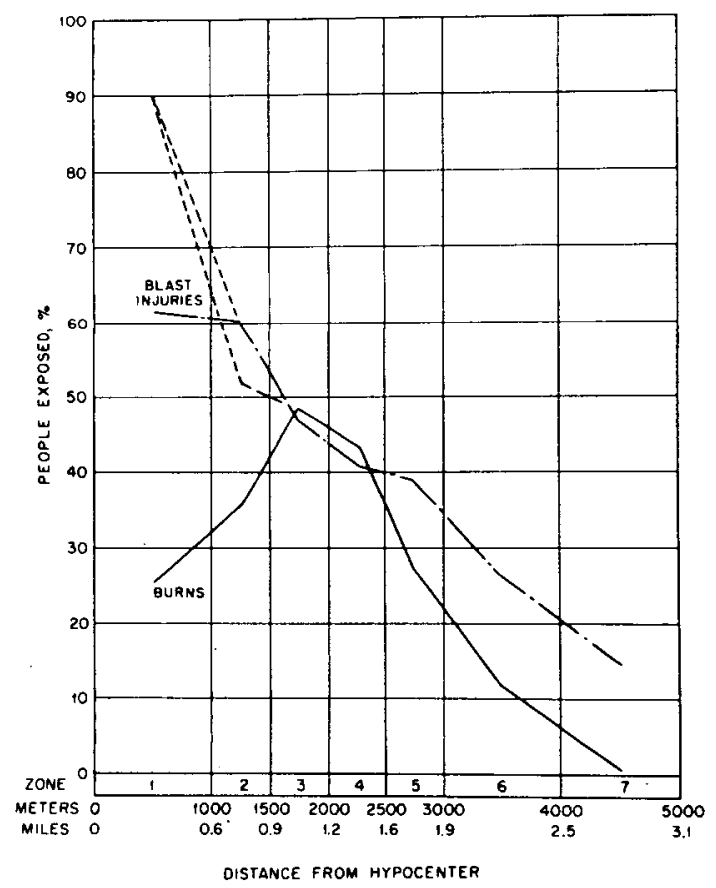

Figure 38

Incidence of blast injuries and burns by distance at Hiroshima. ---, probable incidence in the innermost zones, assuming that all those killed were injured by blast and radiant heat.

(Figure 3.20 from Oughterson and Warren.26)

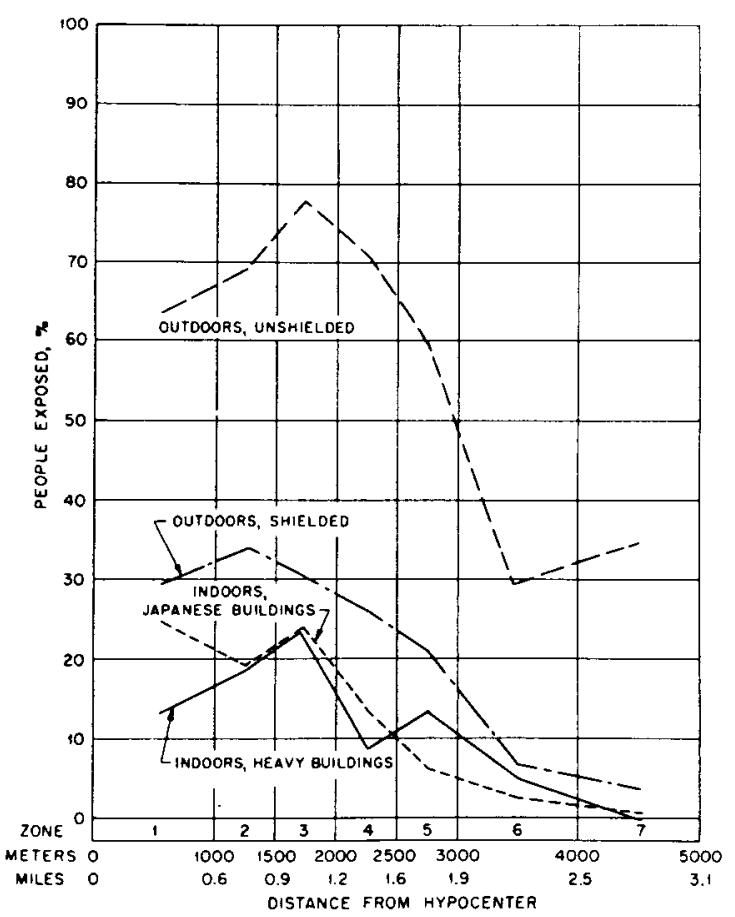

Figure 37

Incidence of burns by distance and shielding at Nagasaki.

(Figure 3.23 from Oughterson and Warren.26)

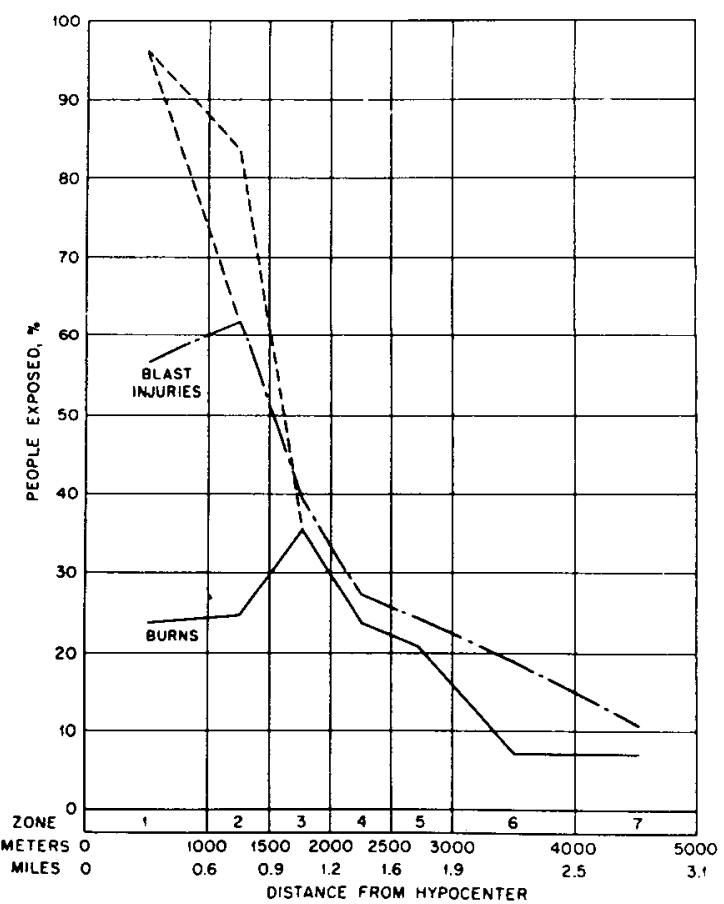

Figure 39

Incidence of blast injuries and burns by distance, Nagasaki. ---, probable incidence in the innermost zones, assuming that all those killed were injured by blast and radiant heat.

(Figure 3.21 from Oughters on and Warren.26) 


\section{The Bankers' Club}

As a case in point, it is both instructive and interesting to note data conceming the Bankers' Club (located 0.155 mile - 250 meters - from the Hiroshima hypocenter) pieced together from published data 25,66,67 and information existing in the records of the Armed Forces Institute of Pathology. ${ }^{8}$ The figures, assembled in Tables 25 and 26 - which also give the scaled freefield effects parameters - show there were 48 individuals said to be exposed inside the threestory building. There were 25 persons reported as suffering instant death and 23 survivors, 21 of whom died at the indicated times up to 18 days. The locations of seven survivors were noted; five exposed on the first and second floors died; two exposed on the first floor lived.

Figure 40, graphically portraying the lethality-time curves for those fatally injured in the Bankers' Club, shows the early and delayed lethality for all ca ses. Too, the delayed lethality is further segregated between individuals who did and did not receive what was judged to be significant bums.

Figure 41 includes the over-all lethality-time curve compared wi th that for delayed lethality when the latter is expressed as a per cent of total cases in the delayed category. Figure 42 similarly shows delayed lethality curves when cases are divided among those with bums who tended to succumb earlier (left curve) and those without bums (right curve).

TABLE 25 - EARLY AND DELAYED LETHALITY FOR BANKERS' CLUB 250 METE RS (0.155 MILE) FROM HIROSHIMA HYPOCENTER *

\begin{tabular}{|c|c|c|c|c|c|c|c|c|c|c|}
\hline \multirow{3}{*}{$\begin{array}{c}\text { POST-SHOT } \\
\text { DAY }\end{array}$} & \multicolumn{10}{|c|}{ LETHAL CASES } \\
\hline & \multicolumn{4}{|c|}{ WITH BURNS ACCUM. } & \multicolumn{3}{|c|}{ WITHOUT BURNS ACCUM. } & \multicolumn{3}{|c|}{ TOTALS ACCUM. } \\
\hline & No. & No. & No. & $\begin{array}{l}\text { PER } \\
\text { CENT }\end{array}$ & No. & No. & $\begin{array}{l}\text { PER } \\
\text { CENT }\end{array}$ & No. & No. & $\begin{array}{l}\text { PER } \\
\text { CEN T }\end{array}$ \\
\hline 0 & $25+$ & & 25 & 54.3 & & 25 & 54.3 & 25 & 25 & 54.3 \\
\hline 6 & & 2 & 27 & 58.7 & & & & 2 & 27 & 58.7 \\
\hline 7 & & 2 & 29 & 63.0 & 1 & 26 & 56.5 & 3 & 30 & 65.2 \\
\hline 8 & & 1 & 30 & 65.2 & 1 & 27 & 58.7 & 2 & 32 & 69.6 \\
\hline 9 & & 5 & 35 & 76.1 & 1 & 28 & 60.9 & 6 & 38 & 82.6 \\
\hline 10 & & 2 & 37 & 80.4 & 2 & 30 & 65.2 & 4 & 42 & 91.3 \\
\hline 12 & & & & & 1 & 31 & 67.4 & 1 & 43 & 93.5 \\
\hline 14 & & & & & 1 & 32 & 69.2 & 1 & 44 & 95.7 \\
\hline 18 & & 1 & 38 & 82.6 & 1 & 33 & 71.7 & 2 & 46 & 100 \\
\hline TOTAL & 25 & 13 & & & 8 & & & 46 & & 95.8 \\
\hline SURVIVORS & & $i$ & & & 1 & & & 2 & & 4.2 \\
\hline TOTAL & 25 & 14 & 39 & 81.3 & 9 & 34 & 70.8 & 48 & 48 & 100 \\
\hline
\end{tabular}

* REFERENCES: NP.3037, VOL. II, P. $110 ; 67$ OUGHTERSON AND WARREN, P. 58; ${ }^{26}$ AFIP RECORDS. $68+$

+ IMMEDIATE LETHALITY ( 8,9 and 8 Cases on first, second and third floors, respectively.)

Free-field effects data for 20 KT: HOB 1988 FT (606 Meters)

(REF. ENW-1962.)

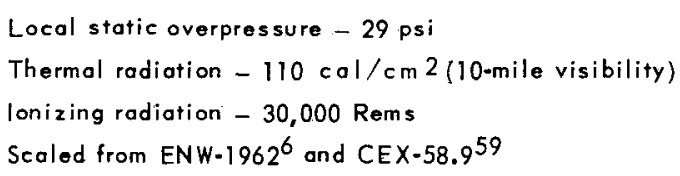


TABLE 26 - OVERALL (EARLY PLUS DELAYED) AND DELAYED LETHALITY FOR BANKERS' CLUB 250 METERS (0.155 MILE) FROM HIROSHIMA HYPOCENTER *

\begin{tabular}{|c|c|c|c|c|c|c|c|c|c|}
\hline \multirow{3}{*}{$\begin{array}{c}\text { POST-SHOT } \\
\text { DAY }\end{array}$} & \multicolumn{9}{|c|}{ LETHAL CASES } \\
\hline & \multicolumn{3}{|c|}{ WITH BURNS ACCUM. } & \multicolumn{3}{|c|}{ WITHOUT BURNS ACCUM. } & \multicolumn{3}{|c|}{ TOTALS ACCUM. } \\
\hline & No. & No. & $\begin{array}{r}\text { PER } \\
\text { CENT } \\
\end{array}$ & No. & No. & $\begin{array}{r}\text { PER } \\
\text { CEN T } \\
\end{array}$ & NO. & No. & $\begin{array}{c}\text { PER } \\
\text { CENT } \\
\end{array}$ \\
\hline 0 & & & & & & & 25 & 25 & 54.3 \\
\hline 6 & 2 & 2 & 15.4 & & & & 2 & 27 & 58.7 \\
\hline 7 & 2 & 4 & 30.8 & 1 & 1 & 12.5 & 3 & 30 & 65.2 \\
\hline 8 & 1 & 5 & 38.5 & 1 & 2 & 25.0 & 2 & 32 & 69.6 \\
\hline 9 & 5 & 10 & 76.9 & 1 & 3 & 37.5 & 6 & 38 & 82.6 \\
\hline 10 & 2 & 12 & 92.3 & 2 & 5 & 62.5 & 4 & 42 & 91.3 \\
\hline 12 & & & & 1 & 6 & 75.0 & 1 & 43 & 93.5 \\
\hline 14 & & & & 1 & 7 & 87.5 & 1 & 44 & 95.7 \\
\hline 18 & 1 & 13 & 100 & 1 & 8 & 100 & 2 & 46 & 100 \\
\hline TOTALS & 13 & & & 8 & & & 46 & & \\
\hline
\end{tabular}

Now the interpretation of the mortality-time curves referable to the Bankers' Club is not simple and requires a great deal of information not now available to the authors. However, a lethality-time curve, second from the right in Figure 43, was constructed from the data in Table $27^{67}$ referable to the reported exposure of 51 individuals in the open at 0.477 mile $(750$ meters) from the Hiroshima hypocenter (16.1 psi, $\left.48 \mathrm{cal} / \mathrm{cm}^{2}, 3800 \mathrm{rem}\right)$. Thus, the challenge from thermal and nuclear radiations was well above what appears to be the lethal range while the primary blast hazard was at about the threshold for lung injury. In spite of this, the exposed individuals exhibited a rising-lethality curve (see Figure 43) that reached 100 per cent in seven days. It would be nice to know that this curve, the scaled free-field effects parameters and the reported exposure condition were all accurate; for if so, such data would help in terpret what occurred in the Bankers' Club. Similar remarks apply to exposures at Hiroshima of a number of individuals in the open at 1000 meters $\left(0.62 \mathrm{mile}, 14.5 \mathrm{psi}, 1200 \mathrm{rem}, 32 \mathrm{cal} / \mathrm{cm}^{2}\right.$, displacement velocity $58 \mathrm{ft} / \mathrm{sec}$ in $10 \mathrm{ft}$ for "average" man), the lethality-time curve for which is given on the right in Figure 43. Apparently the levels of ionizing and thermal radiation that were incident at 750 and 1000 meters did not produce immediate death but rather a delayed lethality over a period of one to two or three weeks.

Because the experience at the Bankers' Club indicated an early component of lethality that accounted for 25 (54 per cent) deaths occurring instantly (plotted as within the first day), attention is called to the two curves at the left of Figure 43. The steepest curve, rising to 100 per cent in 24 hours applies to guinea pigs lethally injured by impact. ${ }^{3} 3$

(See Figure 24.) The curve immediately to the right was taken from Figure 17 and refers to guinea pigs lethally injured by "fast"-rising "long"-duration overpressures. 47 These two curves illustrate very well indeed the early lethality that characteristically occurs in mammals subjected to violent impact and hazardous overpressures when the animals are untreated after experimental injury. It makes only common sense to suggest that tertiary effects without question and perhaps primary blast damage contributed to the early and probably to the delayed component of lethality noted in individuals exposed in side the Bankers' Club. Certainly the potential for very high translational velocities in the case of man existed and the overpressures of 29 psi were well above the 15-psi threshold for lung injury and approach the lower range of lethality estimated for man ( $30 \mathrm{psi}$ ). 


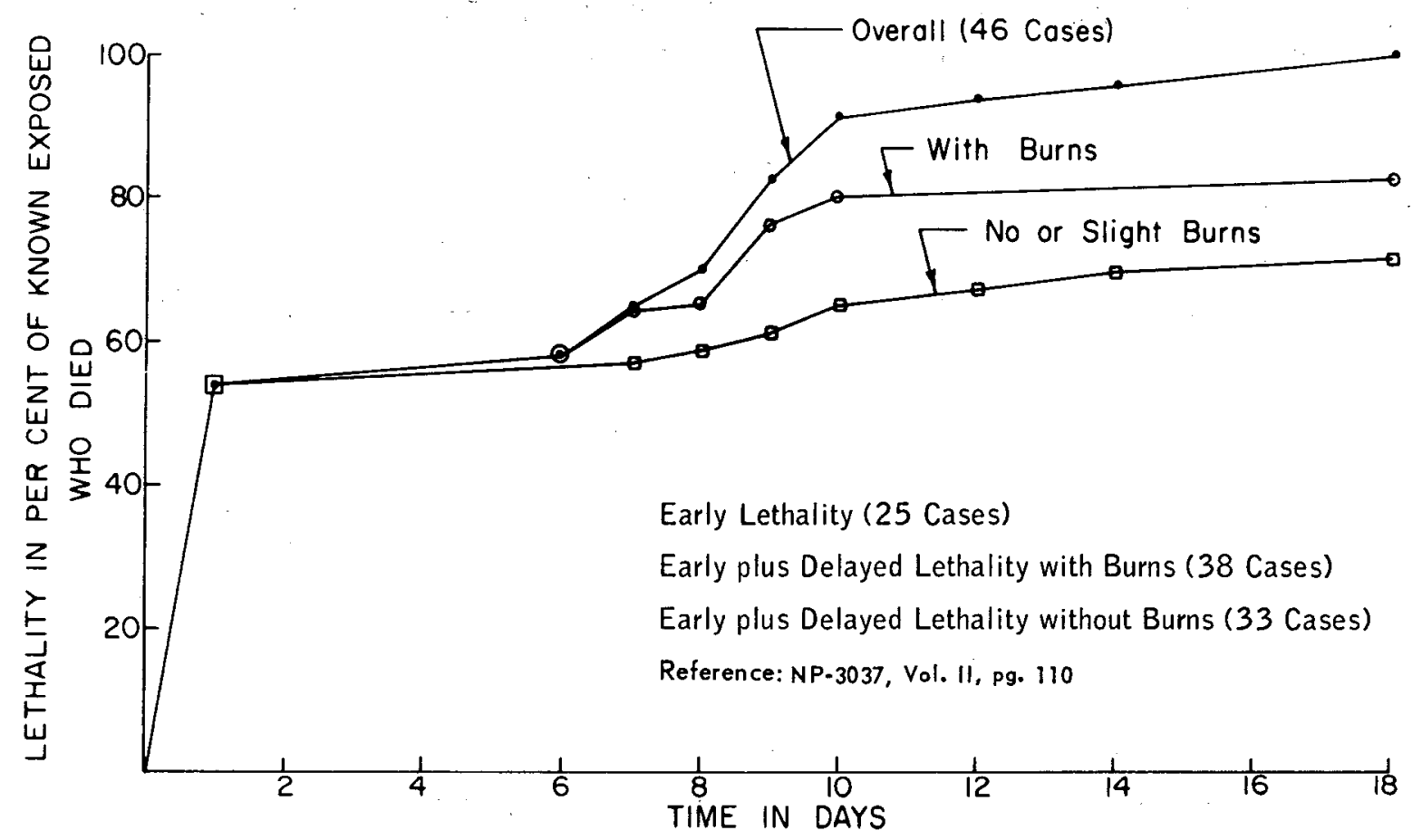

Figure 40 - Early and delayed lethality for Bankers' Club (250 meters) at Hiroshima.

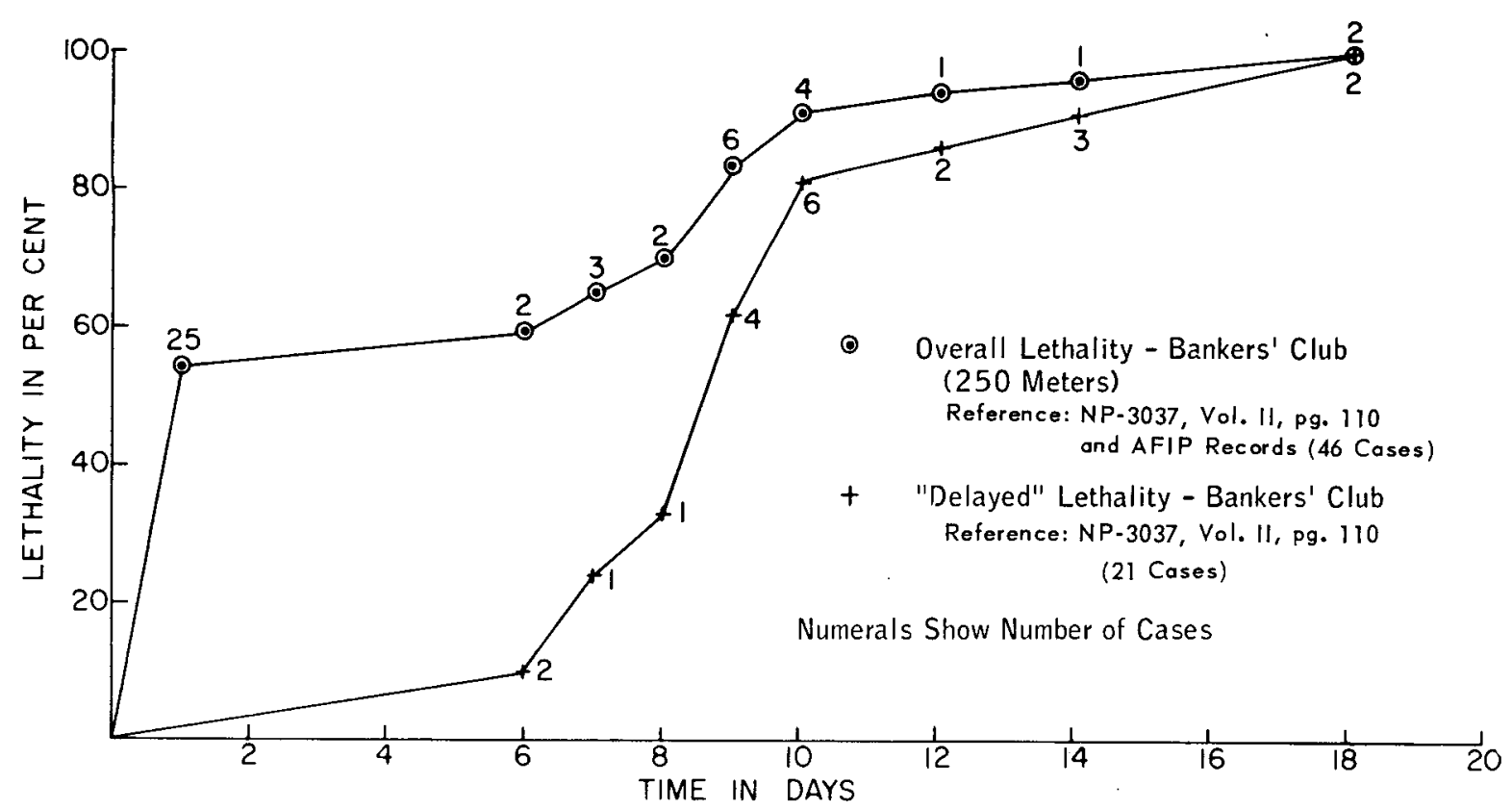

Figure 41 - Overall (early plus delayed) and delayed lethality for Bankers Club (250 meters) at Hiroshima. 


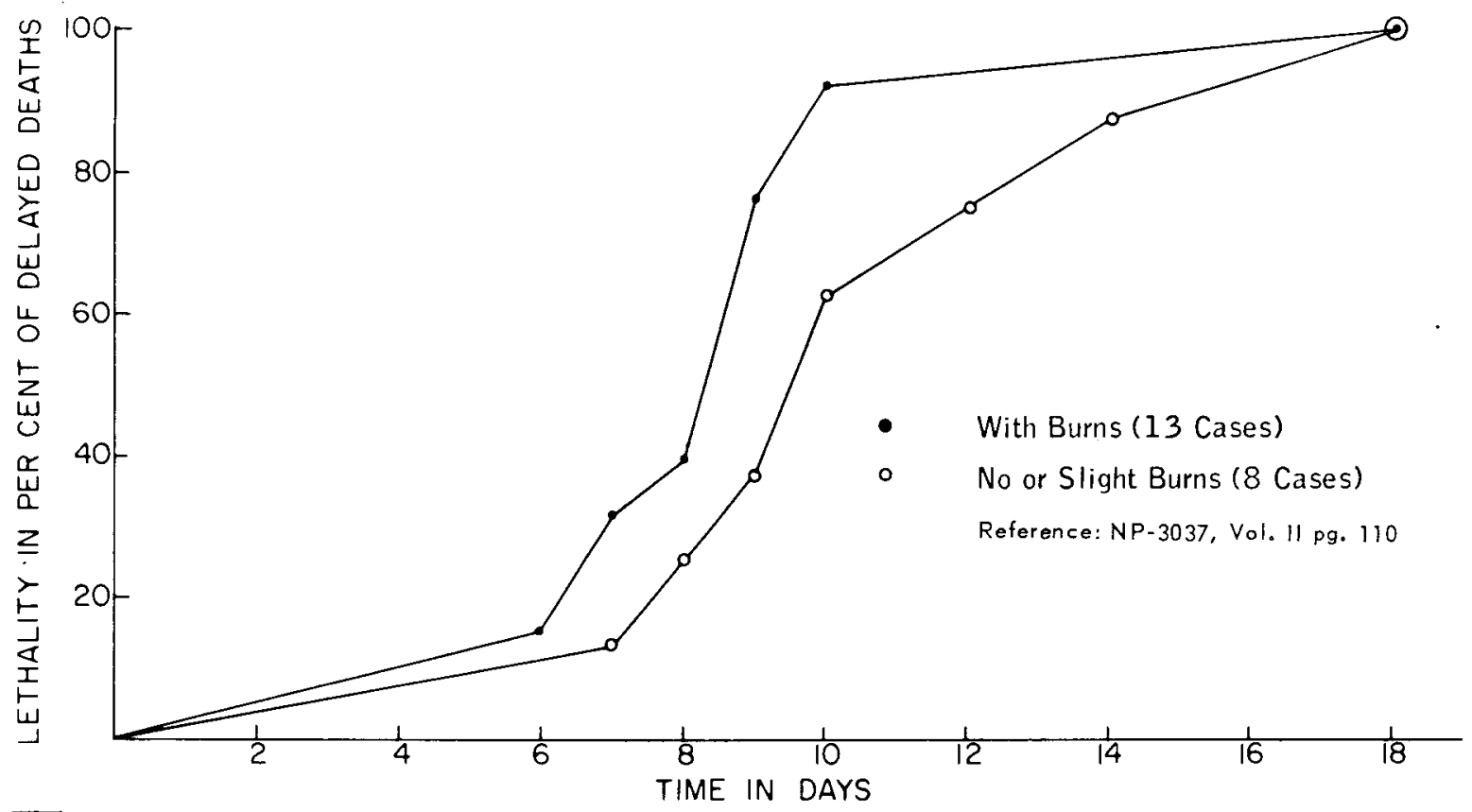

Figure 42 - Delayed lethality for Bankers' Club (250 meters) at Hiroshima.

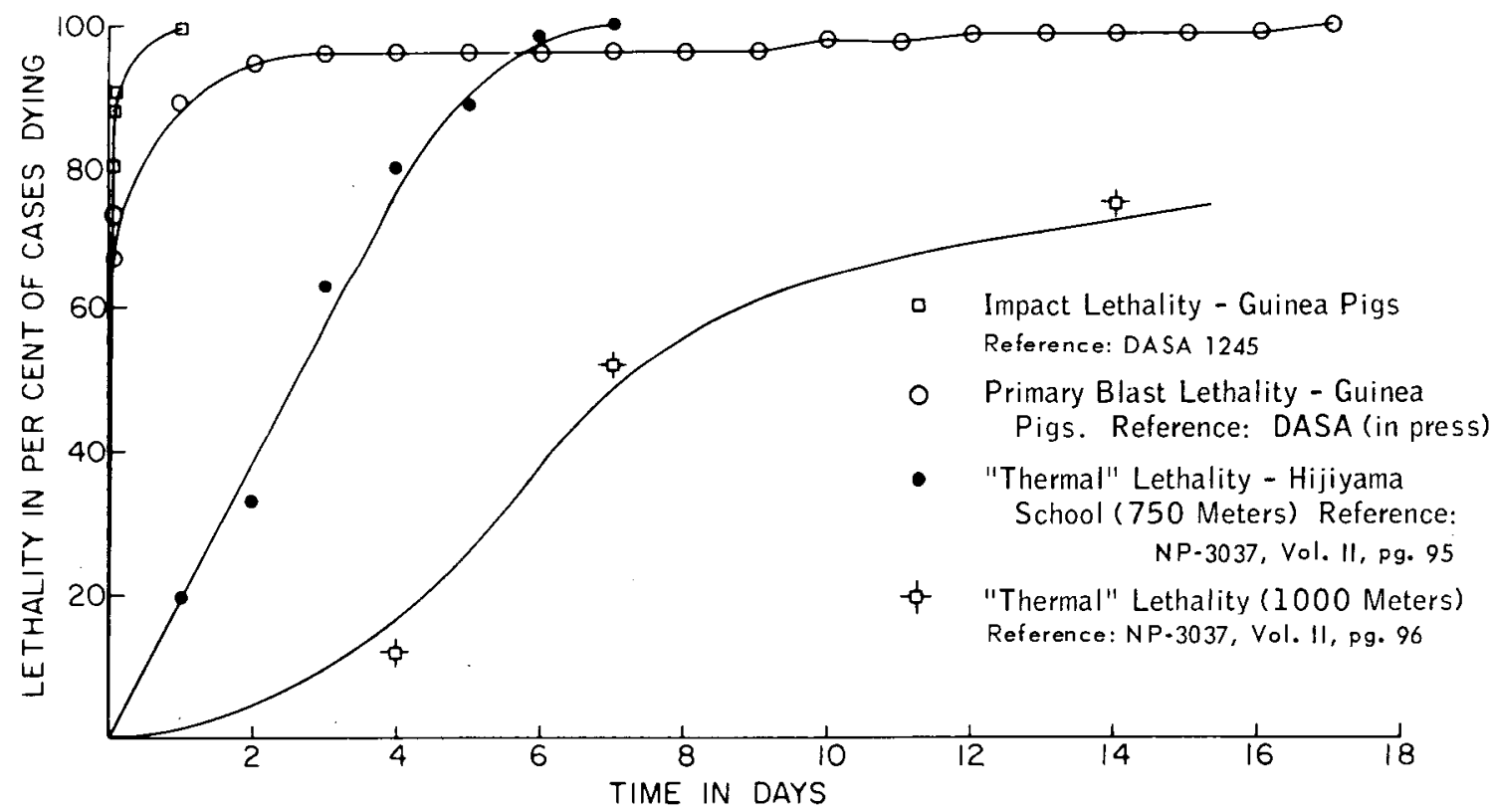

Figure 43 -Typical lethality-time curves. 
TABLE 27 - LETHALITY -TIME DATA FOR HIJIYAMA SCHOOL 750 METERS

(0.466 MILE) FROM HIROSHIMA HYPOCEN TER

(Ref. NP-3037, Vol. II, Page 9567)

Free-Field Effects Data for 20.kt Yield: Height of Burst, $1988 \mathrm{ft}$.

Local Static Overpressure, $16.1 \mathrm{psi}$

Thermal Radiation, $48 \mathrm{cal} / \mathrm{cm}^{2}$

( $10-m i l e$ visibility)

lonixing Radiation, 3800 rem

LETHAL CASES

\begin{tabular}{|c|c|c|c|c|}
\hline \multirow{2}{*}{ POSTSHOT DAY } & \multirow{2}{*}{ NO. OF CASES } & PERCENT & NO. OF CASES & PC CUMULATED \\
\cline { 3 - 5 } & & & 10 & 19.6 \\
\hline 1 & 10 & 19.61 & 17 & 33.3 \\
3 & 7 & 13.73 & 32 & 62.7 \\
4 & 15 & 29.41 & 41 & 80.4 \\
5 & 9 & 17.65 & 45 & 98.0 \\
6 & 4 & 7.84 & 50 & 100 \\
7 & 5 & 9.80 & 51 & \\
\hline
\end{tabular}

However, the latter applied only to classical or near-classical wave forms, and it is not possible now to say what was the shape of the pressure-time pulse inside the various portions of the Bankers' Club.

Attention is called to the lower two curves of Figure 18 which show that even when overpressures of exposure are relatively low, but within the lethal range, there is an immediate and delayed component of lethality. Also the latter, depending on the magnitude of the "fast"rising pressure, may be delayed as long as two or three days or extend up to 10 to 20 days after exposure.

\section{Chinzei Scbool (Nagasaki) 26}

Though data with which to construct lethality-time curves are not currently at hand, figures applicable to the exposure of 118 individuals inside the Chinzei School located just outside the estimated range of mach-stem formation ( 0.26 mile) at 500 meters ( 0.31 mile) from the Nagasaki hypocenter are highly interesting $\left(P_{I}=32 \mathrm{psi}, P_{R}=110 \mathrm{psi}, 95 \mathrm{cal} / \mathrm{cm}^{2}, 22,000 \mathrm{rem}\right)$.

As shown in Table 28, there were 27 individuals and no survivors in the wooden portion of the school. Delayed and instant lethality were cited as 18.5 and 81.5 per cent, respectively. Inside the four-story concrete portion of the school, 91 persons were exposed; 15 (12.7 per cent) survived while 46 (50.5 per cent) and 30 (33.0 per cent) suffered in stant and delayed lethality, respectively.

Events which transpired at the Chinzei School, and at all-other heavy buildings in Japan for that matter, deserve further close atten tion. For example and first, if an initial effort indicated that the biological data and those referable to the geometry of exposure were good enough to justify follow-on activities, then secondly, the considerable and precise effort it would take to determine the environmental variations that existed immediately inside the several portions of the structures should be undertaken. 
TABLE 28 - SURVIVAL AND LETHALITY DATA FOR CHINZEI SCHOOL 500 METERS (0.31 MI) FROM NAGASAKI HYPOCENTER *

*REFERENCE: OUGHTERSON AND WARREN, PG. 66, 26

Freefield Effects Doto for $20 \cdot k+$ Yield:

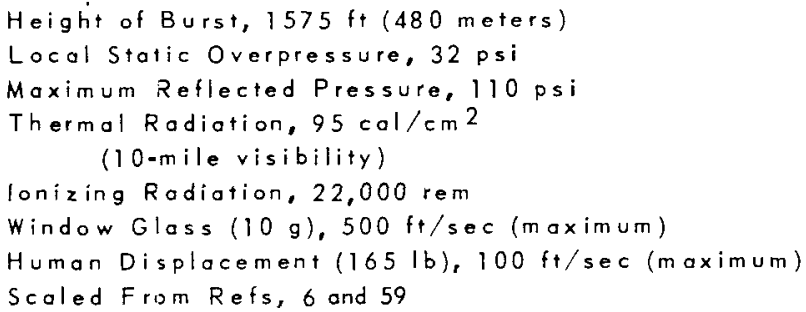

\begin{tabular}{|c|c|c|c|c|c|c|c|c|}
\hline \multirow[b]{2}{*}{ LOCATION } & \multicolumn{2}{|c|}{$\begin{array}{l}\text { IMMEDIATE } \\
\text { LETHALITY }\end{array}$} & \multicolumn{2}{|c|}{$\begin{array}{l}\text { DELAYED } \\
\text { LETHALITY }\end{array}$} & \multicolumn{2}{|c|}{ SURVIVAL } & \multicolumn{2}{|c|}{ TOTAL } \\
\hline & No. & $\begin{array}{l}\text { PER- } \\
\text { CENT }\end{array}$ & NO. & $\begin{array}{l}\text { PER- } \\
\text { CENT }\end{array}$ & No. & $\begin{array}{l}\text { PER- } \\
\text { CENT }\end{array}$ & No. & $\begin{array}{l}\text { PER- } \\
\text { CENT }\end{array}$ \\
\hline $\begin{array}{l}\text { Wooden } \\
\text { Portion }\end{array}$ & 22 & 81.5 & 5 & 18.5 & 0 & 0 & 27 & 100 \\
\hline $\begin{array}{l}\text { Concrete } \\
\text { Portion }\end{array}$ & 46 & 50.5 & $30 *$ & 33.0 & $15+$ & 16.5 & 91 & 100 \\
\hline Totals & 68 & 57.6 & 35 & 29.7 & 15 & 12.7 & 118 & 100 \\
\hline
\end{tabular}

\section{The "Equivalence" Concept}

Thirdly, all possible avenues to improve "fixing" the free-field parameters that apply to the close-in structures is not only fundamental to the studies of effects-time phenomena that occurred inside the buildings, but there is a good possibility of developing "equivalence" concepts that might aid the extrapolation of the $20-\mathrm{kt}$ effects data in Japan to situations of higher explosive yield. For example, the association of $32 \mathrm{psi}$ with $22,000 \mathrm{rem}$ * at the Chinzei School can be applied to the overpressure-initial nuclear radiation-yield chart shown in Figure 27 . The point defined by the 32 psi-22,000 rem relationship lies at about $200 \mathrm{kt}$. Were the value of the initial nuclear radiation as low as $6000 \mathrm{r}$ given by Oughterson and Warren ${ }^{26}$ then the 32 psi-6000 r point lies a little below 1-MT yield.

Thus with the figures at hand, it may be stated that the environmental level of overpressure and initial nuclear radiation existing at the location of the Chinzei School is "equivalent" to that produced by a nuclear explosion with a yield between $200 \mathrm{kt}$ and IMT if the detonation occurred at the earth's surface near sea level.

Though this "equivalence" is valid pressure-rem wise, it is not pressure-thermal wise. Use of a chart similar to that in Figure 27 but applicable to the pressure-cal/ $\mathrm{cm}^{2}$-yield interrelationship (or scaling the value after Glasstone ${ }^{6}$ or Fletcher, et al. ${ }^{63}$ ) reveals that about $580 \mathrm{cal} / \mathrm{cm}^{2}$ is associated with an overpressure of $32 \mathrm{psi}$ from a sea-level burst of $1 \mathrm{MT}$, a figure well above the $95 \mathrm{cal} / \mathrm{cm}^{2}$ scaled for the Chinzei School. Two things may be said about this matter as follows:

* The authors are well aware of the uncertainties concerning the 22,000 rem figure scaled for free-field conditions by following Glasstone's The Effects of Nuclear Weapons, ${ }^{5}$ which gives data applicable to nuclear explosions in general and figures so estimated may or may not apply to any given detonation including the one at Vagasaki. The 22,000 rem value is neither consistent with the York curves cited by Ritchie and llurst ${ }^{12}$ nor with the figure cited for the Chinzei School in the text of Oughterson and Warren. ${ }^{26}$ Also, see the Discussion. 
(1) Such thinking makes it important to separate the biological effects in Japan between those due to blast, thermal and initial nuclear radiation and to pursue studies on the effects of combined injury as will be discussed later.

(2) The free-field thermal flux of $580 \mathrm{cal} / \mathrm{cm}^{2}$ is not far from that existing outside an underground shelter tested with open entryways at the Nevada Test Site in $1955 .{ }^{8}$ Animals inside were singed and one was severely burned. The effect was not due to scatter of the thermal radiation 28,29 in the entryway, but to hot dust-laden gases which came inside during the fill phase of the structure; i.e., about $90 \mathrm{msec}$, the time to maximum pressure.

The argument will not be pursued farther here. There can be little doubt, however, that further development of what has been termed the "equivalence" concept above offers an approach of considerable utility, first in applying selected Japanese data to the problem of scaling biological effects to higher explosive yield, and second in guiding rel evant experimentation that must be undertaken to understand better the effects of the nuclear-yield spectrum available today. For example, the range-yield-thermal effects relationship given in Figure 26, combined with what has been said above and experience in shelters in Nevada, makes it evident that a great deal more needs be learned about the biological and physical effects of hot gases.

\section{The Hot-Gas Problem}

On the physical side, Vortman ${ }^{9}$ in 1955 reported temperature-time curves recorded inside the underground structure in which animals exposed for blast studies were burned. ${ }^{8} \mathrm{~A}$ maximum temperature peak of $250^{\circ} \mathrm{C}, 40 \mathrm{msec}$ after arrival of the shock front was documented. Greig and Pearse 28 in 1957 reported severe burns in pigs in the same shelter used in 1955, but temperature-time data were not obtained; also, the authors said nothing definitive about the cause of the burns. In 1945, Ashe and Roberts ${ }^{6}$ exposed human volunteers to air heated to different temperatures and blown at six liters per minute through a tube one $\mathrm{cm}$ in diameter onto the skin for various periods of time. Figure 44 shows the data.

Air of $250^{\circ} \mathrm{C}$, the maximal transient temperature recorded by Vortman in the Nevada shelter, required over a second to produce even a first degree burn as can be seen from Figure 44 . However, the velocity of the dust-laden air in the underground shelter at the location where thermal lesions were produced was very high indeed and of course well above that used by Ashe and Roberts. 69

Obviously, a great deal more work needs be done in this area. Since this statement represents the point of the discussion, the matter will be dropped here with the observation that this is an important area deserving - and requiring - the attention of well qualified personnel.

\section{Combined Injury}

Among the immediate and eventual survivors of exposure at the Chinzei School, burns and wounds, radiation injury, other injury and death with unknown cause were reported as noted at the bottom of Table 28. These findings, along with similar information for the Bankers' Club and other heavy buildings that were not leveled by the blast, highlight the need for knowing a great deal about the biological response to combined injury if hazards assessment for nuclear explosions is to be even reasonably well understood. 


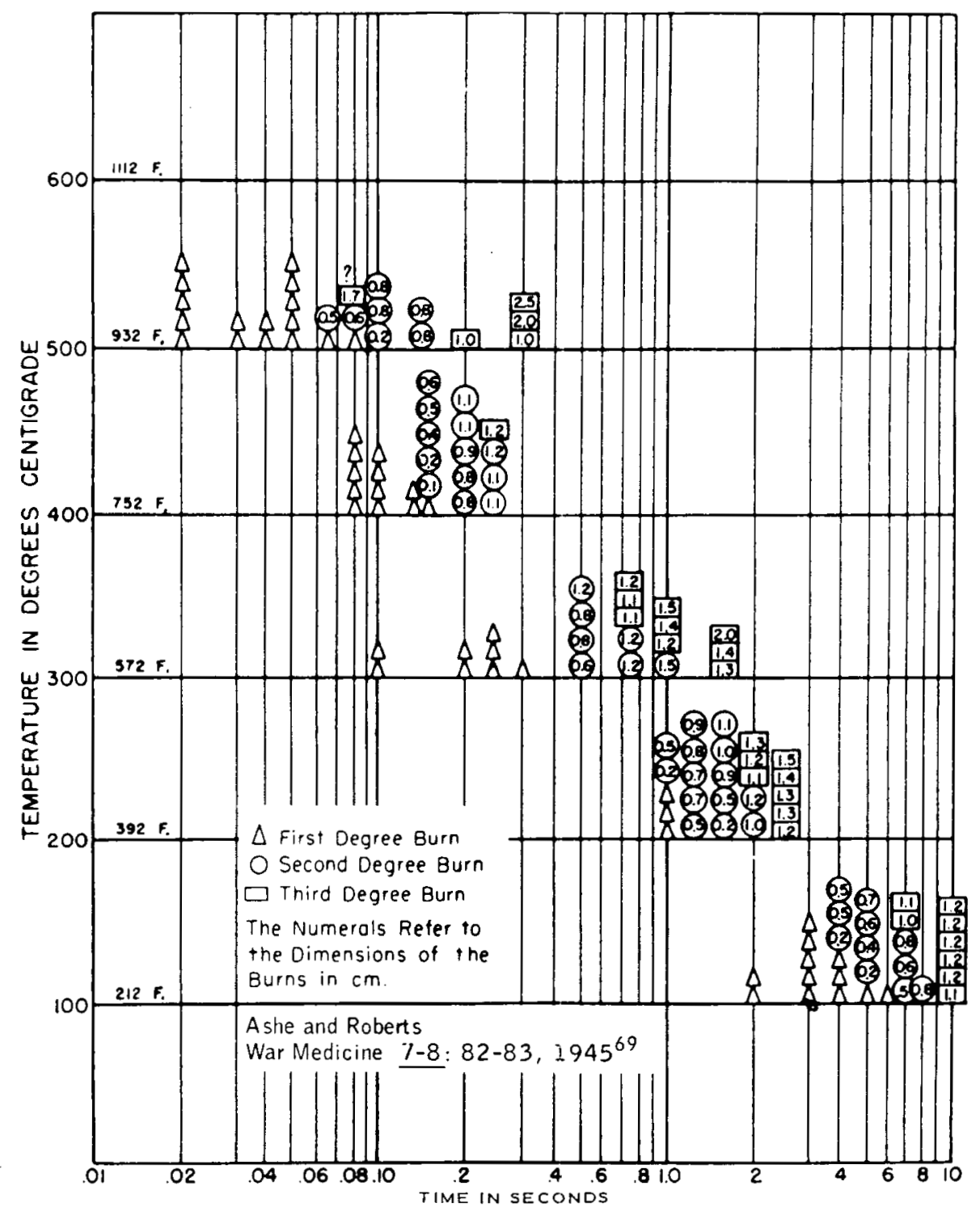

Figure 44 - Temperature-time relationship producing indicated degree of hot-air burns of human skin.

This statement can be reinforced by noting a few of the over-all figures from available studies of the Japanese experience. For example, Table 29 from Oughterson and Warren ${ }^{25}$ gives the breakdown of the 20-day-survivor data for Hiroshima and Nagasaki to show the number and percentage of individuals injured only by blast, * heat and ionizing radiation or by various combinations of the three. In Table 30 from the same authors, 26 the number of injuries is noted among survivors segregated to give information on the combinations of the several types observed.

Table 31 summarizes the previous two rables to emphasize the significance of multiple injuries. Tabulated in the upper portion of Table 31 are figures showing that among 72,000 20-day survivors in Hiroshima, 43,533 exhibited single-type injuries while 28,467 were multiple in character. For Nagasaki, there were 14,420 and 10,580 cases with single and multiple injuries, respectively. Thus, about 60 per cent of the total for the two cities had single while near 40 per cent exhibited multiple injuries.

* Vote that "blast" as used by Oughterson and Warren 26 refers only to indirect injuries. 
TABLE 31 (PART I) - TOTALS FOR MULTIPLE INJURY DATA TAKEN FROM TABLES 29 AND 30 AFTER OUGHTERSON AND WARREN 26 SUMMARY NUMBER OF INDIVIDUALS AMONG TWENTY-DAY-SURVIVORS AT HIROSHIMA AND NAGASAKI EXHIBITING SINGLE AND MULTIPLE INJURIES

\begin{tabular}{|c|c|c|c|c|c|c|}
\hline \multirow{2}{*}{ INJURY } & \multicolumn{2}{|c|}{ HIROSHIMA } & \multicolumn{2}{|c|}{ NAGASAKI } & \multicolumn{2}{|c|}{ TOTALS } \\
\hline & Single & Multiple & Single & Multiple & Single & Multiple \\
\hline $\begin{array}{l}\text { One type } \\
\text { Two types } \\
\text { Three types }\end{array}$ & 43,533 & $\begin{array}{r}24,857 \\
3,610 \\
\end{array}$ & 14,420 & $\begin{array}{l}9.283 \\
1.297\end{array}$ & 57,953 & $\begin{array}{r}34,140 \\
4,907\end{array}$ \\
\hline TOTAL & 43,533 & 28,467 & 14,420 & 10,580 & 57,953 & 39,047 \\
\hline TOTAL & & & & & & \\
\hline PER CENT & 60.5 & 39.5 & 57.7 & 42.3 & 59.7 & 40.3 \\
\hline
\end{tabular}

TABLE 31 (PART II) - TOTALS FOR MULTIPLE INJURY DATA TAKEN FROM TABLES 29 AND 30 AFTER OUGHTERSON AND WARREN 26 SUMMARY NUMBER OF SINGLE AND MULTIPLE TYPE INJURIES AMONG TWENTY-DAY-SURVIVORS IN HIROSHIMA

\begin{tabular}{|c|c|c|c|c|c|c|}
\hline \multirow{2}{*}{ INJURY } & \multicolumn{2}{|c|}{ HIROSHIMA } & \multicolumn{2}{|c|}{ NAGASAKI } & \multicolumn{2}{|c|}{ TOTALS } \\
\hline & Single & Multiple & Single & Multiple & Single & Multiple \\
\hline $\begin{array}{l}\text { One type } \\
\text { Two types } \\
\text { Three iypes }\end{array}$ & 43,533 & $\begin{array}{l}49,714 \\
10,830\end{array}$ & 14,420 & $\begin{array}{r}18,566 \\
3,891\end{array}$ & 57,953 & $\begin{array}{l}68,280 \\
14,721\end{array}$ \\
\hline TOTAL & 43,533 & 60,544 & 14,420 & 22,457 & 57,953 & 83,001 \\
\hline TOTAL & \multicolumn{2}{|c|}{104,077} & \multicolumn{2}{|c|}{36,877} & \multicolumn{2}{|c|}{140,954} \\
\hline PER CENT & 41.8 & 58.2 & 39.1 & 60.9 & 41.1 & 58.9 \\
\hline
\end{tabular}

In terms of the number of injuries for the two cities as summarized in the lower portion of Table 31, there were more total in juries of a multiple kind than there were single ones; overall about 60 per cent of the total wounds were multiple and 40 per cent occurred as single insults.

These figures say nothing about the ratio of single to multiple injuries in the dead which is unfortunate. However, it is known that the percentage of casulties were about the same for Hiroshima ( 33 per cent) and Nagasaki (34 per cent) in spite of the fact that a great deal of shielding was given by terrain in Nagasaki. Involved, at least, was the lower burst height in Nagasaki and higher levels of each of the effects parameters at the nearer ranges from ground zero; consequently, there could well have been more seriously injured survivors.

Since the overpressures were considerably higher at the closer ranges in Nagasaki (see Figures 28 and 29) than Hiroshima and all blast effects should have been enhanced, one would expect earlier and higher lethality among the immediate survivors in Nagasaki. Indeed such was the case. The figures show a mortality rate twice as high after the first day among the casualties for Nagasaki ( 40 per cent) compared with Hiroshima ( 21 per cent). It cannot be said, however, that these findings were due only to the pressure-range differences in Hiroshima and Nagasaki because other factors may have contributed as well; i.e., population density as it varied with range, the location of casualties at different ranges, the degree of shielding from both structures and terrain, and higher values for thermal and ionizing radiation over the areas nearer the hypocenter. 
Thus, regarding multiple injuries, it se ems fair to say in summary that there is ample reason to emphasize the need for learning as much as possible about how various levels of injury from overpressure combined with various levels of ionizing radiation, various impact velocities, various amounts of thermal radiation and various amounts of insult from penetrating and nonpenetrating debris. Neither should all combinations of insult from different doses of ionizing and thermal radiation be neglected. Some interest in studying the biological response to combined injury is evidenced in the literature $70-78$ with two recent publications originating in the USSR, 79,80 but progress to date has been neither broad nor impressive. It can be stated bluntly that without a systematic and extended research program in this area, the maximal amount of information about immediate effects will not flow from use of the Japanese data and neither will the understanding of the effects of nuclear explosions in general be as complete as it should be.

\section{Conditions of Exposure and Survival}

The over-all casualty figures referable to Hiroshima and Nagasaki given by Oughterson and Warten ${ }^{26}$ and by Oughterson et al. ${ }^{66}$ make it clear that the incidence of lethality, casualties and survival, including the uninjured of which there were about 119,000 of 255,000 exposed in Hiroshima and 110,000 of 174,000 in Nagasaki to use round numbers, depended critically, among other things, on the condition of exposure as well as range from the hypocenters. Indeed, unless the significance of "geometric" scaling as well as the range-effect relationship both are fully appreciated, it is surprising that more than $65,000^{*}$ in Hiroshima and $39,000^{*}$ in Nagasaki were not killed. Likewise, it is surprising that the living injured on the first day did not exceed the total recorded; namely, 91,000 and 42,000 for Hiroshima and Nagasaki, respectively.

To emphasize the general importance of the location of individuals at the time of the explosion, Figure 45, applicable to Hiroshima, 26 was prepared showing four survival curves as a function of range. From left to right, they apply to (a) over 2700 individuals exposed in concrete buildings said to be alive 20 days after the explosion, (b) persons located mostly inside school buildings, (c) the over-all average for the city and (d) school personnel in working parties who were mostly in the open at detonation time.

* The figures refer to the number dead in four months.

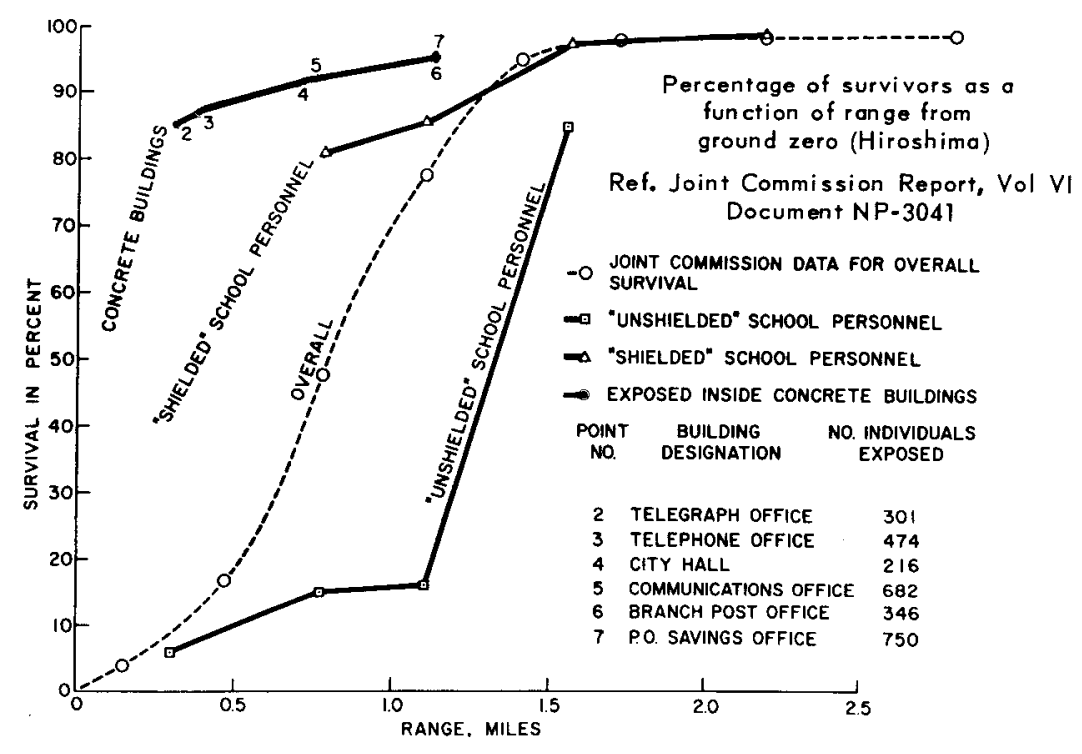

Figure 45 - Percentage of survivors as a function of range from GZ (Hiroshima) 
Since Figure 45, relating actual human experience with a nuclear de tonation, is highly interesting, a few comments are in order.

First, the quantitative relationship between immediate survival (20 days) and the conditions of exposure is remarkable. For example, the ranges for 85 -per cent survival were 0.3 , 1.0, 1.2 and 1.5 miles for concrete buildings, school houses, the over-all average, and for exposure in the open, respectively; the 50 -per cent survival ranges were 0.8 mile overall and 1.3 miles for unshielded individuals.

Second, wooden buildings were reduced to rubble out to about 1.5 miles in Hiroshima. However, over-all survival at this range was over 95 per cent and was depressed to a level of about 10 per cent at a range of 0.5 mile. Thus, there is a sharp difference betwe en the areas of physical and biological destruction and it is totally unrealistic to confuse the two.

Third, it is surprising that being inside concrete buildings compared with exposure in the open was associated with a five-fold difference in the ranges for 85-per cent survival, in spite of the fact that being in buildings enhanced the chances of injury from falling and flying debris. Apparently the latter hazard, even in houses, was relatively less than the dangers from direct thermal radiation.

Fourth, the differences in immediate survival noted above occurred by accident in Hiroshima. By chance, individuals inside and outside buildings were not exposed to one of the most far-reaching effects of the detonation, the thermal pulse, which was over in two or three seconds. By chance, persons were so situated inside structures to avoid high pressure reflections and the hazards of displacement and high velocity debris, events which were over and done with in an interval no longer than one to 20 seconds even out to a range of about three miles. By chance some individuals were shielded sufficiently from the prompt and delayed portion of the initial nuclear radiations, beginning with the flash and enduring no longer than several tens of seconds, to avoid untoward early symptoms of radiation sickness. By chance, over 200,000 people survived seconds and minutes with energy enough to help themselves, to give aid to others, to walk from the city ahead of the fires that bumed for hours and to seek food, shelter and medical help that materialized slowly but surely in the days and weeks following the explosion.

These facts highlighted the significance of immediate survival in Hiroshima. They promr one to ask how much survival might have been enhanced in both Japanese cities had there been a few minutes warning and had the population all simply moved indoors. Also, they prompt one to think realistically about the difference there could be between an exposure to serious environmental variations dictated on the one hand by chance and on the other hand by an organized plan conceived by perceptive individuals. Finally, the enhancement of survival associated with the geometry of exposure in Japan stimulates one to search for, identify and study all the relevant factors involved. Certainly, such an exercise, along with the thinking and relevant follow-on activities sure to ensue, will uncover much of fundamental interest, much that will contribute to environmental medicine, to industrial safety and to an enlightened understanding of the nuclear age which might yet dictate that protection of a population as well as long range missiles both represent significant parts of the complete equation which sooner or later must be written for national survival.

\section{DISCUSSION}

\section{A. BLAST EFFECTS}

Though many of the uncertainties concerning the use of tentative biological blast criteria for formulating an estimated range-effects relationship applicable to nuclear detonations varying widely in yield have been noted above, it is well to emphasize again that many revisions in thinking will become necessary in the future as additional data referable to the several problem areas become available. More specifically, this will surely be the case in assessing the potential 
biological blast effects for Hiroshima and Nagasaki. For one thing there is the unlikelihood that the explosive yield for both cities was identical and equal exactly to $20 \mathrm{kt}$. Also, more data are needed for specifying the biological hazards associated with exposure to disturbed wave forms and for scaling the translational velocities of animate and inanimate objects energized by the winds associated with atypical pressure pulses.

Thus, for these and other reasons the present study can only be regarded as illustrative of one quantitative approach aimed at relating biological and physical parameters to the end that primary, secondary, tertiary and eventually miscellaneous blast effects be properly and more thoroughly understood. Currently, therefore, it is the over-all method and scheme that the authors wish to emphasize and not necessarily the fixed numerical values of any of the included data. While many of the numbers used represent best current estimates, let all readers (a) understand their tentative nature, and (b) look to the future to provide information plagued by fewer uncertainties than is now the case.

\section{B. INITIAL IONIZING RADIATION}

As one means of emphasizing the last few statements noted above, it is instructive first to recall that the comparative or relative values for all the major effects parameters have great significance in interpreting the events that occurred after the Hiroshima and Nagasaki explosions and second to look at the available information for one effect; namely, initial nuclear radiations.

Figures 46 and $\mathbf{4 7}$ show free-field dose-distance curves for in itial nuclear radiations scaled from three sources for Hiroshima and Nagasaki, respectively, as follows:

1. Curves marked " $A$ " were computed from the data in The Effects of Nuclear Weapons" assuming that $20 \mathrm{kt}$ was a representative yield for both cities when the burst height was taken to be $1988 \mathrm{ft}$ (606 meters) for Hiroshima and $1575 \mathrm{ft}$ (480 meters) for Nagasaki.

2. Curves marked " $B$ " were scaled from the slant-range curves given in the next of Neel and Schull $\mathbf{B}^{*}$ for Hiroshima and Nagasaki. No mention was made either of the yield or the burst height that applied to each city. However the burst heights noted in paragraph one above were assumed to be representative and it was thus possible to compute dose-range figures from the hypocenters outward. The neutron and gamma curves - those marked " $B_{n}$ " and $B \gamma^{\prime}$, respectively - shown in Figures 46 and 47 were both taken from Neel and Schull. ${ }^{8}{ }^{1}$ In computing total dose, the figures for neutrons and gamma rays were simply added; i.e., the RBE was assumed to be one.

3. Curves marked "C" were prepared using the York curves as reproduced by Ritchie and Hurst. : $^{* *}$ while these are presumably the same as the York curves published by Hollingsworth et $\mathbf{1}^{65}$ and Arakawa ${ }^{82}$, 83 who has given 500 meters ${ }^{82}$ and 490 meters ${ }^{83}$ as the burst heights for Nagaski and 606 meters for Hiroshima, there was no statement concerning either the yield or the burst height figures used in arriving at the ground range data attributed initially to York. The latter fact partly explains why the " $\mathrm{C}$ " curves do not extend all the way in to the hypocenters.

As far as the literature is concerned, Figures 46 and 47 demonstrate very well that the information now available specifying range-dose data for in itial nuclear radiations referable to Hiroshima and Nagasaki needs refinement if at all possible. Even so, all the curves for total dose agree fairly well at the greater ranges and at the hypocenter are within a factor of 1.5 for Hiroshima, a figure that is better than the factor of two span stated by Arakawa 82,83 as the range of accuracy which should be applied to the York curves. However, for Nagasaki the estimates for total dose at the hypocenter vary by about a factor of four.

\footnotetext{
* Page 51 of reference 81 .
}

** Pages 400-401 of reference 12 . 


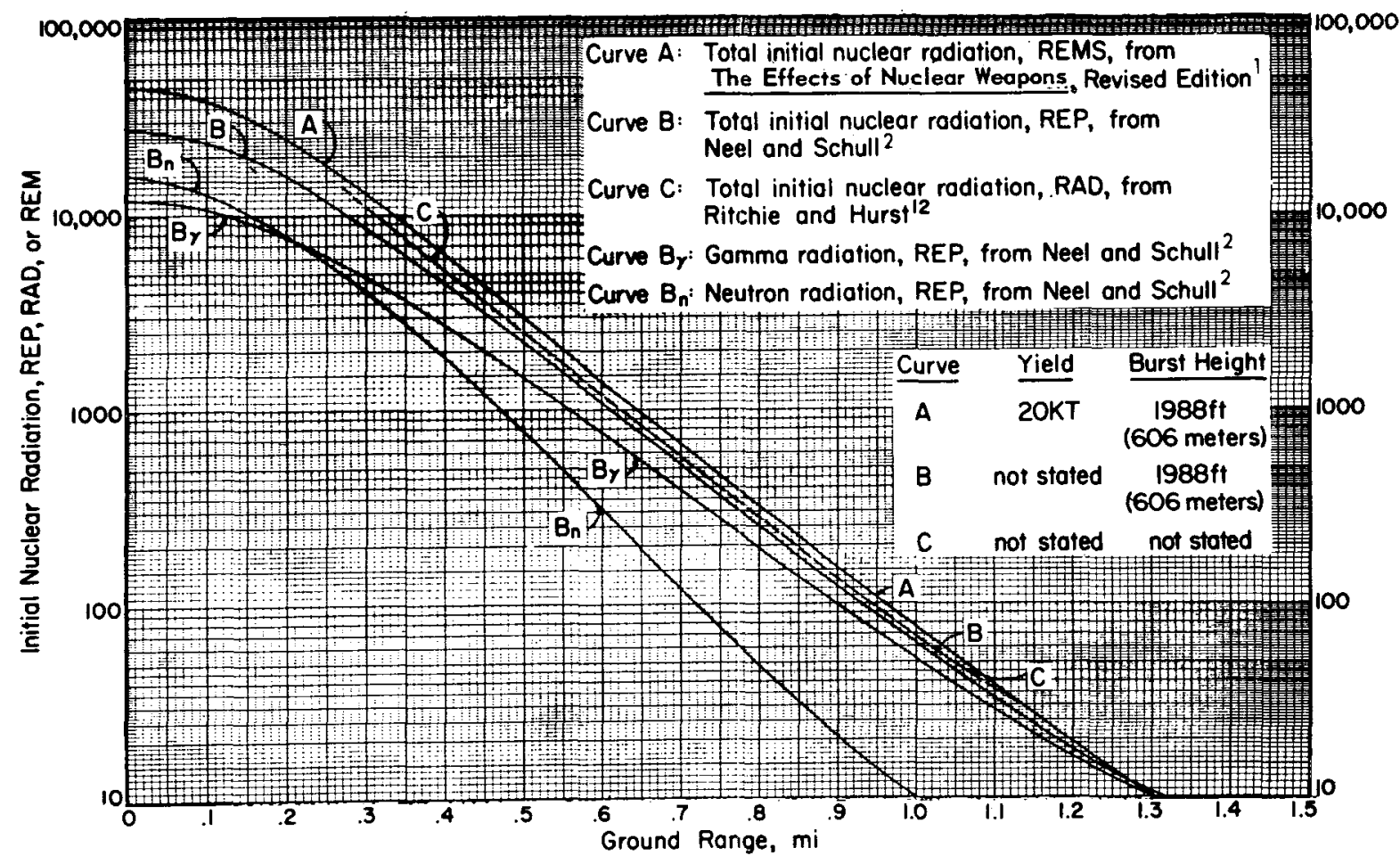

Figure 46 -Dose-range relation for initial nuclear radiation at Hiroshima

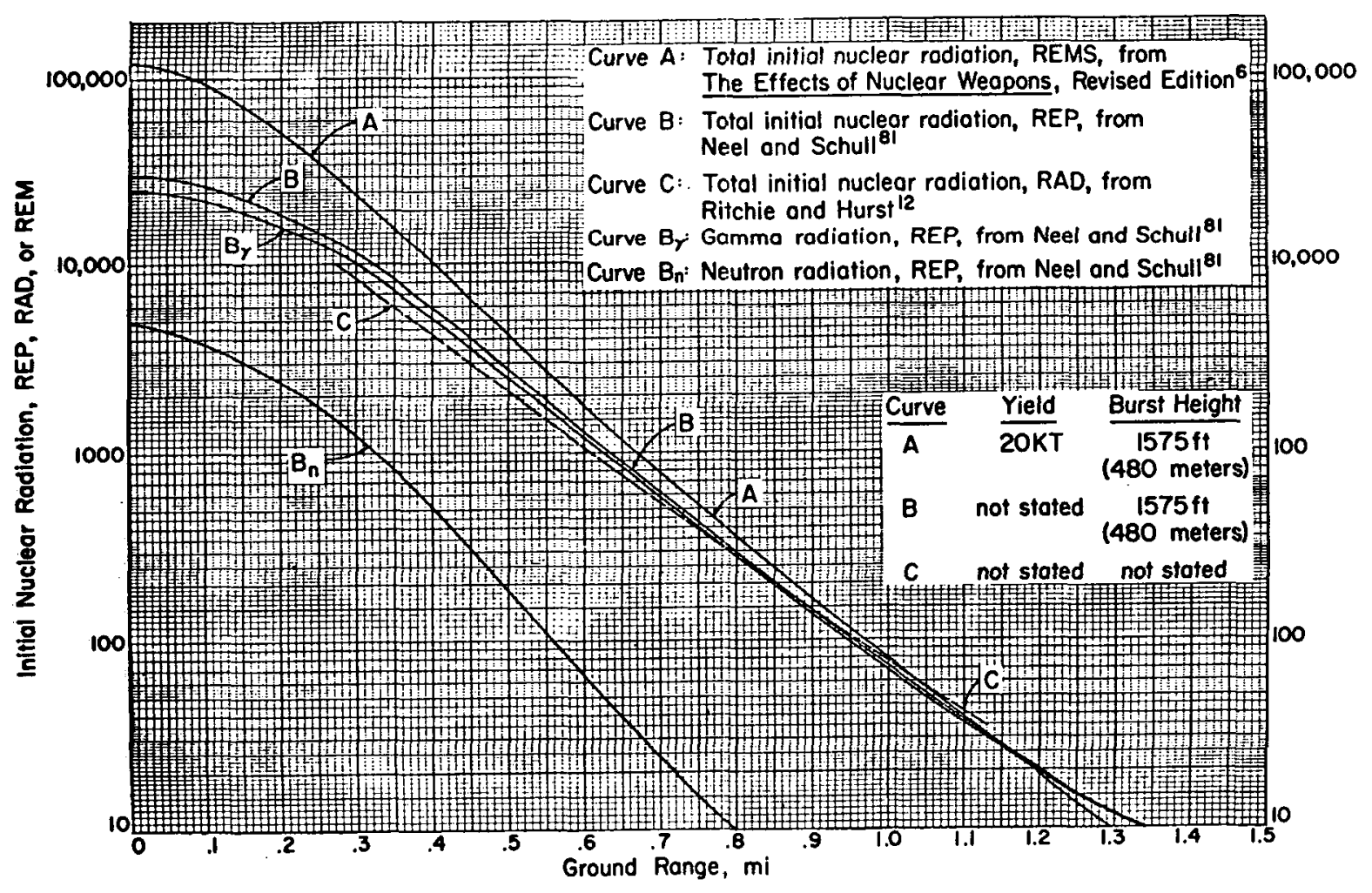

Figure 47 -Dose-range relation for initial nuclear radiation at Nagasaki 
While these matters are under current study in Japan 84 and by Oak Ridge personnel in the United States ${ }^{8-87}$ and better estimates will no doubt be forthcoming in due course, it is well to point out again that all the numbers noted in the present study for initial ionizing radiations including those tabulated in Tables 12-24 and 25-28 to illustrate the comparative relationship among the major effects data were scaled from Glasstone ${ }^{6}$ and thus are consistent with the curves labeled " $A$ " in Figures 46 and 47 for Hiroshima and Nagasaki, respectively. Those wishing to use the scaled radiation numbers of York or Neel and Schull may easily do so by referring to curves " $C$ " and " $B$ " in Figures 46 and 47.

\section{COMPARATIVE EFFECTS DATA SUMMARY}

In contemplating the over-all significance of comparative effects parameters scaled in the present study, it is helpful to note Figures 48 and 49 - which for Hiroshima and Nagasaki, respectively - summarize the free-field effects-range data for overpressure, translational velocities for mán and window-glass fragments, thermal radiation and initial nuclear radiations when the latter refers to doses scaled from The Effects of Nuclear Weapons; i.e., they are consistent with curves " $A$ " in Figures 46 and 47 . Since all the curves are labeled, the reader will have little difficulty in appreciating the several range-effects relationships providing it is unders tood that the ordinates or log scales are arbitrary and refer to the units andvalues noted for each of several curves.

Also, it is significant that charts such as those in Figures 48 and 49 can be prepared for any specific yield and burst condition for which effects data are currently available. The approach illustrated offers an interesting graphical means of portraying comparative-effects data across the range-yield spectrum, and while based on simple though tedious scaling laws, the procedure can be of considerable value in elucidating the interplay of the potentially hazardous phenomena that can follow detonation of nuclear explosives. The quantitative utility of such exercises of course depends upon the validity of the effects information employed, but these matters do not degrade the merit of free-field scaling carried out for comparative and relative assessment of potential hazards.

\section{SUMMARY}

A. The problem areas interesting those who would establish a quantitative relation between biological response and various levels of all the environmental variations that follow nuclear detonations were defined. On the physical side, these encompassed:

1. Information about the energy source and the factors which influence free-field scaling to set forth the range-effects relationship.

effects.

2. "Geometric" scaling whereby the conditions of exposure may modify the free-field

3. Secondary events wherein energy transfer to animate and ininanimate objects occur.

The biologically oriented problem areas included:

1. Biophysical interaction involving energy dissipation by or within biological media as these influence etiologic mechanisms.

2. Biologic response to single and combined injury and the biomedical tasks related thereto.

3. Hazards assessment and the formulation of protective measures and procedures. 


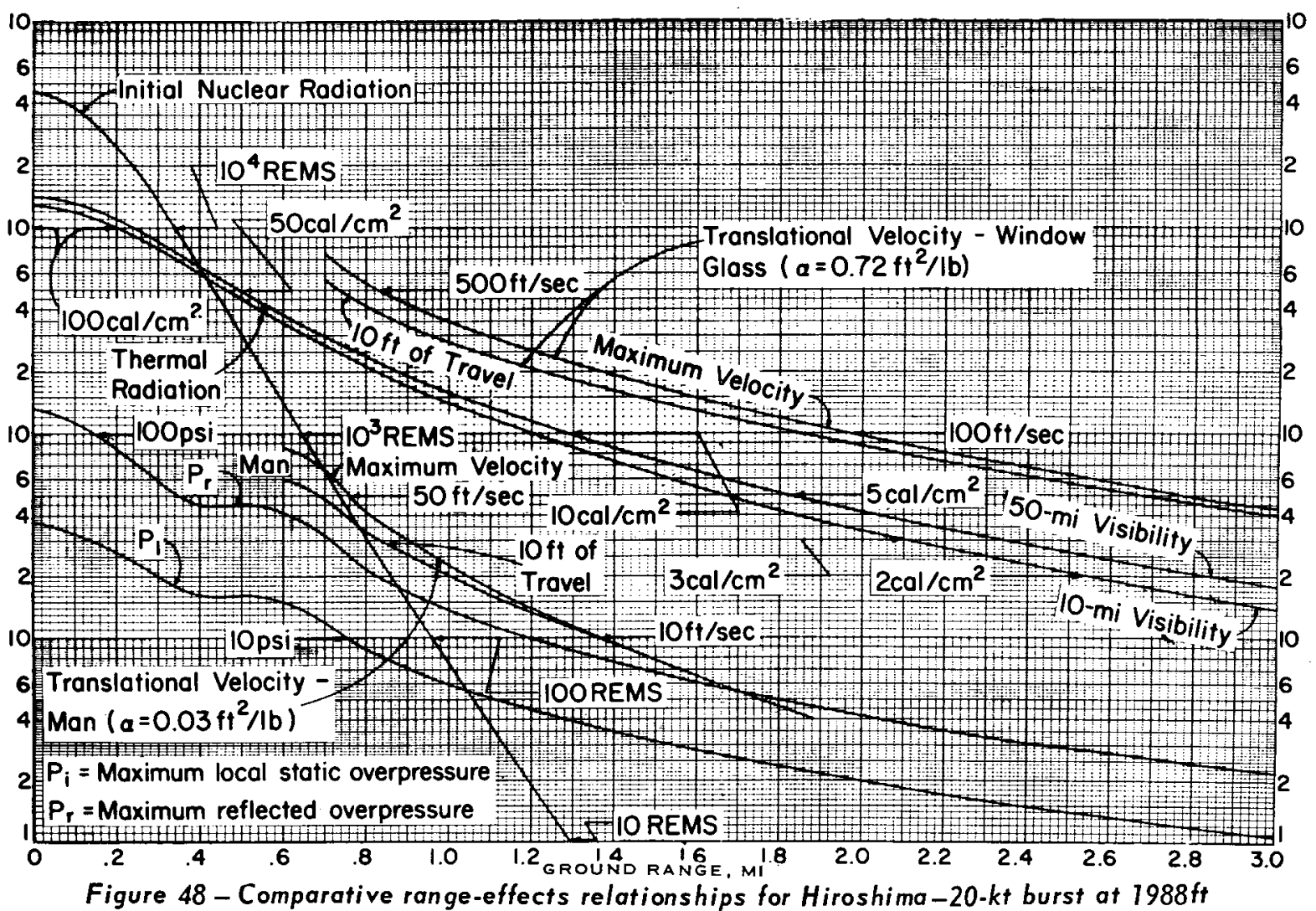

Figure 48 - Comparative range-effects relationships for Hiroshima-20-kt burst at $1988 \mathrm{ft}$ (606m) above sea-level terrain

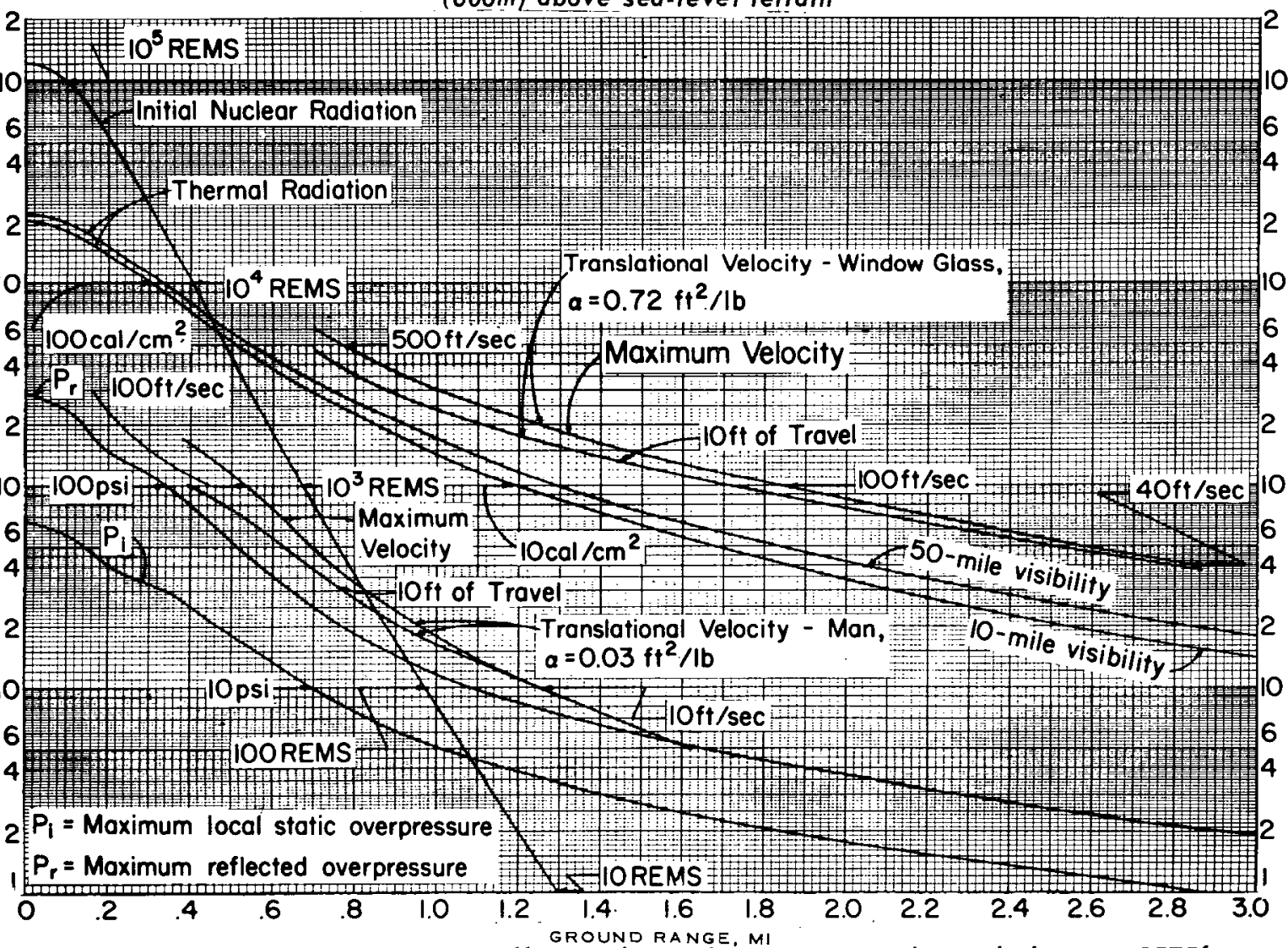

Figure 49 - Comparative range-effects relationships for Nagasaki-20-kt burst at $1575 \mathrm{ft}$ $(480 \mathrm{~m})$ above sea-level terrain 
B. The scope of blast and shock biology was set forth as follows:

1. Primary effects include the response to various blast-induced variations in environmental pressure.

2. Secondary effects involve damage due to the impact of penetrating or nonpenetrating debris energized by blast phenomena.

3. Tertiary effects encompass the potential hazards of total-body displacement by blast pressures, winds and ground shock and sometimes by gravity.

4. Miscellaneous effects are those due to dust, blast-induced fires, and non-line-of-site thermal burns from hot gases, dust and other debris.

C. Selected data regarding blast effects in mammals were summarized and tentative biologic criteria for human tolerance were set forth as follows:

1. Primary blast efiects following exposure to typical and atypical pulses of overpressure were stated to be different.

a. For "clean" wave forms:

1) Tolerance was noted to depend upon the magnitude and the duration of the overpressure as well as upon animal size.

2) The pressure-duration relationship for six mammalian species was set forth for "fast"-rising overpressures to show that (a) there was a critical pressure duration shorter than which the lethal pressure rose significantly and longer than which only the magnitude of the overpressure was important, (b) the critical duration was a function of animal size and (c) extrapolation of the data to the $70-\mathrm{kg}$ mammal revealed tolerance to be relatively low, intermediate and high, depending upon whether the pulse duration was long, intermediate or short, respectively.

3) Based on interspecies studies, human tolerance was arbitrarily set forth for "fast"-rising, "long"-duration overpressures as follows:

a) Lethality near 100 per cent - 58-80 psi (19-25 psi)

Lethality near 50 per cent - 42-57 psi (15-19 psi)

Lethality threshold $-30-42$ psi (12-15 psi)

b) Lung damage threshold - $15 \mathrm{psi}$ (6.4 psi)

c) Eardrum failure threshold - 5 psi (2.3 psi)

(The figures in parentheses show the incident overpressure that will reflect maximally to give the other overpressures shown.)

b. For atypical or disturbed wave forms, it was noted that:

1) The mammal was extraordinarily sensitive to the average rate of pressure rise and biological response was not yet adequately understood.

2) In the case of pressure increase in two "fast"-rising steps, tolerance depending upon the magnitude of each stepwise increase in pressure and the time between pulseswas known to increase by about 60 per cent.

3) Within certain ranges of stepwise increases in overpressure, a maximal overpressure producing fatality when applied almost instaneously would not prove lethal if there were sufficien ${ }^{\prime}$ delay between the first' and second pulse.

4) For smoothly rising overpressures reaching a maximum in greater than $30 \mathrm{msec}$, mammalian tolerance is known to increase by factors of betwe en two and five. 
5) Relatively high overpressures may or may not prove fatal depending mostly upon the character of the rising phase of the pressure pulse; i.e., minimal overpressures as sociated with lethality are "fast"-rising.

c. The nature of critical primary blast injuries was reviewed selectively and it was noted that:

1) Pathology typically occurs at or near the junction of tissues of different densities, particularly the air-containing organs.

2) The lung is the most critical organ and damage is followed by highly dangerous sequelae; namely, vascular air embo!i to the heart, brain and other organs; massive pulmonary hemorrhage and edema; and direct trauma to the heart.

3) Early and rapid lethality characterizes exposures to "fast"-rising overpressures of sufficient magnitude.

4) Post-exposure exercise and activity are contraindicated in cases of significant blast injury to the lung; i.e., exercise may precipitate a fatal outcome in instances that would recover with complete rest.

d. The need for further information concerning critical portions of biological response in the primary effects area was pointed out to encompass:

1) Tolerance to atypical wave forms including elucidation of the significance of the rate and character or the rising phase of the overpressure.

2) Tolerance in the very young and very old.

3) Biological blast scaling since a few data in mice indicate that lower overpressures are tolerated at altitude than at sea level; i.e., the ambient pressure at which exposure occurs is an important factor.

4) Empirical and theoretical biophysical studies to further clarify the fundamental principles responsible for biological damage.

5) Exploration of all possible protective measures, procedures and devices to mitigate the early lethality characterizing the primary-blast and impact syndromes.

6) The alteration in tolerance as a consequence of combining the challenge from overpressure, missile and impact and by adding nuclear and thermal radiations to blast phenomena.

2. To illustrate one common secondary blast effect, damage from glass fragments, data were presented showing the impact velocity-mass relationship as this influenced the probability of penetrating about one $\mathrm{cm}$ of soft tissue. On the basis of these and other published results, tentative biological criteria were established as follows:

a. For window-glass fragments weighing about $10 \mathrm{gms}$ :

Serious wounds

Near 100 per cent

$300 \mathrm{ft} / \mathrm{sec}$

Near 50 per cent

$180 \mathrm{ft} / \mathrm{sec}$

Threshold

$100 \mathrm{ft} / \mathrm{sec}$

Skin lacerations

$50 \mathrm{ft} / \mathrm{sec}$ 
b. For a blunt object (stone) weighing near $10 \mathrm{lb}$ :

Skull fracture

$\begin{array}{lc}\text { Near } 100 \text { per cent } & 23 \mathrm{ft} / \mathrm{sec} \\ \text { Threshold } & 15 \mathrm{ft} / \mathrm{sec} \\ \text { Mostly "safe" } & 10 \mathrm{ft} / \mathrm{sec} \\ \text { Cerebral concus sion } & \\ \text { Threshold } & 15 \mathrm{ft} / \mathrm{sec} \\ \text { Mostly "safe" } & 10 \mathrm{ft} / \mathrm{sec}\end{array}$

3. To exemplify one of the most serious tertiary blast effects, results of an interspecies impact study were cited to:

a. Show that early and rapid lethality also characterizes the impact syndrome.

b. Help establish tentative biological criteria which were also based on other published data as follows:

1) Total body impact

$\begin{array}{ll}\text { Lethality near } 100 \text { per cent } & 30 \mathrm{ft} / \mathrm{sec} \\ \text { Lethality near } 50 \text { per cent } & 26 \mathrm{ft} / \mathrm{sec} \\ \text { Lethality threshold } & 20 \mathrm{ft} / \mathrm{sec} \\ \text { Mostly "safe" } & 10 \mathrm{ft} / \mathrm{sec}\end{array}$

2) Skull fracture

$\begin{array}{ll}\text { Near } 100 \text { per cent } & 23 \mathrm{ft} / \mathrm{sec} \\ \text { Near } 50 \text { per cent } & 18 \mathrm{ft} / \mathrm{sec} \\ \text { Threshold } & 13 \mathrm{ft} / \mathrm{sec} \\ \text { Mostly "safe", } & 10 \mathrm{ft} / \mathrm{sec}\end{array}$

D. The free-field range-yield-effects relationship was presented to illustrate (a) how the range of the major effects parameters varied with explosive yield and (b) the application of tentative biological criteria across the range-yield spectrum. Attention was called to the fact that events referable to the Japanese explosion, except in very carefully assessed circumstances, applied mostly to the $20-\mathrm{kt}$ portion of the range-yield-effects diagram. The relations between overpressures and initial nuclear radiation as these varied with explosive yield were graphically portrayed to emphasize that the higher the yield, the lower was the level of initial nuclear radiation associated with a given overpressure, a fact that adds significance to understanding the immediate effects in Japan.

E. The tentative biological blast criteria along with those for thermal (first and second degree burns) and initial nuclear radiation (100-200 rem) were applied to the Japanese explosions on the basis of free-field and translational (secondary events) scaling following data given mostly in the 1962 edition of The Effects of Nuclear Weapons ${ }^{6}$ assuming that a 20-kt yield was representative for both cities and that the burst height was $1988 \mathrm{ft}$ (606 meters) for Hiroshima and $1575 \mathrm{ft}$ (480 meters) for Nagasaki. The range-effects data so obtained revealed the following predicted ranges inside which the potential existed for producing specified levels of damage: 


\section{FOR HIROSHIMA}

\begin{tabular}{|c|c|c|c|c|}
\hline BIOLOGICAL EVENT OR EFFECT & $\begin{array}{l}\text { RANGE, } \\
\text { mile }\end{array}$ & $P_{\text {MAX }}$ & $\begin{array}{l}\text { THERMAL } \\
\text { RADIATION, } \\
\mathrm{col} / \mathrm{cm}^{2}\end{array}$ & $\begin{array}{l}\text { INITIAL } \\
\text { NUCLEAR } \\
\text { RADIATION, } \\
\text { rem }\end{array}$ \\
\hline Effects of hypocenter & 0 & 37 & 127 & 45,000 \\
\hline Primary blast lethality threshold without pressure reflection & 0.14 & 30 & 110 & 33,000 \\
\hline Lung-domage threshold without pressure reflection & 0.58 & 15 & 35 & 1,500 \\
\hline Primary blost lethality threshold with maximum pressure reflection & 0.70 & 12 & 26 & 660 \\
\hline Initial nuclear-radiation-injury threshold & 0.96 & 6.5 & 15 & 100 \\
\hline Lungedomage threshold with maximum pressure reflection & 0.96 & 6.5 & 15 & 100 \\
\hline Impoct-total body, letholity threshold & 1.00 & 6.0 & 14 & 75 \\
\hline Skull-fracture threshold ( $10.1 \mathrm{~b}$ stone) & 1.02 & 5.8 & 13 & 66 \\
\hline Skull-fracture threshold (impact) & 1.22 & 4.3 & 9 & $<17$ \\
\hline Second-degree burns & 1.74 & 2.4 & 4.5 & $<10$ \\
\hline Serious wounds from $10 . \mathrm{gm}$ glass fragments, threshold & 1.84 & 2.3 & 4.1 & $<10$ \\
\hline First-degree burns & 2.31 & 1.8 & 2.5 & $<10$ \\
\hline Skin lacerations from $10-\mathrm{gm}$ glass frogments, threshold & 2.7 & 1.3 & 1.8 & $<10$ \\
\hline
\end{tabular}

\section{FOR NAGASAKI}

\begin{tabular}{|c|c|c|c|c|}
\hline BIOLOGICAL EVENT OR EFFECT & $\begin{array}{l}\text { RANGE, } \\
\text { mile }\end{array}$ & $\begin{array}{c}P_{\text {MAX }} \\
\text { psi }\end{array}$ & $\begin{array}{c}\text { THERMAL } \\
\text { RADIATION, } \\
\mathrm{col}^{2} \mathrm{~cm}^{2}\end{array}$ & $\begin{array}{c}\text { INITIAL } \\
\text { NUCLEAR } \\
\text { RADIATION, } \\
\text { rem }\end{array}$ \\
\hline Effects at hypocenter & 0 & 66 & 204 & 122,000 \\
\hline Primary blast lethality threshold without pressure reflection & 0.34 & 30 & 84 & 17,000 \\
\hline Primary blast lung injury threshold without pressure reflection & 0.56 & 15 & 41 & 2,600 \\
\hline Primary blast lethality threshold with maximum pressure reflection & 0.65 & 12 & 27 & 1,200 \\
\hline Primary blast lung injury threshold with pressure reflection & 0.88 & 6.5 & 18 & 190 \\
\hline Impact - total body, lethality threshold & 0.91 & 6.0 & 17 & 150 \\
\hline Skull fracture - 10.16 stone - threshold & 0.93 & 5.8 & 17 & 130 \\
\hline Initial nuclear radiation injury threshold & 0.97 & 5.4 & 15 & 100 \\
\hline Skull fracture - impoct threshold & 1.12 & 4.3 & 11 & 34 \\
\hline Serious wounds from $10 . \mathrm{gm}$ glass frogments threshold & 1.70 & 2.3 & 4.8 & $<10$ \\
\hline Secondedegree burns & 1.92 & 1.9 & 4.5 & $<10$ \\
\hline Skin lacerations from $10-\mathrm{gm}$ glass fragments, threshold & 2.51 & 1.25 & 2.6 & $<10$ \\
\hline Firstadegree burns & 2.56 & 1.2 & 2.5 & $<10$ \\
\hline
\end{tabular}


F. The implications of the free-field range-effects data scaled and predicted for Hiroshima and Nagasaki were discussed; in particular, it was noted that:

1. The general approach taken was considered valid even though detailed quantitative data are subject to future refinements.

2. The specific application of the range-effects data to the experience in Japan depends a great deal upon two matters; namely, (a) the influence the geometry and other conditions of exposure had in altering the free-field effects parameters, for it is the environmental variations that occur at the location of biological targets that in truth determine the presence or absence of a hazard and (b) the ability to segregate by one means or another all blast, thermal and nuclear radiation effects from one another.

3. Data regarding the 20-day-survivor sample in Hiroshima and Naga saki must be interpreted with great care, for only individuals well enough protected to move out of the city reached medical channels, and, consequently, the incidence of highly hazardous primary and tertiary blast effects alone and in combination with thermal and ionizing radiation damage among those who died at once was and is incompletely revealed by data collected on survivors.

4. There was an immediate and delayed lethality among individuals exposed at relatively close ranges in the Bankers' Club at Hiroshima and in the Chinzei School at Nagasaki, and the potential for employing such experience to leam more about human tolerance to nuclear blast phenomena and to combined injury was pointed out and emphasized.

5. Employing an "equivalence" concept offers a promising means of applying Iliroshima and Nagasaki survival and lethality data to higher explosive yields.

6. Non-line-of-site thermal burns due to hot, dust-laden air and debris promises to be a major hazard from high-yield nuclear explosions and attention was called to the need for more biological data than the few cited and known to the authors.

7. Much more work in the areas of single and combined injuries offers one very important means of improving interpretation of the human experience following the Japanese explosions.

8. Since the geometry and conditions of exposure by accident markedly influenced survival following the nuclear detonations over Hiroshima and Nagasaki and because there was a great difference between the areas of physical and biological destruction in both cities, the need for identifying all the factors mitigating lethality and enhancing immediate survival was emphasized.

9. Relevant survival curves for Hiroshima were presented to highlight the difference there could be between exposure to hazardous environmental variations dictated on the one hand by chance and on the other hand by an organized plan conceived by knowledgeable and perceptive individuals.

G. In briefly discussing the uncertainties in the comparative effects data, emphasis was placed upon the analytical methodology employed and upon the tentative nature of the numerical data currently at hand. As an example, free-field dose-distance curves for initial nuclear radiations were presented from three sources available in the literature to allow appreciation of the need for further refining effects-range information. Finally, over-all summary charts of the range-effects data scaled for the present study were included to emphasize the importance of a balanced approach to nuclear effects to the end that all hazardous parameters be placed in proper perspective on a quantitatively comparative basis. 


\section{REFERENCES}

1. White, C. S., "Biological Effects of Blast," presented before The Amed Forces Medical Symposium, Field Command, Defense Atomic Support Agency, Sandia Base, Albuquerque, New Mexico, November 28, 1961, Technical Progress Report No. DASA 1271, Defense Atomic Support Agency, Department of Defense, Washington 25, D. C., December 1961.

2. Bowen, I. G., P. B. Woodworth, Mary E. Franklin and C. S. White, "Translational Effects of Air Blast from High Explosives," in Proceedings of the Symposium on Effectiveness Analysis Tecbniques for Non-Nuclear Warbeads against Surface Targets, October 30-31, 1962, Vol. 1, pp M to M-61, U. S. Naval Weapons Laboratory, Dahlgren, Virginia. Technical Progress Report No. DASA 1336, Defense Atom ic Support Agency, Department of Defense, Washington 25, D.C., November 7, 1962.

3. White, C. S., I. G. Bowen and D. R. Richmond, "The Environmental Medical Aspects of Nuclear Blast," presented before the National Preparedness Symposium sponsored by The National Institute for Disaster Mobilization, Inc., Washington, D. C., on November 13, 1962. Technical Progress Report No. DASA 1341, Defense Atom ic Support Agency, Department of Defense, Washington 25, D. C., November 1962.

4. Glasstone, S., Editor, The Effects of Atomic Weapons, U. S. Govemment Printing Office, Washington 25, D. C., June 1950.

5. Glasstone, S., Editor, The Effects of Nuclear Weapons, U. S. Govemment Printing Office, Washington 25, D. C., June 1957.

6. Glasstone, S., Editor, The Effects of Nuclear Weapons, Revised Edition 1962, Superintendent of Documents, U. S. Govemment Printing Office, Washington 25, D. C., April 1962.

7. White, C. S., I. G. Bowen, D. R. Richmond and R. L. Corsbie, "Comparative Nuclear Effects of Biomedical Interest," USAEC Civil Effects Test Operations Report, CEX-58:8, Office of Technical Services, Department of Commerce, Washington 25, D. C., January 12, 1961.

8. White, C. S., T. L. Chiffelle, D. R. Richmond, W. H. Lockyear, I. G. Bowen, V. C. Goldizen, H. W. Merideth, D. E. Kilgore, B. B. Longwell, J. T. Parker, F. Sherping and M. E. Cribb, "The Biological Effects of Pressure Phenomena Occurring Inside Protective Shelters Following Nuclear Detonation," USAEC Civil Effects Test Group Report, WT-1179, Office of Technical Services, Department of Commerce, Washington 25,

D. C., October 28, 1957.

9. Vortman, L. J., "Evaluation of Various Types of Personnel Shelters Exposed to an Atomic Explosion," AEC Civil Effects Test Group, Report WT-1218, Office of Technical Services, Department of Commerce, Washington 25, D. C., May 1956.

10. Richmond, D. R., R. V. Taborelli, I. G. Bowen, T. L. Chiffelle, F. G. Hirsch, B. B. Longwell, J. G. Riley, C. S. White, F. Sherping, V. C. Goldizen, J. D. Ward, M. B. Weth erbe, V. R. Clare, M. L. Kuhn and R. T. Sanchez, "Blast Biology - A Study of the Primary and Tertiary Effects of Blast in Open Underground Protective Shelters," USAEC Civil Effects Test 
(iroup Report. WT-146-, Office of Technical Services, Department of Commerce, Hashington 25. D. C., June 30, 1959.

11. Richmond, D. R., C. S. White, R. T. Sanchez and F. Sherping, "The Internal Environment of Inderground Structures Subjected to Nuclear Blast. II. Effects on Mice Located in Heavy Concrete Shelters," USAEC Civil Effects Test Group Report, WT-1507, Office of Technical Services, Department of Comm erce, Washington 25, D. C., May 31, 1960.

12. Ritchie, R. H. and G. S. Hurst, "Penetration of Weapons Radiation: Application to the Hiroshima-Nagasaki Studies," Healtb Pbysics, 1:390-404, 1959.

13. Auxier, J. A., J. O. Buchanan, C. Eisenhauer and H. E. Menker, "Experimental Evaluation of the Radiation Protection Afforded by Residential Structures Against Distributed Sources," Oak Ridge National Laboratory and Division of Biology and Medicine, USAEC Civil Effects Test Operations Report, CEX-58.1, Office of Technical Services, Department of Commerce, Washington 25, D. C., January 19, 1959.

14. Strickler, T. D. and J. A. Auxier, "Experimental Evaluation of the Radiation Protection Afforded by Typical Oak Ridge Homes Against Distributed Sources," Oak Ridge National Laboratory, USAEC Civil Effects Test Operation Report, CEX-59.13, Office of Technical Services, Department of Commerce, Washington 25, D. C., April 14, 1960.

15. Batter, J. F., Jr., A. L. Kaplan and E. T. Clarke, "An Experimental Evaluation of the Radiation Protection Afforded by a Large Modem Concrete Office Building," USAEC Civil Effects Test Operations Report, CEX-59.1, Office of Technical Services, Department of Commerce, Washington 25, D. C., January 22, 1960.

16. Borella, H., Z. Burson and J. Jacovitch, "Evaluation of the Fallout Protection Afforded by Brookhaven National Laboratory Medical Research Center," USAEC Civil Effects Test Operation Report, CEX-60.1, Office of Technical Services, Department of Commerce, Washington 25, D. C., October 1961.

17. Burson, Z., D. Parry and H. Borella, "Experimental Evaluation of the Fallout-Radiation Protection Afforded by a Southwestern Residence," USAEC Civil Effects Test Operation Report, CEX-60.5, Office of Technical Services, Department of Commerce, Washington 25, D. C., February 1962.

18. Burson, Z. and H. Borella, "Experimental Evaluation of the Radiation Protection Provided by an Earth-Covered Shelter, "USAEC Civil Effects Test Operation Report, CEX-60.6, Office of Technical Services, Department of Commerce, Washington 25, D. C., February 1962.

19. Zuckerman, S., "The Problem of Blast Injuries," Proc. Roy, Soc. Med., XXXIV: 171-188, 1941.

20. White, C. S., "Biological Blast Effects," Hearings before the Special Subcommittee on Radiation of the Joint Committee on Atomic Energy, Congress of the United States, EightySixth Congress, First Session on Biological and Environmental Effects of Nuclear War, Part 1, pp. 311-372, June 22-26, 1959, U. S. Government Printing Office, 1959.

21. Wite, C. S., "Biological Blast Effects," USAEC Technical Report, TID-5564, Office of Technical Services, Department of Commerce, Washington 25, D. C., September 1959.

22. White, C. S. and D. R. Richmond, "Blast Biology," USAEC Technical Report TID-5764, Office of Technical Services, Department of Commerce, Washington 25, D. C., September 18, 1959.

23. White, C. S. and D. R. Richmond, "Blast Biology," Chapter 63 in Clinical Cardiopulmonary physirirgy, edited by Ross C. Kory, and Burgess L. Gordon, Grune and Stratton, Inc., New York, 1960. 
24. Desaga, Hans, "Experimental Investigations of the Action of Dust," Chapter XIII-B, pp. $1188-$ 1203, German Aviation Medicine, World War II, Vol. II, U. S. Government Printing Office, Vashington, 1950.

25. White, C. S., M. B. Wetherbe and V. C. Goldizen, "The Internal Environment of Underground Structures Subjected to Nuclear Blast. I. The Occurrence of Dust," USAEC Civil Effects Test Group Report, ITR-1447, Office of Technical Services, Department of Commerce, Washington 25, D. C., November 22, 1957.

26. Oughterson, Ashley and Shields Warren, Editors, Medical Effects of the Atomic Bomb in Japan, First Edition, McGraw-Hill Book Company, Inc., New York, Toronto, London, 1956.

27. Roberts, J. E., C. S. White and T. L. Chiffelle, "Effects of Overpressures in Group Shelters on Animals and Dummies," USAEC Civil Effects Test Group Report, WT-798, Office of Technical Services, Department of Commerce, Washington 25, D. C., September 1953.

28. Greig, A. L. and H. E. Pearse, "Thermal Radiation Mea surements (Parts I and II)," Operation Plumbbob Report, ITR-1502, Office of Technical Services, Department of Commerce, Wa shington 25, D. C., January 1958.

29. Davis, T. P., N. D. Miller, T. S. Ely, J. A. Basso and H. E. Pearse, "The Scattering of Thermal Radiation Into Open Underground Shelters," USAEC Civil Effects Test Operations Report, CEX-58.2, Office of Technical Services, Department of Commerce, Washington 25, D. C., May 1959.

30. Richmond, D. R., R. V. Taborelli, F. Sherping, M. B. Wetherbe, R. T. Sanchez, V. C. Goldizen and C. S. White, "Shock Tube Studies of the Effects of Sharp-Rising, Long-Duration Overpressures on Biological Systems," USAEC Technical Report, TID-6056, Office of Technical Services, Department of Commerce, Washington 25, D. C., March 10, 1959.

31. Bowen, I. G., D. R. Richmond, M. B. Wetherbe and C. S. White, "Biological Effects of Blast from Bombs. Glass Fragments as Penetrating Missiles and Some of the Biological Implications of Glass Fragmented by Atomic Explosions, "USAEC Report, AECU-3350, Office of Technical Services, Department of Commerce, Washington 25, D. C., June 18, 1956.

32. Goldizen, V. C., D. R. Richmond, T. L. Chiffelle, I. G. Bowen and C. S. White, "Missile Studies with a Biological Target," USAEC Civil Effects Test Group Report, WT-1470, Office of Technical Services, Department of Commerce, Washington 25, D. C., January 23, 1961.

33. Richmond, D. R., I. G. Bowen and C. S. White, "Tertiary Blast Effects: Effects of Impact on Mice, Rats, Guinea Pigs and Rabbits," Technical Progress Report No. DASA 1245, Defense Atomic Support Agency, Department of Defense, Washington 25, D. C., February 28, 1961. Also in Aerospace Med., 32: 789-805, 1961.

34. Richmond, D. R., V. R. Clare, V. C. Goldizen, D. E. Pratt, R. T. Sanchez and C. S. White, "Biological Effects of Overpressure. Il. A Shock Tube Utilized to Produce Sharp-Rising Overpressures of 400 Milliseconds Duration and Its Employment in Biomedical Experiments," Technical Progress Report No. DASA 1246, Defense Atomic Support Agency, Department of Defense, Washington 25, D. C., April 7, 1961. Also in Aerospace Med., 32: 997-1008, 1961.

35. Richmond, D. R., V. C. Goldizen, V. R. Clare, D. E. Pratt, F. Sherping, R. T. Sanchez, C. C. Fischer and.C. S. White, "Biologic Response to Overpressure. III. Mortality in Small Animals Exposed in a Shock Tube to Sharp-Rising Overpressures of 3 to $4 \mathrm{Msec}$ Duration," Technical Progress Report No. DASA 1242, Defense Atomic Support Agency, Department of Defense, Washington 25, D. C., June 15, 1961. Also in Aerospace Med., 33: 1-27, 1962.

36. Richmond, D. R., V. C. Goldizen, V. R. Clare and C. S. White, "The Overpressure-Duration Relationship and Lethality in Small Animals," Technical Progress Report No. D.SS.A 1325. Defense Atomic Support Agency, Department of Defense, Washington 25, D.C., September 10 , 1962. 
37. Richmond, D. R. and C. S. White, "A Tentative Estimation of Man's Tolerance to Over-pressures from Air Blast," in Proceedings of the Symposium on Effectiveness Analysis Techniques for Non-Nuclear War-heads against Surface Targets, October 30-31, 1962, Vol. 1, Pp. L to L-34, U. S. Naval Weapons Laboratory, Dahlgren, Virginia. Technical Progress Report No. DASA 1335, Defense Atomic Support Agency, Dept. of Defense, Washington 25, D. C., November 1962.

38. Fisher, R. B, P. L. Krohn and S. Zuckerman, "The Relationship Between Body Size and the Lethal Effects of Blast," Ministry of Home Security Report R. D. 284, Oxford University, Oxford, England, December 10, 1941.

39. Desaga, Hans, "Experimentelle Un tersuchungen der Luftstoszwirkung," Forschungsbericht 15/43. Mitteilungen aus dem Gebiet der Luftfahrtmedizin. Herausgegeben von Inspekteur des Sanitätswesens der Luftwaffe, 1943.

40. Desaga, Hans, "Blast Injuries," Chap. XIV-D, German Aviation Medicine, World War II, Vol. II, pp. 1274-1293, U. S. Government Printing Office, Washington 25, D. C., 1950.

41. Benzinger, T., "Physiological Effects of Blast in Air and Water," Chap. XIV-B, German Aviation Medicine, World War II, Vol. II, pp. 1225-1259, U. S. Govt. Print. Off., Wash. 25, D.C., 1950

42. Schardin, H., "The Physical Principles of the Effects of a Detonation," Chap. XIV-A, German Aviation Medicine, World War II, Vol. II, Pp. 1207-1224,U. S.Govt. Print. Off., Wash. 25, D. C., 1950.

43. Schardin, H. and O. Wünsche, "Versuche an Kleintieren zur Bestimmung der Druckstossẗ̈dlichkeitsgrenze," Bericht V 17, Deutsche Versuchsanstalt für Luftfahrt e. V., January 1958.

44. Richmond, D. R., DASA Project, Lovelace Foundation for Medical Education and Research, Albuquerque, New Mexico, unpublished data.

45. Richmond, D.R., V. R. Clare and C. S. White, "The Tolerance of Guinea Pigs to Air Blast when Mounted in Shallow, Deep, and Deep-with- Offset Chambers on a Shock Tube," Technical Progress Report No. DASA 1334, Defense Atomic Support Agency, Department of Defense, Washinton 25, D. C., October 27, 1962.

46: Damon, E. G., DASA Project, Lovelace Foundation for Medical Education and Research, Albuquerque, New Mexico, personal communication.

47. Clare, V. R., D. R. Richmond, V. C. Goldizen, C. C. Fischer, D. E. Pratt, C. S. Gaylord and C. S. White, "The Effects of Shock Tube Generated Step-Rising Overpressures on Guniea Pigs Located in Shallow Chambers Oriented Side-On and End-On to the Incident Shock," Technical Progress Report No. DASA 1312, Defense Atomic Support Agency, Department of Defense, Washington 25, D. C., May 31, 1962.

48. Richmond, D. R., M. B. Wetherbe, R. V. Taborelli, T. L. Chiffelle and C. S. White, "The Biologic Response to Overpressure. I. Effects on Dogs of Five to Ten-Second Duration Overpressures Having Various Times of Pressure Rise," J. Aviat.Med., 28; 447-460, 1957.

49. Richmond, D. R., D. E. Pratt and C. S. White, 'Orbital 'Blow-Out' Fractures in Dogs Produced by Air Blast," Technical Progress Report No. DASA 1316, Defense Atomic Support Agency, Department of Defense, Washington 25, D. C., April 10, 1962.

50. Taborelli, R. V., AEC and DASA Projects, Lovelace Foundation for Medical Education and Research, Albuquerque, New Mexico, unpublished data.

51. Rössle, R., "Pathology of Blast Effects," Chap. XIV-C, German Avaition Medicine, World War II, Vol. II, pp. 1260-1273, U. S. Government Printing Office, Washington 25, D. C., 1950. 
52. Chiffelle, T. L., DASA Project, Lovelace Foundation for Medical Education and Research, Albuquerque, New Mexico, unpublished data.

53. Beyer, J. C., (Editor), Wound Ballistics, Office of the Surgeon General, Department of the Army, U. S. Government Printing Office, Washington 25, D. C., 1962.

54. Lissner, H. L. and F. G. Evans, "Engineering Aspects of Fractures," Clin. Orthop., 8: 310-322, 1958.

55. Zuckerman, S. and A. N. Black, "The Effect of impact on the Head and Back of Monkeys," Report R. C. 124, Ministry of Home Security, Oxford, England, August 12, 1940.

56. Gurdjian, E. S., J. E. Webster and H. L. Lissner, "Studies on Skull Fracture with Particular Reference to Engineering Factors," Amer. J. Surg., 78: 736-742, 1949.

57. Swearingen, J. J., E. B. McFadden, J. D. Garner and J. G. Blethrow, "Human Tolerance to Vertical Impact," Aerospace Med., 31:989-998, 1960.

58. Bowen, I. G., A. F. Strehler and M. B. Wetherbe, "Distribution and Density of Missiles from Nuclear Explosions," USAEC Civil Effects Test Group Report, WT-1168, Office of Technical Services, Department of Commerce, Washington 25, D. C., December 14, 1956.

59. Bowen, I. G., R. W. Albright, E. R. Fletcher and C. S. White, "A Model Designed to Predict the Motion of Objects Translated by Classical Blast Waves," USAEC Civil Effects Test Operations Report, CEX-58.9, Office of Technical Services, Department of Commerce, Washington 25, D. C., June 29, 1961.

60. Bowen, I. G., Mary E. Franklin, E. R. Fletcher and R. W. Albright, "Secondary Missiles Generated by Nuclear-Produced Blast Waves," USAEC Civil Effects Test Group Report, WT-1468, March 7, 1962, (in press).

61. Auxier, J. A., personal communication.

62. Fletcher, E.R., R. W. Albright, V.C. Goldizen and I. G. Bowen, "Determinations of Aerodynamic-Drag Parameters of Small Irregular Objects by Means of Drop Tests," USAEC Civil Effects Test Operations Report, CEX-59.14, Office of Technical Services, Department of Commerce, Washington 25, D. C., October 1961.

63. Fletcher, E. R., R. W. Albright, R. F. D. Perret, Mary E. Franklin, I. G. Bowen and C. S. White, "Nuclear Bomb Effects Computer (Including Slide-Rule Design and Curve Fits for Weapons Effects)," USAEC Civil Effects Test Operations Report, CEX-62.2, Office of Technical Services, Department of Commerce, Washington 25, D. C., February 15, 1963.

64. Taborelli, R. V. and I. G. Bowen, "Tertiary Effects of Blast - Displacement," USA EC Civil Effects Test Group Report, ITR-1469, Office of Technical Services, Department of Commerce, Washington 25, D. C., December 20, 1957.

65. Hollingsworth, J. W., G. W. Beebe, M. Ishida and A. B. Brill, "Medical Findings and Methodology of Studies by the Atomic Bomb Casualty Commission on Atomic Bomb Survivors in Hiroshima and Nagasaki," Proceedings of the Seminar sponsored by the United Nations and the World Health Organization, beld in Geneva September 5-9, 1960, A/AC.821 Seminar, pp 77-100, United Nations, New York, 1962.

66. Oughterson, A. W., G. V. LeRoy, A. A. Liebow, E. C. Hammond, H. L. Bamett, J. D. Rosenbaum and B. A. Schneider, "Medical Effects of Atomic Bombs - The Report of the Joint Commission for Investigation of the Effects of the Atomic Bomb in Japan," Vol. VI, AEC Technical Information Service, Oak Ridge, Tennessee, July 6, 1951. 
67. Oughterson, A. W'., G. V. LeRoy, A. A. Liebow, E. C. Hammond, H. L. Barnett, J. D. Rosenbaum and B. A. Schneider, "Medical Effects of the Atam ic Bomb - The Report of the Joint Commission for the Investigation of the Effects of the Atomic Bomb in Japan," Vol. II, AEC Document No. NP-3037, U.S. AEC Technical Information Service, Oak Ridge, Tennessee, April 19, 1951.

68. Lynch, F. Y., Armed Forces Institute of Pathology, personal communications.

69. Ashe, W'. F., Jr. and L. B. Roberts, "Experimental Human Burns," War Med., 7: 82-83, 1945.

70. Brooks, J. F., E. I. Evans, W. T. Ham, Jr. and J. D. Reid, "The Influence of Extemal Body Radiation on Mortality from Thermal Burns," Ann, Surg., 136: 533-545, 1952.

71. Clapper, W. E. and G. H. Meade, "Radiation Effects on Pneumococcal Infection Produced by Subcutaneous Injection into White Mice," USAEC Report AECU-3267, Lovel ace Foundation for Medical Education and Research, Albuquerque, New Mexico, October 1953 (published in 1957). Also in Proc. Soc. Exper. Biol. E Med., 86: 420-422, 1954.

72. Clapper, W. E. and G. H. Meade; "The Effect of Foreign Body Particles on Infections in Mice," USAEC Report AECU-3272, Lovelace Foundation for Medical Education and Research, Albuquerque, New Mexico, August 15, $195^{35}$ (published in 1957).

73. Berlin, Nathaniel I., "Military Aspects of the Biological Effects of Radiation," AFSWP-611, Headquarters, Armed Forces Special Weapons Project, Washington 25, D. C., November 9, 1956.

74. Sanford, J. P. and H. E. Noyes, "Effect of Total Body X-Irradiation on the Susceptibility of Mice to Escherichia Coli Endotoxin," WRAIR-200-56, Walter Reed Army Institute of Research, W'ashington 12, D. C., December 1956.

75. Clemedson, Carl-Johan and Arne Nelson, "The Effects of a High Explosive Blast in Mice with Radiation Injury," Acta Radiologica, 47: 79-85, January 1957.

76. Clemedson, Carl-Johan and Arne Nelson, "Effects of Combined Whole Body Roentgen Irradiation and High Explosive Blast Injury in Mice," Acta Radiologica, 43: 161-172, 1955.

77. Brown, S. O., "The Study of Wound, Burn and Fracture Healing in the Albino Rat and Mouse Subjected to Continuous Irradiations of Different Intensities," AD 212170, Texas Engineering Experiment Station and Texas A \& M Research Foundation, College Station, Texas, February 24, 1959.

78. Taylor, J. W., "X-Irradiation and Acceleration Stress," United States Naval Air Development Center, March 1, 1960.

79. Rusanov, S., Yu. Drugov, I. Bezdenezhnykh and K. Baryshnikov, "Combined Combat Injuries," JPRS: 5048, OTS: 60-11, 949, Office of Technical Services, U. S. Department of Commerce, Washington 25, D. C., July 14, 1960.

80. Shamov, V. N. (Professor), editor, "Ranewiya Cherepa i qolovnogo Mozga priostroy luchevoy bolenzni (Lesions of the Skull and Brain in Acute Radiation Sickness)," Lenigrad, 1962, pp 119-134. Available under the title of "Conclusion from: Lesions of the Skull and Brain in Acute Radiation Sickness - USSR, JPRS Document 15,002 (Joint Publications Res earch Service), U. S. Department of Commerce, Office of Technical Services, Joint Publications Research Service, Building T-30, Ohio Drive and Independence Ave., S. W., Washington 25, D. $C$.

81. Veel, J. V. and W. J. Schull, "The Effects of Exposure to the Atomic Bombs on Pregnancy Determination in Hiroshima and Nagasaki," Atomic Bomb Casualty Commission Publication No. 461, U. S. National Academy of Sciences, National Research Council, Washington 25, D. C., 1956. 
82. Arakawa, E. T., "Radiation Dosimetry in Hiroshima and Nagasaki Atomic Bomb Survivors," Atomic Bomb Casualty Commission Technical Report 14-59, U. S. National Academy of Sciences, National Research Council in cooperation with the Japanese National Institute of Health, Washington 25, D. C. (undated).

83. Arakawa, E. T., "Radiation Dosimetry in Iliroshima and Nagasaki Atomic Bomb Survivors," New Engl. J. Med., 263: 488-493, 1960.

84. Higashimura, T., Y. Ichikawa and T. Sidei, "Dosimetry of Atomic Bomb Radiation in Hiroshima by Thermoluminescence of Roof Tiles," Science, 139: 1284-85, 1963.

85. Auxier, J. A., "Dosimetry Studies for Hiroshima and Nagasaki," presented before the Eighth Annual Meeting of the Health Physics Society, June 11, 1963, New York City, N. Y.

86. Haywood, F. F., "Spatial Distribution of Dose in Air over Ground Geom etry," presented before the Eighth Annual Meeting of the Health Physics Society, June 11, 1963, New York City, N. Y.

87. Thorngate, J. H., "Operation Bren - Spectrometry Studies," presented by F. Saunders before the Eighth Annual Meeting of the Health Physics Society, June 11, 1963, New York City, N. Y. 